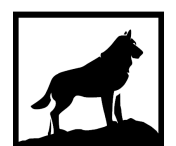

Michigan Technological

1 в 8 5 University
Michigan Technological University Digital Commons @ Michigan Tech

SEVERE THUNDERSTORMS CREATE WINDFALL OF OPPORTUNITY FOR ECOSYSTEM-BASED MANAGEMENT OF MIXED NORTHERN HARDWOODS

Elizabeth Montgomery Barnes

Michigan Technological University

Copyright 2020 Elizabeth Montgomery Barnes

Recommended Citation

Barnes, Elizabeth Montgomery, "SEVERE THUNDERSTORMS CREATE WINDFALL OF OPPORTUNITY FOR ECOSYSTEM-BASED MANAGEMENT OF MIXED NORTHERN HARDWOODS", Open Access Dissertation, Michigan Technological University, 2020.

https://doi.org/10.37099/mtu.dc.etdr/1039

Follow this and additional works at: https://digitalcommons.mtu.edu/etdr

Part of the Other Forestry and Forest Sciences Commons 


\title{
SEVERE THUNDERSTORMS CREATE WINDFALL OF OPPORTUNITY FOR ECOSYSTEM- BASED MANAGEMENT OF MIXED NORTHERN HARDWOODS
}

\author{
By \\ Elizabeth M. Barnes \\ A DISSERTATION \\ Submitted in partial fulfillment of the requirements for the degree of \\ DOCTOR OF PHILOSOPHY \\ In Forest Science
}

MICHIGAN TECHNOLOGICAL UNIVERSITY

2020

@ 2020 Elizabeth M. Barnes 
This dissertation has been approved in partial fulfillment of the requirements for the Degree of DOCTOR OF PHILOSOPHY in Forest Science.

College of Forest Resources and Environmental Science

Dissertation Advisor: Dr. Andrew J Burton

Committee Member: Dr. Yvette Dickinson

Committee Member: Dr. Rupali Datta

Committee Member: Dr. Curtis Edson

College Dean: Dr. Andrew Storer 


\section{Table of Contents}
Abstract
t...
1 Introduction
1.1 Natural disturbance and succession in mixed northern hardwoods ...................... 7
1.2 Storm frequency and intensity in the Great Lakes region ...................................... 8
1.3 Ecosystem-based management of mixed northern hardwoods............................... 10

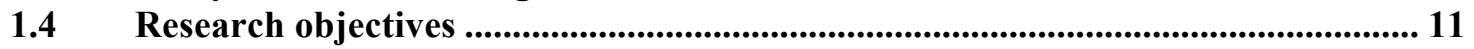

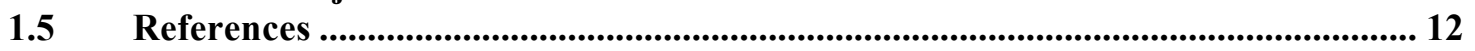

2 Single tree selection timber harvests mediate canopy gap creation by wind disturbance in second growth mixed northern

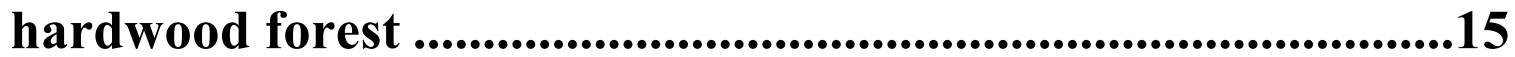

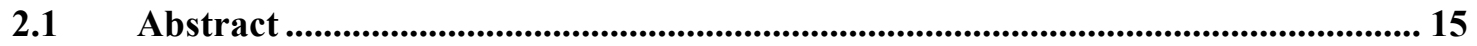

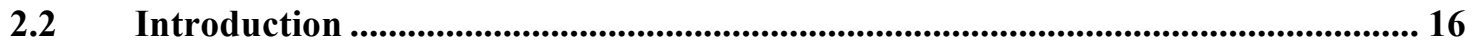

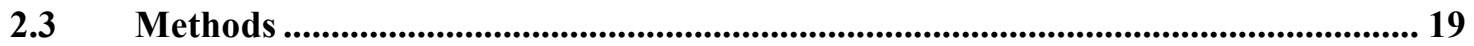

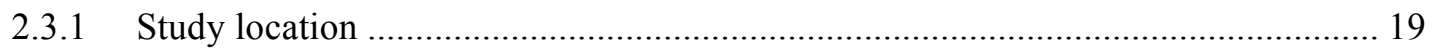

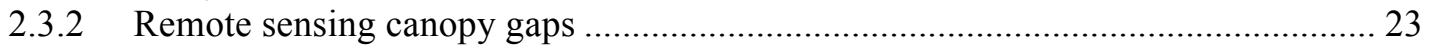

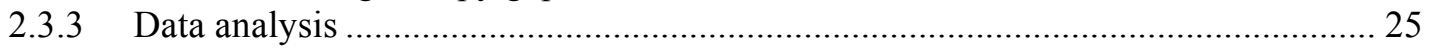

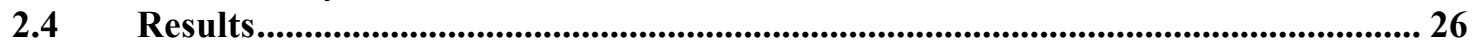

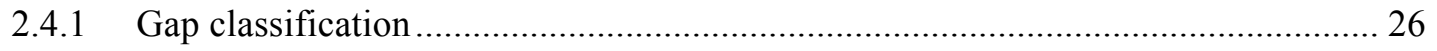

2.4.2 Canopy gap morphology in primary and second growth northern hardwoods ........ 27

2.4.3 Effects of stands management and storm disturbance on gap morphology ............. 29

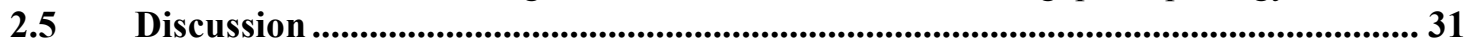

2.6 Implications for ecosystem-based management ............................................... 33

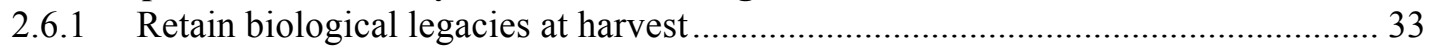

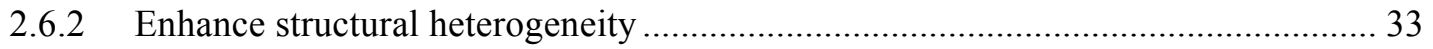

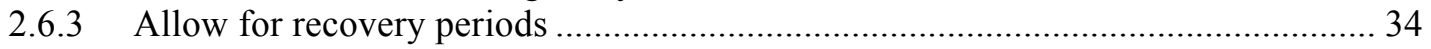

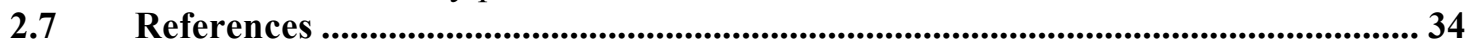

3 Northern hardwood and hemlock seedling bank response to storm disturbance and single tree selection harvest in the southern Keweenaw Peninsula, Michigan .................................38

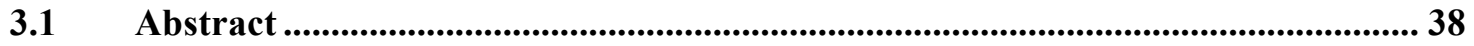

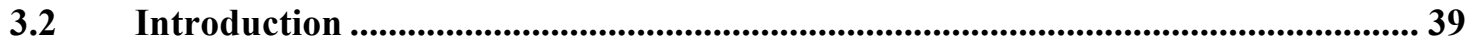

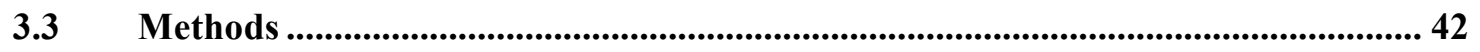

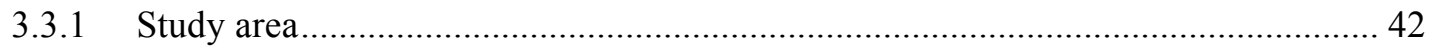

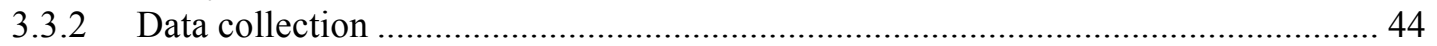

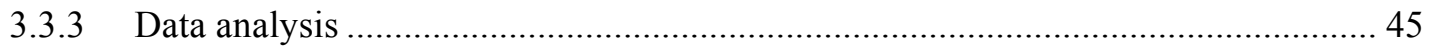

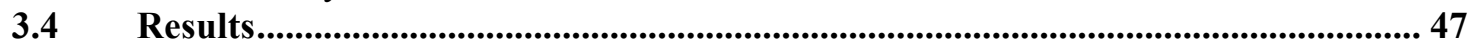

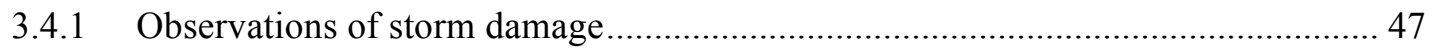

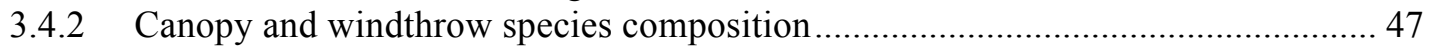

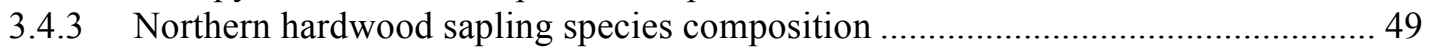

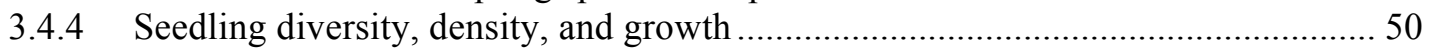

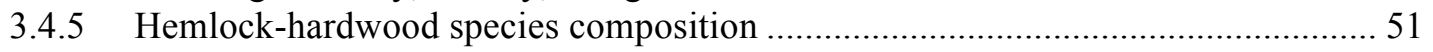




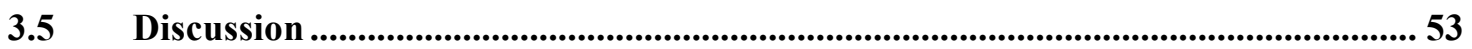

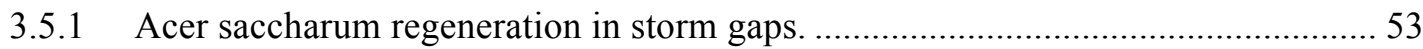

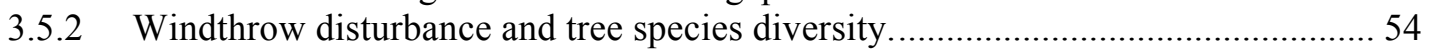

3.6 Implications for ecosystem-based management ................................................... 56

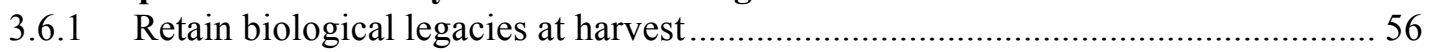

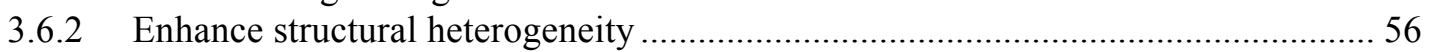

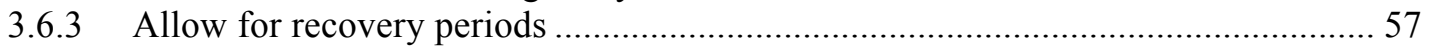

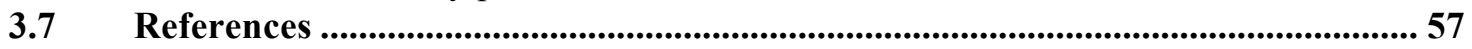

4 Observations of light, microclimate, and coarse woody debris volumes in wind-formed gaps in Acer saccharum hardwoods with and without single tree selection ...................61

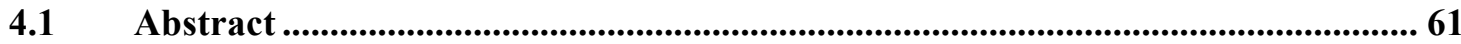

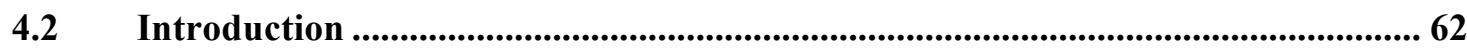

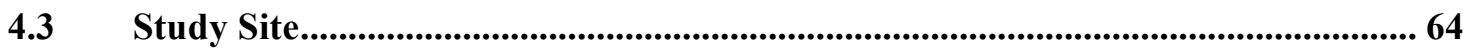

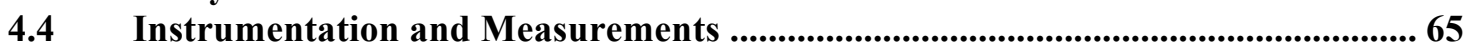

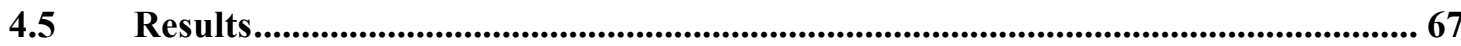

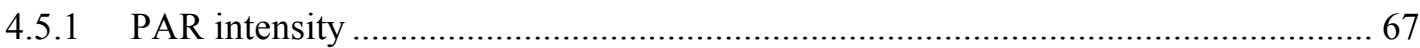

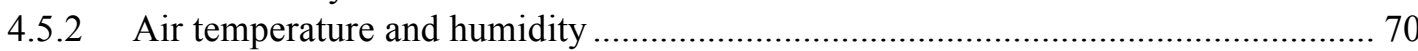

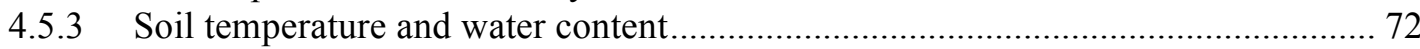

4.5.4 Coarse woody debris in wind-formed gaps and forest interior with and without prior

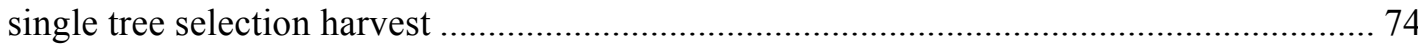

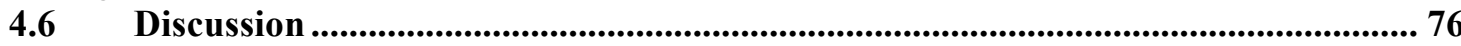

4.7 Implications for ecosystem-based management ....................................................... 77

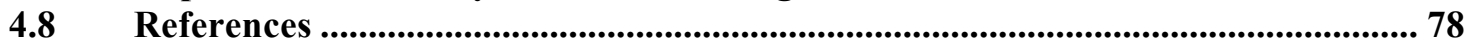

\section{Estimating carbon transfers from decomposing coarse-} wood into soil storage in Nantahala, Chippewa, and Angeles

National Forests for three tree species .....................................81

5.1

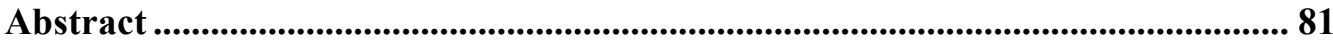

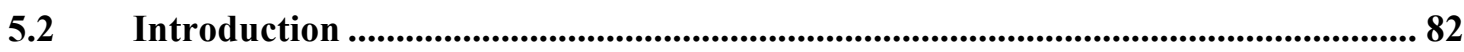

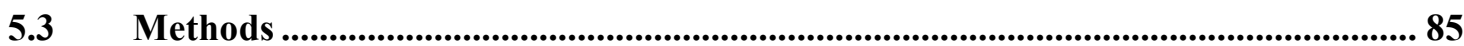

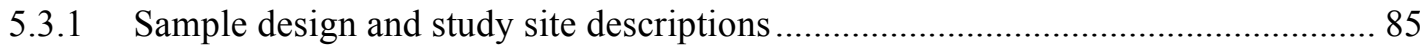

5.3.2 Two-endpoint mixing model estimation of \% soil $\mathrm{C}$ derived from $\log$................... 88

5.3.3 Estimation of log carbon transferred to soil, retained in log, and unaccounted....... 90

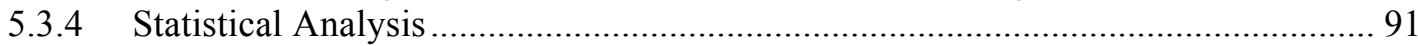

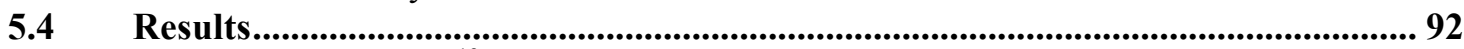

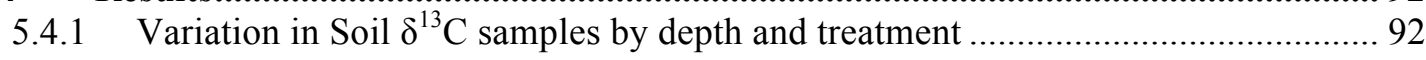

5.4.2 Log decay and \% soil $\mathrm{C}$ derived from $\log$ by site and species............................... 95

5.4.3 Proportions of $\log$ carbon transferred to soil, retained in $\log$, and unaccounted for by

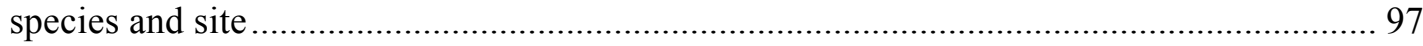

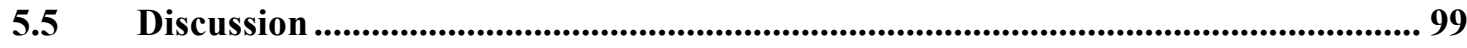

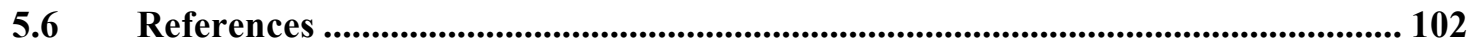

6 Conclusion .................................................................105

6.1 References ........................................................................................................................ 108 


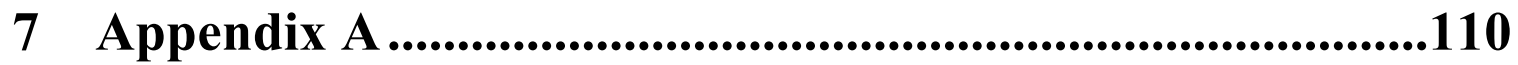

8 Appendix B .....................................................................................113 


\section{Acknowledgements}

There are many people to thank for making this thesis possible. Foremost, my advisor Andrew J. Burton for bringing me to the College of Forest Resources and Environmental Sciences in the beautiful wilderness of the Upper Peninsula, for providing material equipment to carry out field research, and for being an exemplar ecologist. Among tall trees, saplings reach higher. Each of my committee members Drs. Curtis Edson, Yvette Dickinson, and Rupali Datta influenced my understanding of larger forest systems and research techniques by flying drones, attending forestry conferences, and sharing new scientific papers with me. My field assistants Katherine Schneider and Anna DeBraber helped me in identifying trees, counting seedlings, navigating to research plots deep in the woods and relishing in the adorableness of mushrooms. I am grateful to Brad Carlson, unit manager of the Michigan Department of Natural Resources Baraga Forest Resource Division, for his guidance on local stand management practices and research permit requirements. Receiving a Finishing Fellowship from the Graduate Dean Awards Advisory Panel at Michigan Technological University allowed me to complete this dissertation on schedule.

My deepest gratitude lies with my dear husband Lewis and our girls Belle Aeshna (dragonfly) and Frances Aella (storm). Together, as a grove we sway in the wind, shelter the gale, and soak in the sun. And to Keith, Michele, and Katie Montgomery who raised me from seed to sprout. 


\section{Abstract}

The regeneration and reorganization of organisms and their habitat postdisturbance is a primary mechanism by which ecosystems maintain functionality in a changing environment. This adaptation to disturbance lends dynamism and resiliency to landscapes. Yet, the $20^{\text {th }}$ century was marked by an alarming loss of global biodiversity, pointing to the likelihood that the rate of ecological disturbance generated by human systems today is either too frequent or too intense to be beneficial to ecosystems, and rather poses a risk to ecosystem functionality and the carrying capacity of Earth systems. Compounding these risks is high uncertainty regarding the potential for stronger, more frequent occurrences of natural disturbances as the planet's atmosphere warms. Observing and documenting forest responses to natural disturbances provides opportunity to adapt conventional natural resources management to ecosystem-based management.

The objective of this study was to document forest response to a severe thunderstorm disturbance in mixed northern hardwoods, and to assess the effects of single tree selection harvest on gap opening and community succession in maple (Acer saccharum) dominated stands. For this research, I measured forest canopy response to intermediate storm disturbance using aerial imagery and compared gap morphology of northern hardwood forests across a spectrum of prior human disturbance (primary old growth, unmanaged second growth, and working second growth timber stands). This research provides evidence that single tree selection harvest in second growth forests creates more open canopy than in old growth forest, but gaps are smaller, more frequently distributed, and close rapidly. Severe thunderstorm disturbance did not increase mean gap size in stands with recent single tree selection harvest, indicating this harvest method effectively replaces storm damage as the primary disturbance mechanism the forest depends on for gap regeneration. I surveyed storm damage and seedling regeneration in 14 maple-basswood storm gaps and found basswood (Tilia americana) to be especially vulnerable to tree fall, robust sugar maple regeneration at all sites, and the potential origination for a yellow birch (Betula alleghaniensis) grove where single tree selection and natural wind disturbance coincided. I monitored microsite climate and coarse wood 
mass and volume in a subset of gaps and forest interior locations and found evidence that Acer seedlings outcompeted other species across a wide range of understory light availability. Thunderstorm disturbance resulted in the deposition of an immense volume of coarse woody debris in gap habitats. Finally, I used stable isotopes to quantify the retention of carbon $(\mathrm{C})$ in coarse woody debris and the proportion transferred to soil after a hypothetical treefall disturbance. My research indicates up to $10 \%$ of $\log \mathrm{C}$ transferred to soil after six years decomposition, but $\mathrm{C}$ pathways were highly variable across sites.

Findings detailed in the following chapters support the conclusion that single tree selection management of second growth maple-basswood stands is effective in promoting robust Acer seedling regeneration in the western Upper Peninsula. Single tree selection was also found to moderately improve species richness among seedlings compared to unmanaged second growth, likely due to greater canopy richness. However, seedling species evenness was poor across second growth stands regardless of management or storm disturbance. These results emphasize the importance of adapting ecosystem-based management practices within single tree selection methods. Maximizing the retention of diverse canopy tree species as seed trees can facilitate more diverse regeneration in mixed northern hardwood timber stands. Cutting larger, less frequent gaps would better mimic canopy-gap mosaics of old growth forest, and extend the time period of elevated light availability to foster in-gap regrowth and recruitment. In storm gaps, as the fallen trees decompose new substrates will be available for seed germination and may improve community recruitment over time. In unmanaged second-growth hardwood stands with low canopy diversity, planting may be necessary to improve community diversity, and storm gaps provide light-rich environments where such attempts may be most successful. 


\section{Introduction}

\subsection{Natural disturbance and succession in mixed northern hardwoods}

The outward influence of species on their habitat bears consequences for succeeding phases, and in a given habitat this process generates predictable patterns of plant community development over space and time (Dureau de la Malle 1825; Clements 1936; Cowles 1911; Thoreau 1860; West et al. 1981). In temperate or hemiboreal forest types, ecological feedback loops between plant and animal species drive habitat succession. In aspen-spruce forests, for example, stand mortality initiated by spruce budworm (Choristoneura sp.) is followed by early successional aspen regeneration, which is eventually recolonized by shade-tolerant spruce and fir. However, many hemiboreal forest types may not follow preordained succession as it is commonly defined, given the region's harsh winters and drought-prone summers paired with the stochastic nature of fire, wind, and human disturbance and cyclic patterns of browse pressure (Pastor and Mladenoff 1992). The inclusion of red oak (Quercus rubra) and black cherry (Prunus serotina) in mid-successional mixed hardwood forests of the western Upper Peninsula today, for example, may be due to past fires that accompanied intensive logging during the lumber era (Burger and Kotar 2003). Without disturbance repetition, and without ecosystem-based management intervention, these species may become less abundant in mesic northern hardwoods over time.

For sugar maple dominated forests, found on warm mesic sites throughout the western Upper Peninsula along a southern boundary of the global boreal forest, community succession is variable by soil characteristics. On sandy dry-mesic sites with poor to medium nutrient soils, sugar maple is anticipated to form a climax community with red maple (Acer rubrum) and balsam fir (Abies balsamea), white pine (Pinus strobus) may be present. Dry mesic to mesic loamy soils with poor to medium soils foster a more diverse climax community, with sugar and red maples, yellow birch (Betula alleghaniensis), balsam fir, eastern hemlock (Tsuga canadensis) and white pine. Medium 
to rich nutrient soils are highly productive and contain a diverse in mid-successional community of maple, red oak, black cherry, white pine, white ash (Fraxinus americana), basswood, yellow birch, hemlock, and balsam fir, succeeding to sugar maple, hemlock, and yellow birch without significant disturbance. Once established as a canopy dominant sugar maple can form a self-propagating community due to high shade tolerance and high nutrient leaf litter. In temperate deciduous forests such as sugar maple habitat, the influence of storm and wind disturbance and the following gap-filling is a major determinant in stand structure and species composition (Jones 1945). This Aeolian process maintains biodiversity and has subsequent benefits to forest health and resiliency (Pickett and White 1985). Significant disturbance would be required to shift the species composition of sugar maple stands, which form one of the most productive ecosystems in its range.

\subsection{Storm frequency and intensity in the Great Lakes region}

The most severe thunderstorms on Earth occur in the central and eastern United States due to convective energy patterns and shear wind strength (Doswell 2001; Brooks et al. 2003). Rising temperatures on the ground can cause atmospheric instability by lifting warm air masses towards the upper troposphere where they rapidly cool and contract, leaving a vacuum to be filled by cumulus clouds with the potential for thunderstorms. Tumultuous winds associated with unstable air masses can also cause wildfires to burn intensely and erratically. Despite water vapor comprising less than $4 \%$ of atmospheric gases, it wields immense influence on storm systems, ecosystems, and human civilization. Without major elevation changes, the primary process in forming rain droplets or snow crystals is turbulence within clouds melding together small droplets into larger and larger condensates until their weight is no longer supported in the cloud. The importance of a condensation nucleus, provided by fine particles such as soil, soot, or salt, to the formation of precipitation is becoming more widely accepted (Ludlum 1991).

The weather at a given location and time in the Great Lakes region may be influenced by three or more powerful airstreams crossing the continent with air, water, gasses and particulates from thousands of miles away. In addition, local conditions can 
also incite air mass or convective thunderstorms. The jet stream bares particular influence on the weather and climate of western Upper Peninsula and surrounding areas, bringing high speed westerly winds along the narrow isotherm between colder northern and warmer southern regions. The Great Lakes themselves heavily influence regional weather patterns, by reducing maximum air temperatures and increasing winter precipitation. The cool waters of Lake Superior reduce convective heating of air masses and act as a stabilizing force (Scott and Huff 1996). Current research suggests that Lake Superior is rapidly warming, driven in part by reduced ice cover (Austin and Coleman 2007), which could potentially erode its effectiveness as weather stabilizer, with strong implications for more frequent or intense local storm systems.

Global warming models suggest in the central-eastern United States only the most severe storms will be more frequent as polar wind shears will be weaker but updrafts from convective heating may be stronger (Del Genio 2007; Brooks 2013). Lightning striking, which is fed in part by nitrous gases, ozone, and temperature conditions may increase by $10 \%$ per one degree of warming (Price 2009). Another consideration is the diurnal nature of climate warming; warming is greater at night as has been evidenced by nighttime minimum temperature rising disproportionately to daytime maximum (Dessens 1995). As such, the 'off' switch to a thunderstorm in the form of nighttime cooling may be weakened or delayed. Alternatively, nighttime warming may reduce diurnal gradients of air masses and increase tropospheric stability. This could potentially inhibit storm production, but also prolong storms once formed.

It is well established that forests affect weather patterns, i.e. most famously the phenomena of rainforests making their own rainfall (Wright et al. 2017). New ecometerology research is underway to measure the influence of forests in northern Wisconsin on regional weather patterns (Desai et al. 2018). Forests indirectly influence climate by mediating the amount of the greenhouse gas carbon dioxide in the atmosphere. Forests are a major long-term storage facility for earth's carbon, holding over 1,100 billion tons of carbon globally (Dixon et al. 1994), having exchanged carbon with the atmosphere for over 300 million years of growth and development. Contemporary management of forests for high ecological productivity is a key climate change mitigation 
strategy as the greenhouse effect of carbon dioxide is abated by forests that sequester net carbon from the atmosphere in woody biomass and debris, and soils (Kirby and Potvin 2007).

\subsection{Ecosystem-based management of mixed northern hardwoods}

Ecosystem-based management is critical to sustain or re-establish diverse and productive forest ecosystems. Considering natural disturbances, such as wind damage to canopy in severe thunderstorm events, is a key component to ecosystem-based management of natural resources and landscapes for two primary reasons. First, ecological processes found to promote structural and compositional diversity postdisturbance can be stimulated artificially by management activities that mimic natural disturbance. For instance, cutting that creates gap sizes similar to those created by ongoing storm damage, or prescribed burning to stratify serotinous seeds. Second, forest management activities may alter forest responses to natural disturbance, by altering stand demographics or density. The research presented in this dissertation seeks to both monitor the role of severe thunderstorm disturbance on forest structure and composition, as well as assess if single tree selection practices mediate forest responses to storm disturbance.

Single tree selection is the predominant harvest type in sugar maple dominated northern mixed hardwoods managed by the Michigan Department of Natural Resources. This strategy manages for the 'best tree in place' by removing trees competing with croptrees thereby encouraging their growth. Residual basal area is typically $80 \mathrm{ft}^{2} / \mathrm{ac}$ and stands are re-entered at a 10-year minimum cutting interval. This method of harvest results in small gap disturbance patterns while maintaining contiguous forest cover. Small gaps foster propagation by sugar maple, a highly shade-tolerant tree. In contrast to singe tree selection, storm disturbance of forest canopy is driven by strong down drafting winds, with tree mortality typically occurring in small groups or groves of trees. Another difference between natural storm disturbed and thinned forest is that canopy gaps from 
storm are lush with large downed dead wood, and harvest gaps are not. Over time, down dead wood logs and branches decompose, and in addition to sheltering wildlife and sequestering carbon, provide substrate for temporally-staggered tree species recruitment.

While ecologically-based timber harvest prescriptions seek to mimic natural disturbance, they do not replace natural disturbances which are on-going. Monitoring the effect of harvest on post-storm tree mortality, canopy openness, and stand succession is a key component of efficiently managing northern timberlands to not only fulfill demand for high quality timber, but also to manage for stand diversity. To manage forests for productivity and diversity, natural disturbances provide a blue-print for processes of stand regrowth and recruitment. Natural disturbances stimulate key ecological processes within forest development that enhance or modify structural heterogeneity and species composition. Structural heterogeneity, provided by multiple age and size classes of trees, understory vegetation, snags and logs are important to wildlife and forest diversity. Species composition drives forest productivity, functional redundancy and ecosystem resilience to environmental change by providing the biological material for adaptation.

Ecosystem based management of mixed northern hardwoods is a developing field of knowledge. Three principles of ecological forestry developed by Frankin, Mitchell and Palik (2007) are retaining biological legacies at harvest, applying intermediate treatments that enhance structural heterogeneity, and allowing for recovery periods. Each chapter in this dissertation touches on one element of forest response to single tree selection harvest or storm disturbances, or both. The implications of this research for ecosystem-based management of mixed northern hardwoods is presented at the end of each chapter.

\subsection{Research objectives}

The goal of this research is to observe natural gap creation associated with severe storms, subsequent release and recruitment from the seedling layer, and factors controlling the fate of coarse woody debris carbon created by windfall to better inform ecosystem-based management of mixed northern hardwoods. To examine these issues, in Chapter 2 remote sensing techniques are used to measure canopy gaps created in a severe wind disturbance affecting secondary forests with different chronologies of timber 
harvest, and to compare second growth hardwood gap morphology to baseline conditions found in primary forest habitat of the Porcupine Mountains Wilderness. In Chapter 3, regeneration and recruitment were investigated in fourteen storm gaps, and trends in diversity were compared across stand-level characteristics and management history. In

Chapter 4, variability in microclimatic conditions and coarse woody debris volumes of four storm gaps were measured in adjacent second growth stands managed with and without single tree selection timber harvest. Each of these three chapters directly addresses the subject of canopy gaps and species diversity. Results from Chapters 2, 3, and 4 indicate that Acer saccharum strongly dominates the seedling layer and that intermediate storm disturbance did not increase species diversity, regardless of management history. Based on these results, in my conclusion, I suggest recommendations for adapting single tree selection to foster greater diversity among seedling regeneration based on observations of natural response to thunderstorms. Chapter 5 examines how climatic variation and wood species influences movement of CWD carbon to soil and implications for forest management intended to sequester carbon and for our ability to model ecosystem carbon cycling in a future that might include enhanced levels of windfall and other disturbances that create CWD.

\subsection{References}

Austin, J. A., and S.M. Colman. 2007. Lake Superior summer water temperatures are increasing more rapidly than regional air temperatures: A positive ice-albedo feedback, Geophys. Res. Lett., 34.

Brewer, R. and P.G. Merritt. 1978. Wind throw and tee replacement in a climax maplebeech forest. Oikos, 30: 149-152.

Brooks, H.E. 2013. Severe thunderstorms and climate change. Atmospheric Research, 123: $129-138$.

Brooks, H. E., J. W. Lee, and J. P. Craven. 2003. The spatial distribution of severe thunderstorm and tornado environments from global reanalysis data, Atmos. Res., 67-68: 73-94. 
Burger, T.L. and J. Kotar. 2003. A guide to forest communities and habitat types of Michigan. University of Wisconsin, Madison.

Clements F.E. 1936. Nature and structure of the climax. Journal of Ecology 24(1): 252284.

Cowles, H.C. 1911. The causes of vegetative cycles. Botanical Gazette 51(3): 161-183.

Del Genio, A. D., M.S. Yao, and J. Jonas. 2007. Will moist convection be stronger in a warmer climate? Geophys. Res. Lett., 34(16).

Desai, A., S. Metzger, G. Petty, M. Schwartz, P. Townsend. 2018. Chequamegon Heterogenous Ecosystem Energy-balance Study Enabled by a High-density Extensive Array of Detectors ('CHEESEHEAD'). Proposal to National Science Foundation.

Dessens, J. 1995. Severe convective weather in the context of a nighttime global warming. Geophys. Res. Lett., 22(10): 1241-1244.

Dixon, R.K., A.M. Solomon, S. Brown, R.A. Houghton, M.C. Texier, and J. Wisniewski. 1994.Carbon pools and flux of global forest ecosystems. Science, 14: 185-190.

Doswell, C. A.III. 2001. Severe Convective Storms, Meteorol. Monogr. Ser., vol. 28(50), 570 pp., Am. Meteorol. Soc., Boston, Mass.

Dureau de la Malle, A. 1825. Memoir on alternation or on alternative succession in the reproduction of plant species living in a community - is it a general law of nature? Annales des Sciences Naturelles, 5: 353-381.

Foster, D.R. 1988. Species and stand response to catastrophic wind in central New England, U.S.A. Journal Of Ecology, 76(1): 135-151

Franklin, J.F., R.J. Mitchell, B.J. Palik. 2007. Natural Disturbance And Stand Development Principles For Ecological Forestry.United States Department Of Agriculture Forest Service Northern Research Station General Technical Report NRS-19.

Jones, E.W. 1945 The structure and reproduction of the virgin forests of the north Temperate zone. New Phytol., 44: 130-148.

Kirby, K. And C. Potvin. 2007. Variation In Carbon Storage Among Tree Species: Implications For The Management Of A Small-Scale Carbon Sink Project. Forest Ecology And Management, 246: 208-221.

Ludlum, D.M. 1991. The Audubon Society Field Guide to North American Weather. 
New York: Alfred A. Knopf, Inc.

Pastor, J., and D.J. Mladenoff. 1992. THe southern boreal-northern hardwood forest border. In: Shugart, H.H., R. Leemans, and G.B. Bonan (eds.) A Systems Analysis of the Global Boreal Forest. Cambridge University Press.

Pickett, S.T.A., P.S. White, eds. 1985. The Ecology of Natural Disturbance and Patch Dynamics. New York: Academic Press.

Price, C. 2009. Thunderstorms, Lightning and Climate Change. In: Betz H.D., Schumann U., Laroche P. (eds) Lightning: Principles, Instruments and Applications. Springer, Dordrech.

Scott, R.W. and F.A. Huff. 1996. Impacts of the Great Lakes on Regional Climate Conditions. Great Lakes Res, 22(4): 845-863.

Smith, D. M. 1996. The practice of silviculture. New York: Wiley.

Thoreau, H.D. 1860. The succession of forest trees. Essay first published in New York Weekly Tribune 13 December 1860.

West, D.C., H.H. Shugart, and D.B. Botkin (eds). 1981. Forest Succession Concepts and Application. New York City: Springer-Verlag.

Wilkinson D. 1999. The Disturbing History Of Intermediate Disturbance. Oikos. 84 (1): $145-147$.

Wright, J.S., R. Fu, J. Worden, S. Chakraborty, N. Clinton, C. Risi. W. Sun, and L. Yin, 2017. Rainforest-initiated wet season onset over the southern Amazon. PNAS, 114(32): 8481-8486. 


\section{Single tree selection timber harvests mediate canopy gap creation by wind disturbance in second growth mixed northern hardwood forest}

\subsection{Abstract}

Restoring old growth characteristics in second growth forests can benefit wildlife, environmental quality, stand productivity and timber yield. Canopy disturbance, tree fall, and gap creation is a key component of high structural complexity in old growth forests. This study compares canopy openness and gap morphology in primary old growth forest to second growth mixed hardwoods managed for timber and affected by severe thunderstorms occurring on July 2016, with winds of up to $150 \mathrm{~km}$ per hour that created multiple windfall gaps of varying sizes. Canopy gaps larger than $20 \mathrm{~m}^{2}$ were located and measured by maximum likelihood supervised classification of year 2014 and 2016 National Agriculture Imagery Program (N.A.I.P.) aerial images in ArcMAP software. Second growth forests managed for timber by single tree selection methods had more open canopy with more frequent and complex gaps than old growth forest. The vast majority of canopy gaps in both forest types were less than $150 \mathrm{~m}^{2}$ in size. Spatial regression was applied to test the effect of time since harvest, tree diameter, species richness, \% sugar maple (Acer saccharum), mean hill slope, elevation, and available water storage on gap morphology and response to storm disturbance across 46 management units of secondary growth forest. This study found that the timing of single tree selection harvest was important in shaping how forest canopies responded to storm disturbance. Forest stands harvested longer ago had more significant increases in gap size and frequency post-storm than in more recently harvested stands. 


\subsection{Introduction}

The primary mixed conifer-hardwood forest once predominating the Great Lakes region has largely been replaced with second growth forests after rapid deforestation accompanied the westward expansion of Europeans from the late $17^{\text {th }}$ century on. The rapid transformation of the landscape by intensive land clearing decimated natal habitats of keystone mammals and drove the extirpation or endangerment of the gray wolf (Canis lupus), elk (Cervus canadensis), wolverine (Gulo gulo), lynx (Lynx canadensis), and mountain lion (Puma concolor). As the land heals and the first generation of forest regrowth now approaches 90-140 years of age, barring major disturbance, big trees will increasingly shape the natural environment again. Contemporary management of second growth forests for timber can modify the structural characteristic of forest to accelerate or delay the demographic transition to old growth stature (Choi et al. 2007; Fassnacht et al. 2015; Singer and Lorimer 1997). Studying how storm disturbance alters canopy-gap dynamics can inform how single tree selection harvest can be modified to restore the canopy patterns found in primary old growth.

Light availability is a limiting resource beneath the canopy of mature forest and is apportioned by canopy openness and gap morphology, which together advance overstory tree growth and allow for new species recruitment. Gap habitats provide refugia for the establishment of gap-specialist wildlife, understory development and recruitment, and ecological succession (Degen et al. 2005; Pederson et al. 2008). Wind disturbance is regarded as one of the most prolific forces of natural canopy gap dynamics, driving both stand structure and composition in northern hardwoods. Catastrophic blow-downs, creating multi-hectare gaps, are well documented in public land survey records of latesuccessional pre-settlement forests in northern Wisconsin and the Upper Peninsula of Michigan (Canham and Loucks 1984; Schulte and Mladenoff 2005; Zhang et al. 1999). Canopy gaps, such as those surveyed in Public Land Survey Records of the mid 19 century, provide an ecological record of natural disturbance history and indicate localized and regional patterns of tree mortality and canopy-gap dynamics. However, in expansive tracts of mesic northern hardwood forest stands dominated by shade-tolerant sugar maple (Acer saccharum), the rotation period for large-scale catastrophic disturbance may be 1-2 
centuries (Lorimer and Frelich 1994). In these dense forests, the continual creation of smaller gaps, less than 1 ha, by intermediate disturbances such as severe thunderstorms, are less well documented in historical records but are critical for the ontogenesis of gap habitat and the establishment and persistence of tree species diversity.

Windthrow severity and extent in forests is not only a factor of storm event intensity and frequency, but is mediated by landscape ecology and stand conditions (Strutevent et al. 1997; Wilson 1976). Thus, windthrow may play a more or less significant role in forest structure at different times in a forest's development, or spatially across different management regimes. For instance, older trees with larger diameter are increasingly vulnerable to windthrow in northern hardwoods (Everham and Brokaw 1996; Foster 1998; Peterson and Pickett 1991). Further, tree age influences the type of damage that may be sustained in severe winds; for example, older aged trees are more susceptible to uprooting and breakage, which are less common in young $<100$-year-old stands except in very intense winds (Hubert 1918). Also, larger, more densely arranged trees are predicted to result in more secondary treefall; Brewer and Merit (1978) observed that many trees are uprooted by a domino effect, rather than direct impact of wind

The creation of canopy gaps from tree harvest can mimic natural disturbance types across a range of intensity, from single tree mortality to large-scale blow downs. Thinning treatments, crop release, and single tree selection create smaller, more frequent canopy gaps in order to promote the growth of large trees and facilitate new recruitment and greater age class diversity. In turn, manipulating the structural character of forest stands, particularly variation in tree diameter and density, influences natural patterns of canopy openness and gap morphology. Documentation from scientific literature is at times contradictory on whether more or less dense arrangement of trees increases wind damage. In thinned plots, wind loading is significantly higher in the less dense arrangement, as wind is better able to access the sides of individual tree canopies, so that tipping is overall more likely. Growth environment can lead to divergent structural forms and subsequent wind resistance. Wind tunnel and field experiments by Gardiner et al. 1997 found that as tree spacing increases, tree diameter and stability increases, reducing breakage. In contrast, suppressed sugar maple saplings were somewhat thicker trunked 
with greater stability (King 1986). The timing of storm disturbance in relation to management is important to consider. Immediately after thinning residual trees are more susceptible to windthrow, as their smaller root systems do not provide the stability required on the increased wind load their more exposed crowns may receive.

Other studies have found topography and landscape position to be better predictors of wind damage than forest management (Roberts et al. 2007). Faster wind speeds at higher elevations, and limited rooting depth on steep slopes can both influence windthrow vulnerability (Boose et al. 1994). Soil conditions, which are expected to vary both naturally across the landscape as well as across the spectrum of management history, play a critical role in storm vulnerability. When heavy rain accompanies wind, wetness and saturation reduce soil cohesion and shear strength, leading to tree uprooting and tipup (Putz et al. 1983). Windthrow vulnerability also varies by species (Day 1950; Hubert 1918) and sugar maple in particular has been observed to be less susceptible to windthrow than other species such as red maple (Acer rubrum) and northern red oak (Quercus rubra) (Canham et al. 2001). This feature may be a significant advantage in wind-prone topographies.

Timber harvest may increase or decrease the impact of wind disturbance by modifying stand age, health, and tree size distribution and arrangement. However, the effect of single tree selection cutting practices on impacts of wind disturbance and natural canopy opening is not clearly understood. The objective of this study is two-fold: first to document the bilateral effects of a severe summer thunderstorm and previous single tree selection on canopy openness and gap morphology in second growth maple-dominated hardwoods in western Upper Michigan; and second, to compare second growth forest canopy to primary old growth forest gap morphology in the Porcupine Mountains Wilderness State Park. If the morphology of wind gaps in stands managed by single tree selection methods differ significantly from unmanaged second growth or primary old growth gap morphology, it may indicate a divergence from native-ecological processes of gap formation. This comparison of gap morphology sets the context for chapter 3 , in which regeneration patterns across disturbance type and management histories are further explored. 


\subsection{Methods}

\subsubsection{Study location}

The study area comprises 2,250 hectares of primary growth forest at the southern extent of the Porcupine Mountains Wilderness State Park (PMW) and 1,696 hectares of second growth mixed northern hardwoods in central Houghton County (CHC). Both areas are managed under the direction of the Michigan Department of Natural Resources (MI-DNR). The PMW encompasses one of the largest remaining old-growth Laurentian mixed forests, providing a benchmark for northwood forest ecology and succession (46.75 N, -89.70 W) (Figure 1.1). Much of PMW is a National Natural Landmark. To serve as an old growth reference, I delineated a study area at the south-central edge of PMW, comprising primitive mixed hardwood forest with no history of clear cutting or timber harvest.

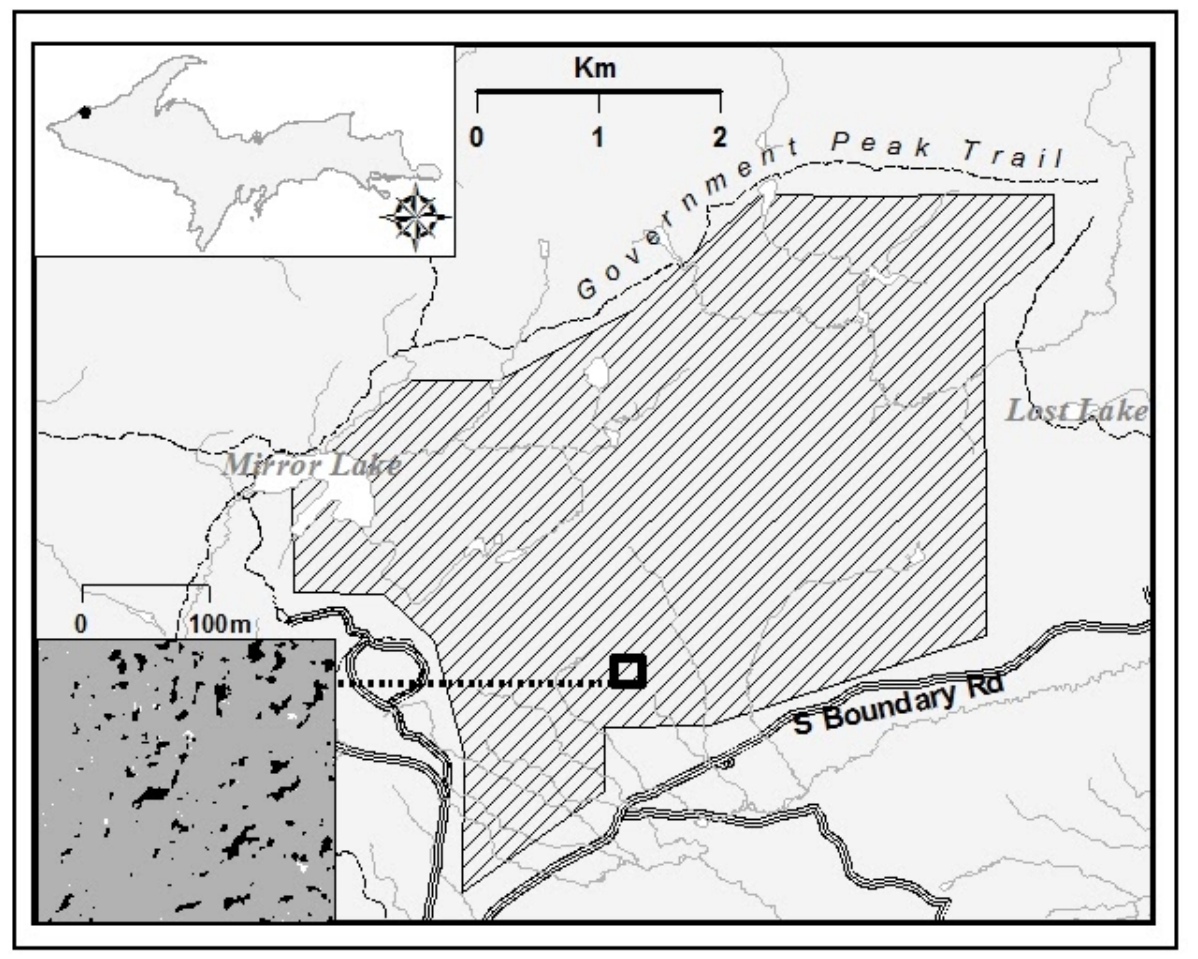

Figure 2.1. Primary northern mixed hardwoods study area in the Porcupine Mountains Wilderness State Park. Insert bottom left: sample of canopy gap classification results 
Eighty kilometers to the East, the CHC study area is located at the southernmost edge of Michigan's Keweenaw Peninsula (46.88 N, -88.85 W) (Figure 1.2). Clear-cut in the late 19th century, dense regeneration created the 90-140 year old mixed northern hardwoods that predominate the landscape and provide critical forest cover for headwater reaches of six Lake Superior Basin rivers, Misery River, Elm River, North and South branches of Bear Creek, Otter River, East Branch Firesteel River, and Sleeping River as well as the Lake Roland and Lake Gerald. The CHC study area is divided into 46 management units stands (Appendix A, Table 1.1). The stands are dominated by sugar maple (35-84\% abundance) or co-dominated by red and sugar maple (28-40\% abundance sugar maple). Contemporary management of the $\mathrm{CHC}$ forest prioritizes timber production; stands are typically entered at a 15-20 year rotation cycles for single tree selection harvest. Two stands included in this study, Twin Lakes State Park, and a longterm forest research site (FCS '5512'), are not currently managed for timber and have not been harvested for more than 50 years. 


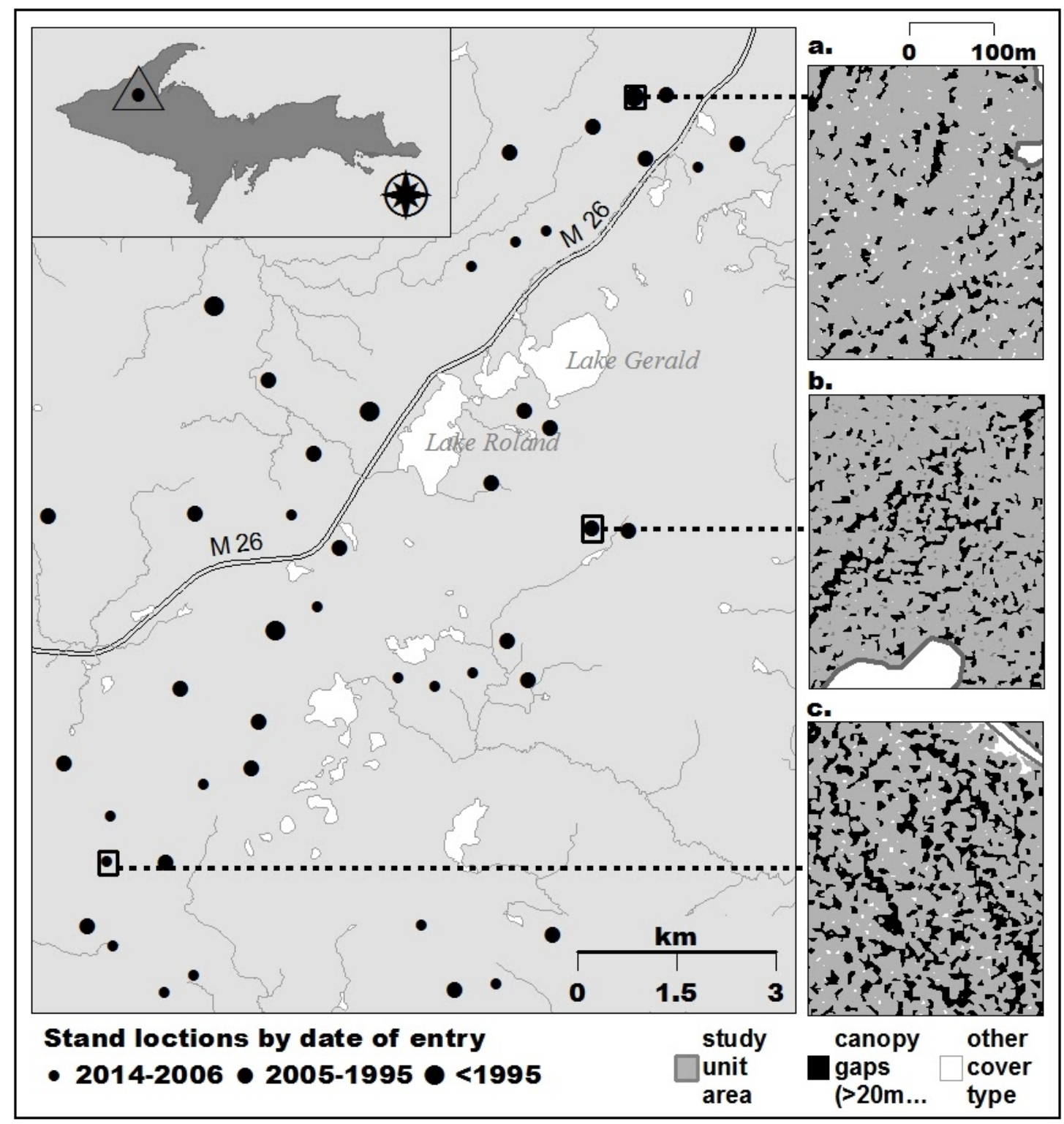

Figure 2.2 Locations of second growth northern mixed hardwood forest study stands ( $\mathrm{n}=$ 46) in central Houghton County, Michigan Department of Natural Resources Baraga Forest Management Unit (Right panel: sample visual of land cover classification in three study stands). 
On 21 July 2016, a significant thunderstorm outbreak moved across the western Upper Peninsula, producing thunderstorms with straight-line winds of up to $150 \mathrm{~km} \mathrm{~h}^{-1}$ and lasting at least 5 minutes (NOAA NWS) (Figure 1.3). Subsequently, the storm resulted in the formation of canopy gaps across the $\mathrm{CHC}$ study area. Multiple occurrences of tree fall were reported by law enforcement, storm trackers, and residents. Coincidently, aerial images of the CHC study area were acquired by N.A.I.P. days after the storm. Severe thunderstorms are a common weather phenomenon in the region.

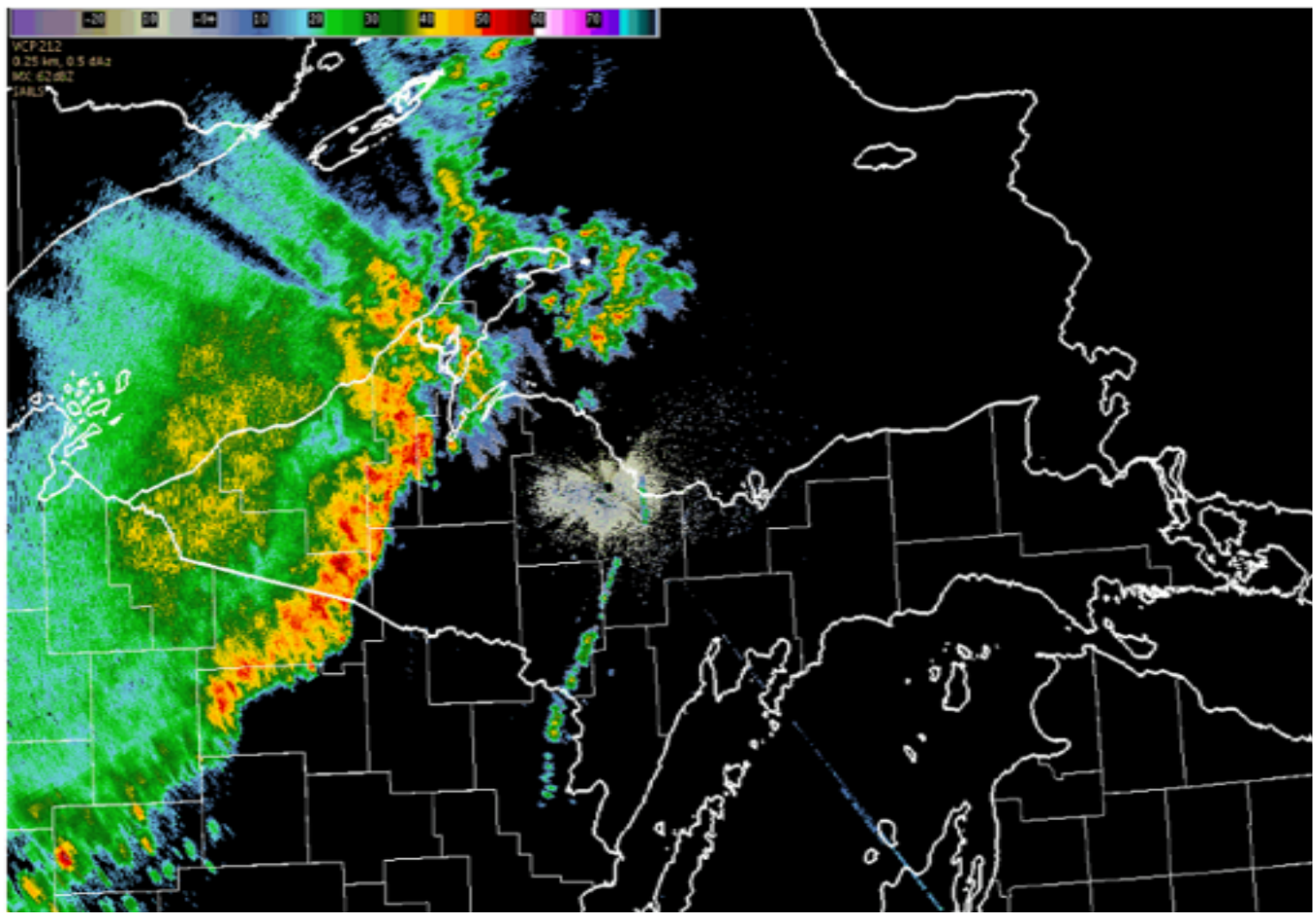

Figure 2.3. Severe thunderstorms moving across Elm River Township, MI, on 21 July, 2016 producing straight-line winds up to $150 \mathrm{~km} \mathrm{~h}^{-1}$ causing extensive treefall, and subsequently, the formation of naturally- disturbed canopy gaps across a wide area of local mesic northern hardwood forests. Source: (weather.gov/mqt/2016-07-

21_severe_winds) 


\subsubsection{Remote sensing canopy gaps}

High resolution (1 meter) N.A.I.P. 4-band true color and near infrared (RGB+) digital ortho-quarter quad image tiles were classified by maximum likelihood supervised classification in ArcMAP software. Imagery of the CHC study area was composed from mosaicked N.A.I.P. images acquired on 6 and 23 September 2014. Imagery of the PMW study area was composed from mosaicked N.A.I.P. images acquired on 6 September and 11 October 2014. Post-storm imagery of CHC was acquired on 23 September 2016; coverage of the PMW study area was not available for year 2016. Horizontal accuracy of N.A.I.P. imagery was $+/-6$ meters true to ground. Additional meta-data information, orthorectification and radiometric adjustment methods are available from USDA-FSAAPFO. Pixel resolution of year 2016 imagery was adjusted from $0.6 \mathrm{~m}$ to a $1.0 \mathrm{~m}$ cell size to match 2014 resolution by nearest neighbor resampling in ArcMAP (v10.6). Nonforested land cover types (barren land, cultivated crops, developed, emergent wetlands, pasture, herbaceous, open water and shrub/scrub) identified by the National Land Cover Database (NLCD) were excluded from study area extents. Major roads and National Wetlands Inventory wetlands were also removed with $6 \mathrm{~m}$ buffers to minimize the occurrence of edge effects and mixed influence pixels.

An accuracy assessment of nine potential classification methods to delineate canopy gaps was first performed as follows: 1) The differentiation of gaps from forest canopy was visually assessed in RGB+ imagery with and without spectral transformations: Simple Ratio (SR), Difference Vegetation Index (DVI), Normalized Difference VI, and Visible Difference VI (see Xue and Bu 2017 for descriptions and equations), 2) Supervised maximum likelihood classification (MLC) and unsupervised (ISO, 3 and 12 classes) techniques were then applied to three best image versions (RGB+, SR, DVI) in ArcMAP software. For MLC, three classes were specified ("canopy" "gap" and "other"). For each classification method, accuracy assessment data points were randomly generated, manually classified, and compared to software-classified output in a confusion matrix. 3) The most accurate image classification techniques (MLC of RGB+ and SR) were then compared for 2014 and 2016 images with another iteration of accuracy assessment points and confusion matrices (Table 1.1). 
Table 2.1. Image classification accuracy assessment work-flow and results

1). Visual assessment of canopy gap definition (2010 sample imagery)

\begin{tabular}{|l|l|l|l|l|l|}
\hline NDVI & VDVI & & DVI & SR & RGB + \\
\hline \multicolumn{2}{|c}{$\downarrow$} \\
\hline \multicolumn{4}{|c|}{$\downarrow$}
\end{tabular}

low definition of canopy gaps

high feature definition

\begin{tabular}{|c|c|c|c|c|}
\hline & \multicolumn{4}{|c|}{ 2). Confusion matrix accuracy assessment results ( $U$, kappa) } \\
\hline & \multicolumn{2}{|c|}{ ISO ( 3 classes) } & ISO (12 classes) & MLC (3 classes) \\
\hline DVI & \multirow{3}{*}{\multicolumn{2}{|c|}{$\begin{array}{l}\text { low definition (N/A) } \\
\text { low definition (N/A) }\end{array}$}} & \multirow{3}{*}{$\begin{array}{l}\text { poor definition }(0.5 \text {, } \\
0.264) \\
\text { fair definition }(0.8,0.643) \\
\text { poor definition }(0.9, \\
0.838)\end{array}$} & low definition (N/A) \\
\hline SR & & & & fair definition $(1.0,1.0)$ \\
\hline \multirow[t]{5}{*}{ RGB+ } & & & & $\begin{array}{c}\text { good definition }(0.9 \\
0.838)\end{array}$ \\
\hline & & & & $\downarrow$ \\
\hline & \multicolumn{4}{|c|}{ 3). 2014 and 2016 sample imagery MLC accuracy assessment results } \\
\hline & $R G B+(2014)$ & $\begin{array}{l}\text { good definition (1.0, } \\
1.0)\end{array}$ & SR (2014) & $\begin{array}{c}\text { fair definition }(0.8, \\
0.667)\end{array}$ \\
\hline & $R G B+(2016)$ & $\begin{array}{l}\text { good definition (1.0, } \\
1.0)\end{array}$ & SR (2016) & low definition (N/A) \\
\hline
\end{tabular}

Maximum likelihood supervised classification of RGB+ imagery was selected as the best performing method. Pixels classified by this method in 2014 and 2016 imagery as canopy gap were converted to polygon features, and spatially joined to each study stand area for each year. Gap polygons measuring less than $20 \mathrm{~m}^{2}$ were excluded from the data sets. All large gap polygons $>500 \mathrm{~m}^{2}$ were visually examined for accurate classification; a small portion of these gaps were re-classified as road edges and removed from the dataset. 
Field surveys were carried out in summer 2017 to ground-truth computerclassified canopy gaps. In DNR stand " $54-12$ ", five transects 140 meters in length and spaced 30 meters apart were traversed perpendicular from the roadside and leading into the forest (Appendix A, Figure 1.1). Canopy gaps were identified along and between survey transects for a census count. Observed gap locations were recorded with a submeter hand-held GPS unit.

\subsubsection{Data analysis}

Gap morphology was described for each of the 46 CHC stands and the PMW study area in terms of: percent canopy openness (total area in gap / total stand area), mean gap size $\left(\mathrm{m}^{2}\right)$, gap frequency (number of gaps / hectare), and gap complexity index $\left(\mathrm{CI}=\right.$ gap perimeter $\left./ 2 *(\pi * \text { gap area })^{\wedge} 0.5\right)$. A complexity rating of 1 indicates a perfect circle, and increasing values denote increasing shape complexity. Differences in gap morphology between $\mathrm{CHC}$ second growth and PMW primary hardwoods was assessed by a one-sample t-test. In CHC, correlation of gap morphology to the following stand characteristics was assessed by ordinary least squares (OLS) regression analysis in ArcMAP: relative abundance sugar maple (\%), mean tree diameter at breast height (D.B.H.), species richness, and years since most recent harvest (2014 - harvest year) (sourced from publicly-accessible MI-DNR geospatial data available from https://gismichigan.opendata.arcgis.com), elevation, slope (10-meter resolution, sourced from the USDA NRCS Geospatial Data Gateway), and available water storage (AWS, 0-100 cm soil depth sourced from NRCS Web Soil Survey). Slope, elevation, and AWS were summarized at the stand-level as area-weighted averages.

Exploratory regression was carried out in ArcMAP prior to OLS to evaluate explanatory models for multicollinearity, standard distribution of residuals, and autocorrelation. OLS models were selected that had non-significant Jacque-Bera, Koenker'sBreusch-Pagan, and Moran's Global I, and for fewest explanatory variables, highest $\mathrm{R}^{2}$, lowest Akaike Information Criterion (AIC), and lowest variance inflation factor. Separate OLS analyses were carried out for 2014 and 2016 gap morphology. A third OLS analysis was carried out to compare the net change $(\Delta)$ in canopy openness, $\Delta$ 
mean gap size, $\Delta$ mean gap frequency, and $\Delta$ mean gap complexity between pre- and post-storm imagery $[\Delta=(2016$ - 2014)/2016]. Significance of gap morphology differences between 2014 and 2016 were also assessed by paired t-test.

\subsection{Results}

\subsubsection{Gap classification}

Across the CHC study area, image classification yielded a total of 28,279 gap polygons $\left(>20 \mathrm{~m}^{2}\right)$ in 2014 and 31,535 in 2016. Across the PMW study area, 24,392 gap polygons $\left(>20 \mathrm{~m}^{2}\right)$ were classified in 2014 imagery. Accuracy of maximum likelihood classification of canopy gaps was $97 \%$ in identifying the 31 storm gaps located by field survey. One canopy gap measuring $>20 \mathrm{~m}^{2}$ during field survey was classified in N.A.I.P. imagery as two smaller gaps, each measuring $<20 \mathrm{~m}^{2}$, and was thus missing from the sample set.

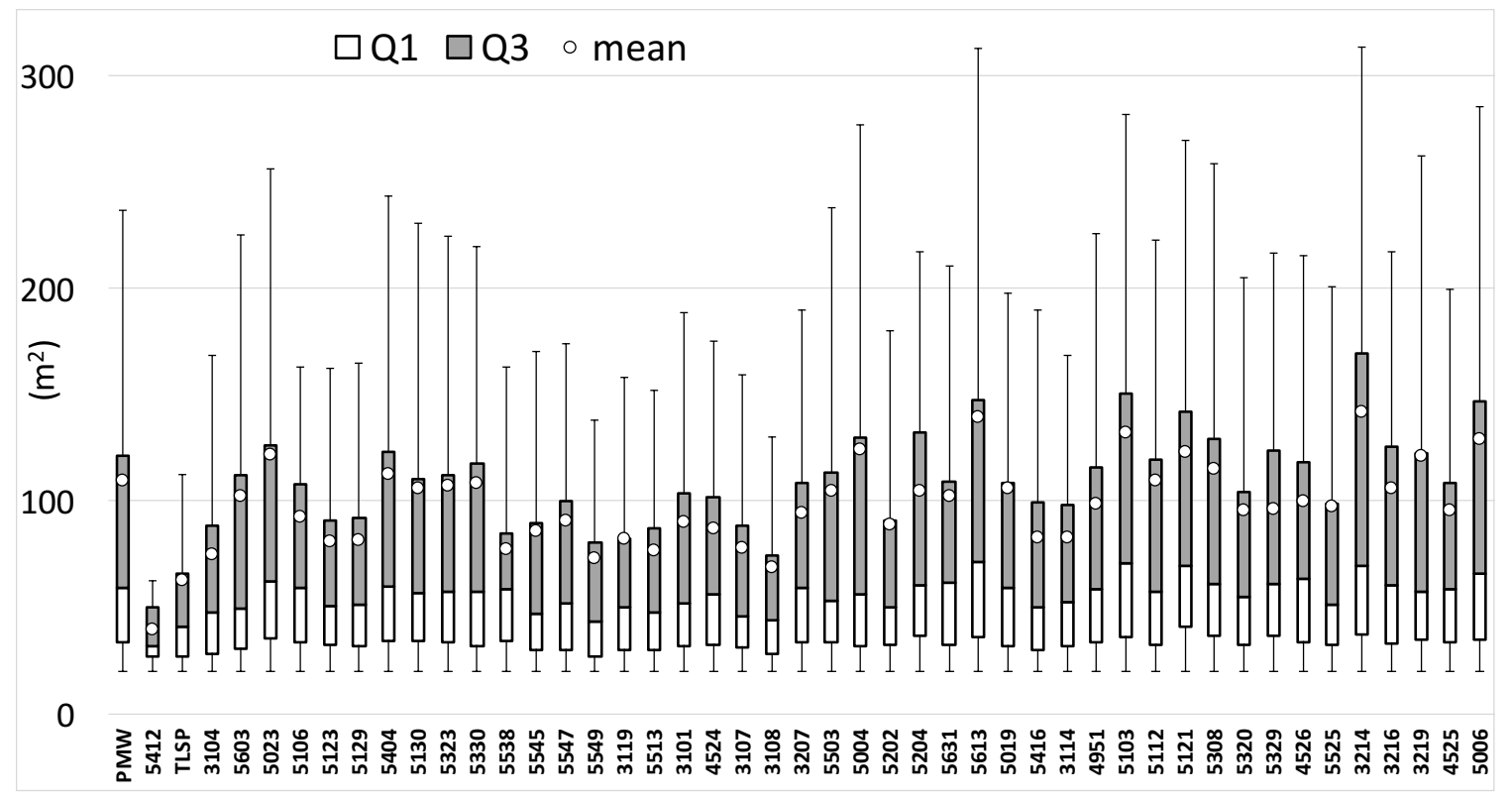

Figure 2.4. Mean gap size distribution measured in pre-storm 2014 imagery across study area units arranged left to right by oldest to most recent harvest. Bars represent $95^{\text {th }}$ percentile. 


\subsubsection{Canopy gap morphology in primary and second growth northern hardwoods}

In 2014, the canopy was more open in $\mathrm{CHC}$ second growth mixed northern hardwoods ( $\mathrm{M}=16.5 \%$ canopy gap $\pm 4.9 \%$, mean \pm standard deviation) than in PMW old growth mixed northern hardwoods $(12.1 \%)(\mathrm{p}<0.05)$. Gaps were more frequent in CHC study units $\left(16.5 \pm 2.8 \mathrm{ha}^{-1}\right)$ than in PMW $\left(10.84 \mathrm{ha}^{-1}\right)(\mathrm{p}<0.05)$. Gap shape index was significantly more complex among second growth forests in CHC $(1.54 \pm 0.07 \mathrm{CI})$ than in PMW $(1.48 \mathrm{CI})(\mathrm{p}<0.05)$. Average gap size was smaller in CHC $\left(98.1 \pm 20.3 \mathrm{~m}^{2}\right)$ than PMW $\left(109.6 \mathrm{~m}^{2}\right)(\mathrm{p}<0.05)$ (Figure 1.4). However, outliers were more extreme in the PMW data set, with a maximum gap size of $7,846 \mathrm{~m}^{2}$ compared to 4,772 in the $\mathrm{CHC}$ study area. Spatial distribution of gap sizes was similar between CHC and PMW; gaps up to $500 \mathrm{~m}^{2}$ were estimated to occur at a rate of one per ha, gaps 500 to $1500 \mathrm{~m}^{2}$ occurred at a rate of one per 50 ha (Figure 1.5). Gaps greater than $2500 \mathrm{~m}^{2}$ occurred at an approximate rate of one per 2500 per ha.

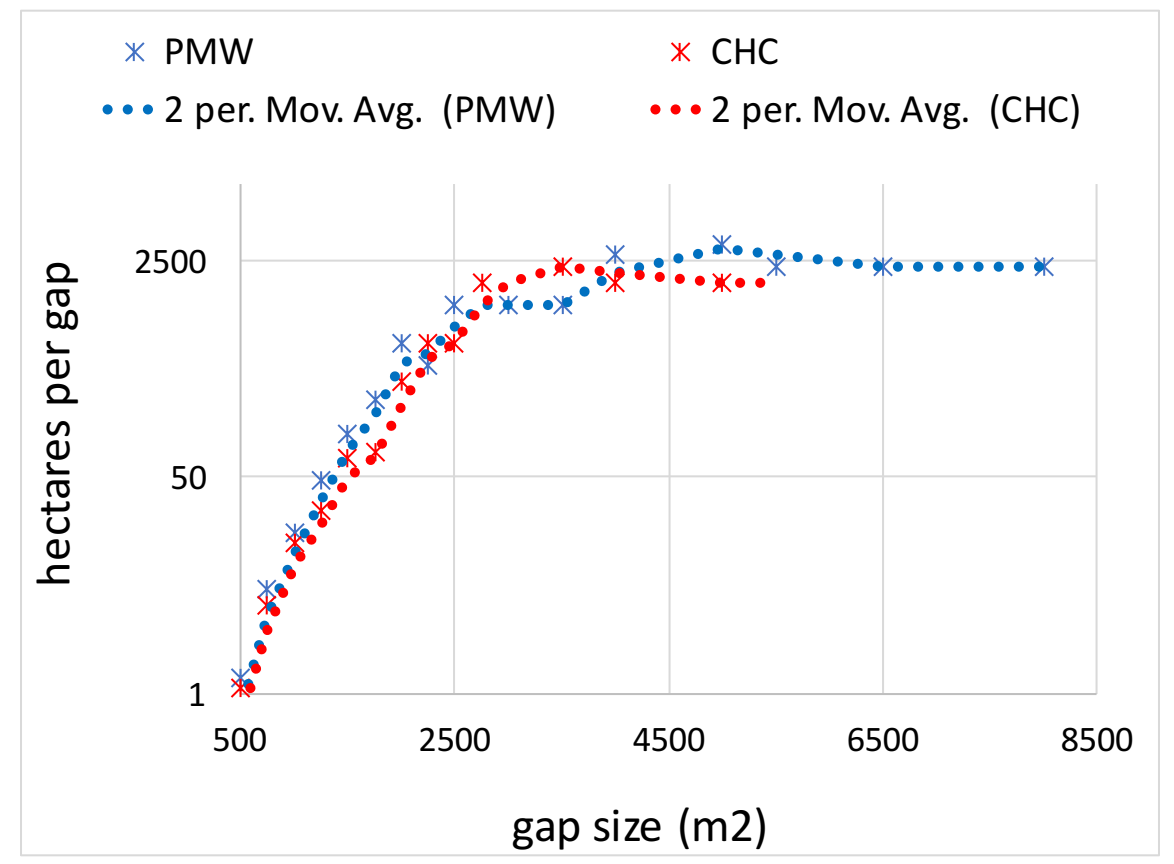

Figure 2.5. Spatial distribution of large canopy gaps in CHC and PMW study area in 2014 N.A.I.P. imagery. Stars represent stand-level data and circles two-period moving average. 


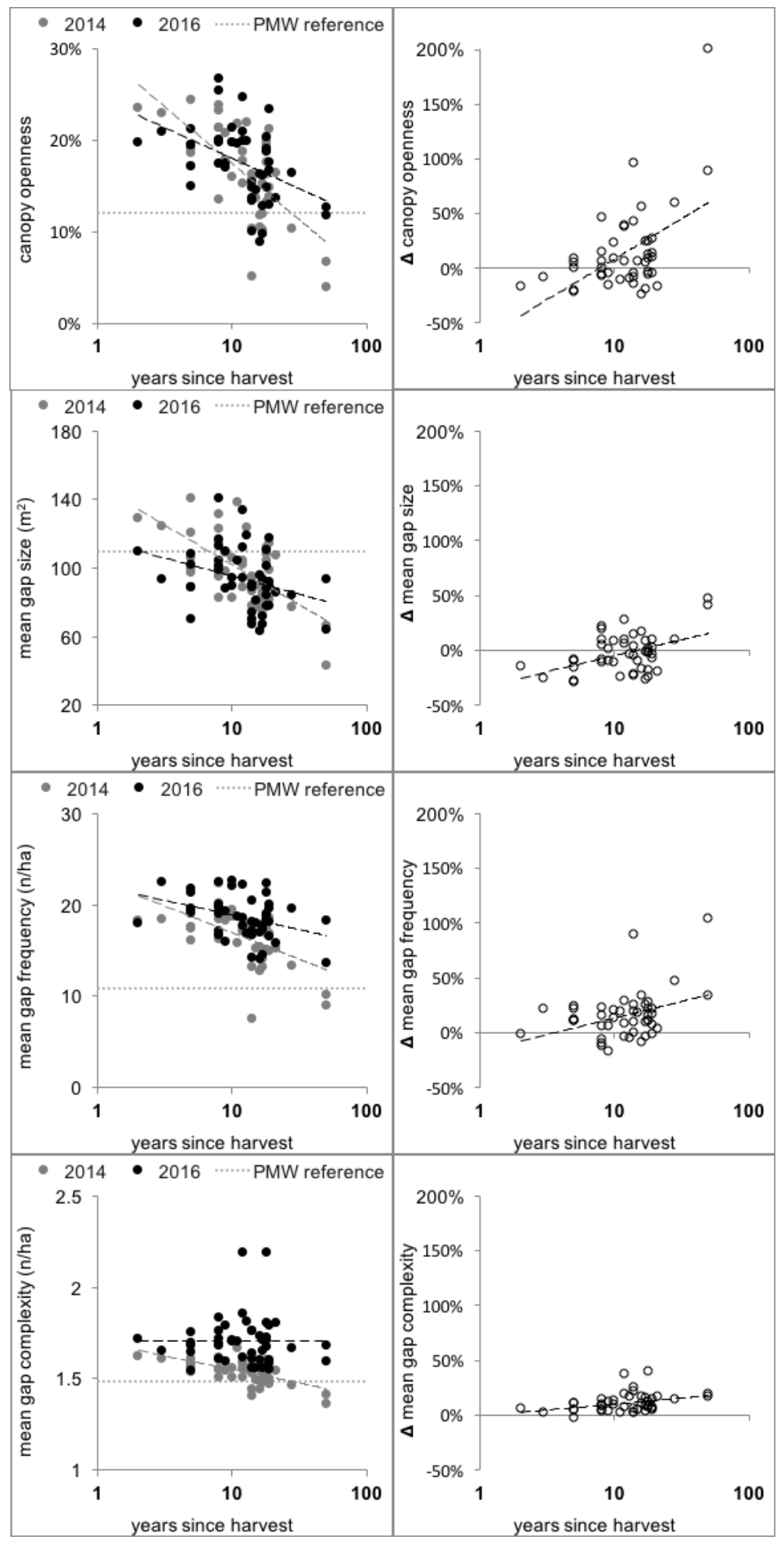

Figure 2.6. Gap morphology vs. years since harvest in 46 second growth northern mixed hardwood stands of central Houghton County, MI and comparison to reference conditions observed in old growth Porcupine Mountain Wilderness. 


\subsubsection{Effects of stands management and storm disturbance on gap morphology}

Gap morphology across the $46 \mathrm{CHC}$ study stands most strongly correlated to time since last harvest in 2014 classified imagery (Figure 1.6). In stands with greater time since harvest, canopies were less open with smaller, less frequent, and more complex gap shapes (Table 1.2). Increasing elevation was associated with smaller gap sizes and less complex shapes. Greater available water storage was associated with higher gap frequency. After the storm, mean canopy openness increased significantly by $1.0 \%$ [paired t-tests, $\mathrm{t}(45)=-2.1, \mathrm{p}=0.04)]$, frequency increased by 2.1 gaps $/ \mathrm{ha}(\mathrm{p}<0.001)$, and shape complexity increased by $0.2(\mathrm{p}<0.001)$; the differences were significant across stands. Mean gap size was not significantly different between 2014 and 2016.

In post-storm OLS analysis, time since last timber harvest continued to be a significant corollary to canopy openness, gap size and frequency, but coefficients were smaller. Increasing slope was more significant as an explanatory variable of less canopy openness, smaller gap size, and less complex shapes. Percent sugar maple in the overstory negatively correlated to gap frequency in 2016. Stands with more time since harvest had larger increases in canopy opening, gap size, frequency and complexity poststorm ( $\Delta$ 2014-2016). Smaller trees were also associated with more complex gap shape. Greater overstory species richness was associated with more canopy opening, and was associated non-significantly with increasing gap frequency. No spatial autocorrelation of any model standard residuals was found. 
Table 2.2 Ordinary least squares regression explanatory models of canopy openness, gap size, and gap frequency in central Houghton County northern hardwoods study area.

$\left(\mathrm{p}<0.05^{*},<0.005^{* *},<0.0005^{* * *},<0.00005^{* * * *}\right) \mathrm{SE}=$ standard error.

\begin{tabular}{|c|c|c|c|c|c|c|c|c|c|}
\hline & \multicolumn{3}{|c|}{ pre-storm (2014) } & \multicolumn{3}{|c|}{ post-storm (2016) } & \multicolumn{3}{|c|}{$\Delta(2014-2016)$} \\
\hline & B & SE & $\mathbf{p}$ & B & SE & $\mathbf{p}$ & B & SE & $\mathbf{p}$ \\
\hline \multicolumn{10}{|c|}{ CANOPY OPENESS (\%) } \\
\hline Model results & \multicolumn{3}{|c|}{$\mathbf{F}(3,42)=19.8, \mathbf{r}^{2}=0.59 * * * *$} & \multicolumn{3}{|c|}{$\mathrm{F}(3,42)=9.0, \mathrm{r}^{2}=0.39 * * *$} & \multicolumn{3}{|c|}{$F(3,42)=18.3, r^{2}=0.57 * *$} \\
\hline Timber harvest (yr) & -0.3 & 0.06 & $* * * *$ & -0.2 & 0.05 & $* *$ & +3.0 & 0.42 & $* * * *$ \\
\hline Elevation (m) & -0.1 & 0.02 & $* *$ & -- & -- & -- & +0.4 & 0.19 & $*$ \\
\hline Species richness (n) & -- & -- & -- & +0.5 & 0.33 & n.s. & +5.6 & 2.71 & $*$ \\
\hline Slope (\%) & -- & -- & -- & -0.4 & 0.13 & $* *$ & -- & -- & -- \\
\hline B.H. (in.) & -0.3 & 0.25 & n.s. & -- & -- & -- & -- & -- & -- \\
\hline \multicolumn{10}{|c|}{ MEAN GAP SIZE $\left(\mathrm{m}^{2}\right)$} \\
\hline Model results & \multicolumn{3}{|c|}{$\mathrm{F}(3,42)=13.7, \mathrm{r}^{2}=0.49 * * * *$} & \multicolumn{3}{|c|}{$F(3,42)=4.9, r^{2}=0.26^{*}$} & \multicolumn{3}{|c|}{$\mathrm{F}(3,42)=9.7, \mathrm{r}^{2}=0.41 * * *$} \\
\hline Timber harvest (yr) & -1.3 & 0.23 & $* * * *$ & -0.6 & 0.25 & $*$ & +1.0 & 0.22 & $* * *$ \\
\hline Elevation (m) & -0.3 & 0.11 & * & -- & -- & -- & 0.2 & 0.11 & n.s. \\
\hline Slope (\%) & -- & -- & -- & -2 & 0.69 & $*$ & -1.4 & 0.57 & $*$ \\
\hline Soil & -1.8 & 1.12 & n.s. & -2.1 & 1.26 & n.s. & - & - & -- \\
\hline \multicolumn{10}{|c|}{ GAP FREQUENCY (n/ha) } \\
\hline Model results & \multicolumn{3}{|c|}{$F(3,42)=24.2, r^{2}=0.63 * * * *$} & \multicolumn{3}{|c|}{$F(4,41)=5.9, r^{2}=0.37 * *$} & \multicolumn{3}{|c|}{$\mathrm{F}(4,41)=6.8, \mathrm{r}^{2}=0.40 * * *$} \\
\hline Timber harvest (yr) & -0.2 & 0.03 & $* * * *$ & -0.1 & 0.03 & $*$ & +1.3 & 0.29 & $* * * *$ \\
\hline Elevation (m) & -- & - & -- & -- & -- & -- & +0.2 & 0.13 & n.s \\
\hline Species richness (n) & -- & -- & -- & +0.4 & 0.2 & n.s & +3.5 & 1.82 & n.s \\
\hline Slope $(\%)$ & -0.2 & 0.08 & n.s. & -0.1 & 0.08 & n.s & +0.9 & 0.73 & n.s \\
\hline Soil AWS (cm) & +0.3 & 0.14 & $*$ & -- & -- & -- & -- & -- & -- \\
\hline A. Saccharrum $(\%)$ & - & - & -- & -0.1 & 0.02 & $*$ & -- & -- & -- \\
\hline \multicolumn{10}{|c|}{ MEAN GAP COMPLEXITY INDEX } \\
\hline Model results & \multicolumn{3}{|c|}{$F(4,41)=14.0, r^{2}=0.56 * * * *$} & \multicolumn{3}{|c|}{$\mathrm{F}(4,41)=6.5, \mathrm{r}^{2}=0.39 * * *$} & \multicolumn{3}{|c|}{$\mathrm{F}(4,41)=7.1, \mathrm{r} 2=0.41 * * *$} \\
\hline Timber harvest (yr) & -0.04 & 0.0007 & $* * * *$ & -- & -- & -- & -0.2 & 0.12 & $*$ \\
\hline Elevation (m) & -0.001 & 0.0003 & $* *$ & -0.002 & 0.0008 & $*$ & -- & -- & -- \\
\hline Species richness (n) & -0.01 & 0.005 & n.s & - & - & -- & -- & -- & -- \\
\hline Slope (\%) & -0.001 & 0.0006 & n.s & -0.007 & 0.001 & $* * *$ & +0.4 & 0.1 & $* * *$ \\
\hline Mean D.B.H. (in.) & - & - & -- & 0.02 & 0.009 & n.s & -1.3 & 0.6 & $*$ \\
\hline Soil AWS (cm) & -- & -- & -- & -0.03 & 0.009 & $* *$ & 2.1 & 0.6 & $* *$ \\
\hline
\end{tabular}




\subsection{Discussion}

This study found that chronology of timber harvest was a key predictor of canopy openness in second growth forests. Greater canopy openness in managed second growth forest compared to primary forest was found to be driven by gap frequency more than gap size. Stands managed by single tree selection had 16-18\% average canopy openness, 17 gaps per hectare and mean gap size of approximately $100 \mathrm{~m}^{2}$. Primary forest in the southern PMW has $12.1 \%$ canopy openness, 11 gaps per hectare and $110 \mathrm{~m}^{2}$ average gap size. This is consistent with previous findings on canopy openness in temperate old growth hardwood forests of North America (Weiskittel and Hix 2003). Canopy gaps in stands with single tree selection harvest within the last 5 years were initially larger, with average gap size of $115 \mathrm{~m}^{2}$. However, rapid contraction of gap size was observed to occur as early as ten years post-harvest. Second growth hardwoods without contemporary single tree selection harvest had the most closed canopy, fewest and smallest gaps.

Across all stands, canopy openness increased by $1 \%$ post-windstorm, a finding that aligns with previous finding on annual rates of small gap creation in mesophytic hardwoods (Runkle 1985). After intermediate thunderstorm disturbance in the two locations with second growth forest not managed for timber harvest, net canopy openness was remarkably similar to canopy openness measured in primary forest. However, the effect was due to more frequent and smaller gaps, not larger gap opening. In post-wind storm imagery, mean gap size decreased in stands with more recent harvest. This indicates rapid closure of gaps post harvest by regeneration and lateral extension of tree crowns into gap spaces was a greater force in determining gap size than wind disturbance in recently harvested stands. Previous studies suggest that soil conditions and topography are at least as important as management history in predicting storm damage (Roberts $e t$ al. 2007). Elevation is this study was found to correlate with decreased canopy openness in 2014, with increasing openness in 2016, and smaller gap size. This is likely attributable to some high elevations being inaccessible to harvest machinery, but more prone to wind damage.

Wind disturbance disproportionality affected second growth forests without timber management. Forest stands with recent single tree selection harvest had little change in 
gap shape, frequency, or complexity after the storm. In contrast, stands harvested longer ago had larger, more frequent gaps after the storm compared to before the storm. Effectively, single tree harvest replaces wind disturbance as the predominate driver of canopy structure and gap formation. Another way of interpreting this observation is that timber harvest and wind disturbance across the second growth forest average each other out, a precursor for landscape level stability (Botkin 1993).

The observations of this study are coarse in nature, derived from a pixelated bird's eye view of the forest. Furthermore, the relatively small study area, particularly for the central Houghton County stands, is a major limitation to this study. Another limitation is the assumption that changes in canopy openness and gap morphology occurring between 2014 and 2016 imagery are primarily attributable to wind disturbance. While harvest is not known to have occurred in the study stands between that period, other disturbances, such as tree mortality from emerald ash borer (Agrilus planipennis), may have contributed to canopy opening. Another limitation is the inevitable landscape-scale differences between the study sites, eighty kilometers apart. This flaw is largely unavoidable, due to the vast clearing of primary forest and loss of ecological reference in the $\mathrm{CHC}$ area. The Porcupine Mountains Wilderness is an enclave on the ancient forests that once sustained the Great Lakes ecosystem and important reference landscape for sugar maple and hemlock forest management (Frelich et al. 2005).

Studying the canopy-gap-dynamics formed by coincident management and natural disturbance interventions may provide insight into how current management techniques could be modified to more closely mimic the natural disturbance events to which native species are adapted (Rogers 1996). Warming air and water temperatures observed in the Great Lakes region between 1979-2006 (Austin and Colman 2007), are predicted to be a persistent trend in coming decades, with the potential to create more intense and/or more frequent storm systems (Bengtsson et al. 2005), and more damage to both infrastructure and forest canopies (CIER 2008). In the case of more frequent or intense storms, canopy in second growth forests may become increasingly open, with potential implications on tree diversity, mortality, and community succession. 


\subsection{Implications for ecosystem-based management}

\subsubsection{Retain biological legacies at harvest}

Sugar maple are well adapted to the small gaps sizes $\left(<1000 \mathrm{~m}^{2}\right)$ produced by single tree selection harvest or severe thunderstorms. Yet, as sugar maple forests age and mature and if greater atmospheric instability from shifting climate patterns produce more frequent and intense storms, wind disturbance will induce new patterns of canopy openness, seedling regeneration, and species succession in northern hardwood forests. Retaining larger trees during single tree selection harvests to facilitate thunderstorm gap creation is an example of an ecological-based management strategy to harness the power of the natural disturbance regime to generate stand complexity and productivity.

\subsubsection{Enhance structural heterogeneity}

Single tree selection management of sugar maple stands allows for retention of contiguous forest cover, encouraging diameter growth on crop trees while removing individuals in poor health or of advanced maturity, as well as propagating shade-tolerant and economically desirable sugar maple. If single tree selection harvest methods were modified to create larger gaps that were fewer in number, recently harvested stands would continue to have greater canopy openness than reference conditions. However, as stands recover from harvest, gap frequency would more closely resemble that of old growth canopy. Based on the findings of this study, to achieve canopy gap structure similar to that found in old growth primary forest of the PMWs, it is recommended that single tree selection be modified to create less frequent gaps. This would allow the addition of forest reserve areas to timber stands, which could be concentrated as a buffer around groves of wildlife trees, cavity snags, or known nests or dens, groves of oak, conifer, yellow birch or other trees adding to species richness, along riparian corridors or edges, or other sensitive features. Reserve areas could also consist of big trees, which contribute to old growth structure, wildlife habitat, fecund regeneration, pest and disease resistance, and environmental quality. McGee et al. (1999) recommend retaining should 
retain at least 16 live trees $/ \mathrm{ha} \geq 50 \mathrm{~cm} \mathrm{D.B.H.} \mathrm{including} 6$ trees $/ \mathrm{ha} \geq 70 \mathrm{~cm} \mathrm{D.B.H.} \mathrm{to}$ emulate old-growth northern hardwoods structure.

\subsubsection{Allow for recovery periods}

Less than 20 gaps per hectare sized up to $150 \mathrm{~m}^{2}$ would create canopy gap conditions similar to primary old growth within the 15-20 year rotation period. Cutting larger gaps should be limited to 1 gap of $500 \mathrm{~m}^{2}$ per ha, 1 gap of $1500 \mathrm{~m}^{2}$ per 50 ha, and 1 gap greater than $2500 \mathrm{~m}^{2}$ per 2500 ha. Logging roads should be counted as gaps under this directive. Furthermore, as remote sensing technologies proliferate and high resolution aerial images become more accessible, aerial imagery and analysis are becoming more and more integrated into forestry, conservation biology, and public land management. At local forest management scales, the use of public domain imagery, such as N.A.I.P., can be integrated into forest management as an efficient way to monitor landscape-level net canopy cover trends resulting from prescribed harvests, natural disturbances, or other local land use changes and monitor disturbance recovery long-term (Davies et al. 2010; Drohan et al. 2012; Hogland et al. 2014).

\subsection{References}

Austin, J. and M. Colman. 2007. Lake Superior Summer Water Temperatures Are Increasing More Rapidly Than Regional Air Temperatures: A Positive Ice-Albedo Feedback. Geophysical Research Letters, 34(6).

Bengtsson, L., K.I. Hodges, And E. Roeckner. 2006. Storm Tracks And Climate Change. Journal of Climate, 19: 3518-3543.

Boose, E.R., D.R. Foster, M. Fluet. 1994. Hurricane impacts to tropical and temperate forest landscapes. Ecological Monographs, 64: 369-400. 
Brewer, R. and P.G. Merritt. 1978. Wind throw and tee replacement in a climax mapleBeech forest. Oikos, 30: 149-152.

Canham, C.D. and O.L. Loucks. 1984. Catastrophic windthrow in the presettlement forests of Wisconsin. Ecology, 65(3): 803-809.

Canham, C.D., M.J. Papaik, E.F. Latty. 2001. Interspecific variation in susceptibility to windthrow as a function of tree size and storm severity for northern temperate species. Canadian Journal of Forest Research, 31(1): 1-10.

Center For Integrative Environmental Research (CIER). 2008. Economic Impacts Of Climate Change On Michigan.

Choi, J., C.G. Lorimer, and J.M. Vanderwerker. 2007. A simulation of the development and restoration of old-growth structural features in northern hardwoods. Forest Ecology and Management, 249(3): 204-220.

Davies, K., S. Petersen, D. Johnson, B. Davis, M. Madsen, D. Zvirzdin, J. Bates. 2010. Estimating juniper cover from national agriculture imagery program (NAIP) imagery and evaluating relationships between potential cover and environmental variables. Rangeland Ecology and Management, 63(6): 630-637.

Day, W.R.1950. The soil conditions which determine wind-throw in forests. Forestry, 23: 90-95.

Degen T., F. Devillez, A.L. Jacquemart. 2005. Gaps promote plant diversity in beech forests in North Vosges, France. Annals Forest Science, 62: 429-440.

Drohan, P.J., M. Brittingham, J. Bishop, K. Yoder. 2012. Early trends in landcover change and forest fragmentation due to shale-gas development in Pennsylvania: a potential outcome for the northcentral Appalachians. Environmental Management, 49: 1061.

Everham, E.M. and N.V. Brokaw. 1996. Forest damage and recovery from catastrophic wind. The Botanical Review, 62: 113-185.

Falkner, E. and D. Morgan. 2002. Aerial Mapping: Methods and Applications. CRC Press.

Fassnacht, K.S., D.R. Bronson, B.J. Palik, A.W. D'Amato, C.G.Lorimer, and K.J. Martin. 2015. Accelerating the development of old-growth characteristics in second-growth northern hardwoods. Gen. Tech. Rep. NRS-144. Newtown Square, PA: U.S.D.A. Forest Service, Northern Research Station. 33 p.

Foster, D.R. 1988. Species and stand response to catastrophic wind in central New 
England, U.S.A. Journal Of Ecology, 76(1): 135-151.

Frelich, L.E., M.W. Cornett, and M.A. White. 2005. Controls and Reference Conditions in Forestry: The Role of Old-Growth and Retrospective Studies. Journal of Forestry, 103(7).

Gardiner, B., G. Stacy, R. Belcher, and C. Wood. 1997. Field and wind tunnel assessments of the implications of respacing and thinning for tree stability. Forestry, 70(3): 233-252.

Hogland, J.S., N.M. Anderson, W. Chung, And L. Wells. 2014. Estimating forest characteristics using NAIP imagery and ArcObjects. ESRI User Conference.

Hubert, E.E. 1918. Fungi as contributory causes of windfall in the Northwest. Journal of Forestry, 16: 696-714.

Keeton, W. S., A. A. Whiteman, G. C. McGee, and C. L. Goodale. 2011. Latesuccessional biomass development in northern hardwood-conifer forests of the northeastern United States. Forest Science 57: 489-505.

King, D.A. 1986. Tree form, height growth, and susceptibility to wind damage in Acer Saccharum. Ecology, 67(4): 980-990.

Lorimer, C.G. and L.E. Frelich. 1994. Natural disturbance regimes in old-growth northern hardwoods. Journal of Forestry, 92: 33-38.

McGee, G.G., Leopold, D.J. and Nyland, R.D. 1999. Structural characteristics of oldgrowth, maturing, and partially cut northern hardwood forests. Ecological Applications, 9: 1316-1329.

Pederson, N., J.M. Varner, B.J. Palik. 2008. Canopy disturbance and tree recruitment over two centuries in a managed longleaf pine landscape. Forest Ecology and Management, 254: 85-95.

Peterson, C.J., and S.T. Pickett. 1991. Treefall and resprouting following catastrophic wind throw in an old-growth hemlock-hardwoods forest. Forest Ecology and Management 42: 205-218.

Putz, F.E., P.D. Coley, K. Lu, A. Montalvo, A. Aiello. 1983. Uprooting and snapping of trees: structural determinants and ecological consequences. Canadian Journal of Forest Research, 13: 1011-1020.

Roberts, S.D., C.A. Harrington, K.R. Buermeyer. 2007. Does variable-density thinning increase wind damage in conifer stands on yhe Olympic Peninsula? Western Journal of Applied Forestry, 22(4): 285-296. 
Rogers, Paul. 1996. Disturbance ecology and forest management: a review of the literature. Gen. Tech. Rep. INT-GTR-336. Ogden, UT: U.S. Department of Agriculture, Forest Service, Intermountain Research Station. 16 p.

Runkle, J.R. 1985. Disturbance regimes in temperate forests. Pages 17-33 in S. T. A. Pickett and P. S. White, editors. The ecology of natural disturbance and patch dynamics. Academic Press, New York, New York, USA.

Schulte, L.A. and D.J. Mladenoff. 2005. Severe wind and fire regimes in northern forests: historical variability at the regional scale. Ecology, 86(2): 431-455.

Singer, M.T., and C.G. Lorimer. 1997. Crown release as a potential old-growth restoration approach in northern hardwoods. Canadian Journal of Forest Research, 27(8): 1222-1232.

Soil Survey Staff, Natural Resources Conservation Service, United States Department of Agriculture. U.S. General Soil Map (STATSGO2). Available online. Accessed $04 / 28 / 2019$.

Sturtevant, B., J. Bissonette, J. Long, D. Roberts. 1997. Coarse woody debris as a function of age, stand structure, and disturbance in boreal Newfoundland. Ecological Applications, 7(2): 702-712.

Trousdell, K.B., W.C. Williams, T.C. Nelson. 1965. Damage to recently thinned loblolly pine stands by Hurricane Donna. Journal of Forestry, 63: 96-100.

USDA, Natural Resources Conservation Service (NRCS). 2016. Geospatial Data Gateway. https://doi.org/10.15482/USDA.ADC/1241880. Accessed 2017-08-20.

USDA-FSA. Aerial Photography Field Office, 125 S State Street Suite 6416, Salt Lake City UT 84138.

Wilson, H. 1976. The effect of the gale of August 1975 on forests In Canterbury, N.Z. Journal of Forestry, 21: 133-140.

Weiskittel, A.R. D.M. Hix. 2003. Canopy gap characteristics of an oak-beech-maple oldgrowth forest in northeastern Ohio. The Ohio Journal of Science, 103(4): 111-115

Xue, J. and B. Su. 2017. Significant remote sensing vegetation indices: A review of developments and applications. Journal of Sensors.

Zhang, Q., K.S. Pregitzer, and D.D. Reed. 1999. Catastrophic disturbance in the presettlement forest of the Upper Peninsula of Michigan. Canadian Journal of Forest Research, 29: 106-114 


\section{Northern hardwood and hemlock seedling bank response to storm disturbance and single tree selection harvest in the southern Keweenaw Peninsula, Michigan}

\subsection{Abstract}

This case study seeks to fill a critical knowledge gap on how natural wind disturbance affects seedling diversity in northern hardwood forests managed by single tree selection methods. Ongoing timber harvests on state managed lands in Michigan's Upper Peninsula employ single tree selection cutting methods to promote more complex uneven-age structure in second growth sugar maple (Acer saccharum) stands. However, low light conditions created by the small dispersed gap pattern created may inhibit regeneration of tree species characterized as moderately or highly intolerant of shade. Overstory tree mortality and understory regeneration were documented by species and size class in 14 multi-tree canopy gaps created by a July 2016 severe summer thunderstorm in second growth forests with and without single tree selection. Storm gaps ranged in size from 125 to $1100 \mathrm{~m}^{2}$ and basswood trees (Tilia americana) were disproportionally downed by wind disturbance. Robust seedling regeneration was released in all hardwood storm gaps, with sugar maple contributing more than $75 \%$ of stem abundance regardless of prior management history. Sugar maple and ironwood (Ostrya virginiana) comprised $80 \%$ of saplings. At only one hardwoods study plot was sugar maple dominance challenged; yellow birch (Betula alleghaniensis) seedlings recruited abundantly in a storm gap where a $38 \mathrm{~cm}$ diameter birch remained windfirm. In an unmanaged upland hemlock forest adjacent to northern hardwoods, hemlock (Tsuga canadensis) seedlings commanded one storm gap but in another, sugar maple and red maple (Acer rubrum) seedlings composed $75 \%$ of seedling regeneration. Results indicate single tree selection of mixed northern hardwood stands does not exacerbate, but rather emulates, dense sugar maple regeneration found on unmanaged second growth sites. 


\subsection{Introduction}

In mixed northern hardwoods, the influence of wind disturbance and subsequent regeneration and recruitment in gaps is a major determinant of forest stand structure and species composition (Jones 1945). This process of canopy opening and closing drives successional development of forests, provides quality habitat for keystone herbivores and gap specialists, and benefits forest health and resilience by increasing structural heterogeneity and facilitating biodiversity (Pickett 1980; Degen et al. 2005; Pederson et al. 2008). In primary forests of Michigan's Upper Peninsula, large canopy openings caused by periodic catastrophic wind disturbance were a primary driver of gap morphology and facilitated the persistence of less shade-tolerant species (Woods, 2000). Large windthrow gaps documented in this region by early land surveys (ca. 1850) ranged widely in size (1-3.4 $\mathrm{km}^{2}$ mean gap size) and had an estimated half- to ten-century rotation period (Canham and Loucks 1984; Zhang et al. 1999; Schulte and Mladenoff 2005). Environmental drivers and origins of plant community diversity have changed since European settlement brought increased pressure on the forest resources of the Upper Peninsula. Human management of forests for timber, recreation, and wildlife now commix with ecological filters and natural processes of plant community development (Stearns 1990). This study seeks to document the interaction of single tree selection timber harvest with gaps from severe thunderstorm disturbance on regeneration in sugar maple (Acer saccharum) dominated mixed hardwoods by comparing responses to the wind event in forests receiving single tree selection to those in adjacent forests that have received no management for over 50 years.

Sugar maple forest swathed across the Great Lakes region is of immense cultural and ecological value. The leaves, buds, bark, and sap are an essential food source for many species including moose, white tailed deer, porcupine, Lepidoptera, and humans, and the wood is a preeminent timber resource throughout its highly productive northern range. As a long-lived, late-successional tree, sugar maple is a shade-bearing species capable of profuse regeneration in the deep shade of its own canopy. Dense seedling banks may persist in low light understories for decades, and grow rapidly upon release when a mature tree falls and the canopy opens (Marks and Gardescu 1998). Sugar maple, 
along with hemlock (Tsuga canadensis), yellow birch (Betula alleghaniensis), and basswood (Tilia Americana), in the western Upper Peninsula (UP), and with the addition of beech (Fagus grandifolia) in the eastern UP are considered to be northern hardwood climax species for this ability to grow in shade and to germinate in the decaying organic matter comprising the old growth forest floor (Graham 1941). Yet, following intensive lumbering of the mid 19th to early 20th century, trees in present-day upper Michigan forests are smaller and more densely arranged than in old growth forests, with major loss of hemlock groves and white pine super canopy trees (White and Mladenoff 1994; Zhang et al. 2000; Leahy and Pregitzer 2003). Along with great simplification of species diversity, age structure also has lost complexity; in place of expansive primeval forests, today's mixed hardwood stands are composed of maturing trees mostly in the 90- to 140year age class.

State management of maple-dominated forest in the western Upper Peninsula uses single tree selection to facilitate demographic transition of timber stands from even to uneven aged structure, while favoring growth and production of high quality maple sawtimber. Stands are entered for harvest at 15-20 year intervals and individual trees or small groups are removed creating small canopy gaps. For example, state guidelines recommend five gaps $65 \mathrm{~m}^{2}$ in area (30 ft. wide) per acre in mature sugar maple stands ('The Compleat Marker' Pierce et al. 1994). However, contemporary shifts in silvicultural thinking have brought increased emphasis to promoting stand complexity and compositional diversity (Fahey et al. 2018). Small gap sizes created by single tree selection harvests may be of insufficient area and sunlight to facilitate recruitment or regeneration of less shade tolerant species such as red oak (Quercus rubra), birch (Betula spp.), or white pine (Pinus strobus), further propagating a homogenous tree community (Della-Bianca and Beck 1985; Schulte et al. 2007; Nowacki and Abrams 2008; Webster et al. 2018). Tree diversity and functional redundancy are essential to northern hardwood forest resilience, ecological function, and health (Körner 2005; Schmidt 2012; Pedro et al. 2015). As a keystone canopy species, major ecological disturbance could occur in the case of sugar maple regeneration failure or cohort senescence due to abiotic and biotic stressors such as prolonged drought (Ellsworth and Reich 1992), acid rain (Duchesne et 
al. 2002), insects, diseases, and interactive effects thereof (Walters 1964), or poor adaptive capacity of this species to likely future climatic conditions (Iverson and Prasad 2001).

The future successional development of maple stands under single tree selection management cannot be considered without taking into account regeneration patterns in naturally occurring wind gaps. As second growth forests mature towards a larger and older tree demographic, wind disturbance is poised to generate larger gaps (Everham and Brokaw 1996; Marks et al. 1999). In dense forests with large trees, a domino pattern of tree fall, where many trees are uprooted when nearby trees topple over, creates large multi-tree canopy gaps (Brewer and Merit 1978). Gaps may continue to grow for several years from late-term health effects and mortality due to of storm root disruptions and crown collisions occurring in storms (Everham et al. 1996). Large assemblages of fallen timber may promote further canopy disturbance as a nidus of fire hazard or fungal growth (Hubert 1918). Furthermore, warming air and water temperatures observed in the Great Lakes region in the period 1979-2006 (Austin and Colman 2007) are predicted to be a persistent trend in coming decades with the potential to create more intense and frequent storm systems (Bengtsson et al. 2006; Del Genio et al. 2007) and to cause more damage to both infrastructure and forest canopies in Michigan (CIER, 2008). Paired with a landscape of maturing northern mixed hardwood forests with larger trees across the western Upper Peninsula, extreme weather events, including intense or new patterns of high winds, could develop greater influence in shaping future forest succession.

This paper presents a case study of the synergistic effects of a severe natural wind storm disturbance and single tree selection on seedling regeneration success, species diversity, and ecological succession in maple dominated forests. The ways in which single tree selection harvest and natural wind disturbance together impact gap architectures and advance species succession in maturing second growth maple stands will unfold across the western Upper Peninsula for many years to come. What is less certain is the potential for inclusivity of other species in regeneration and recruitment within this community, facilitating greater tree species diversity. The objective of this case study is to determine if natural canopy openings from tree fall during a severe 
thunderstorm advances or alleviates maple dominance within gap areas, and assess if a past history of single tree selection harvest affects the seedling response to disturbance.

\subsection{Methods}

\subsubsection{Study area}

The study was located in the Michigan Department of Natural Resources (MIDNR) Baraga Forest Management Unit (FMU) in southern Houghton County ( $46^{\circ} 53^{\prime} \mathrm{N}$, $\left.88^{\circ} 51^{\prime} \mathrm{W}\right)$. The climate of the region is humid continental with mean maximum monthly temperatures of $24{ }^{\circ} \mathrm{C}$ in July, mean minimum monthly temperatures of $-16{ }^{\circ} \mathrm{C}$ in February. Mean annual temperature is $4{ }^{\circ} \mathrm{C}$ and precipitation is $924 \mathrm{~mm}$ (US Climate Data, Twin Lakes, MI 1981-2010). The MI-DNR Baraga Forest Management Unit comprises more than 57,500 ha of publicly owned land, and is managed for diverse objectives including trails and recreation, wildlife and old growth habitat, and timber production. Forests in the study area are predominantly second growth after locally dispersed copper mining activities in the mid to late $19^{\text {th }}$ century followed by intense clear cutting for lumber in the late $19^{\text {th }}$ and early $20^{\text {th }}$ centuries.

A severe summer thunderstorm in the early morning of 21 July 2016 brought 145 $\mathrm{km} / \mathrm{h}(90 \mathrm{mph}$ ) winds across the southern Keweenaw Peninsula creating multiple tree blow downs and damaging camper vehicles at Emily Lake campground. Two years after the storm, tree mortality and regeneration were measured in fourteen multi-tree canopy gaps and in 13 adjacent closed canopy (i.e. non-gap) control plots located across six management units affected by the severe thunderstorm (Fig. 3.1). Canopy gaps were initially identified and measured from $0.6 \mathrm{~m}$ resolution aerial imagery captured 31 July, 2016, then ground truthed to confirm they were multi-tree storm gaps. Closed canopy control plots were established from randomly generated coordinates at least $20 \mathrm{~m}$ from the edge of any image identified storm gaps. Three of the surveyed management units are maple dominated mixed northern hardwoods with a history of regular single tree selection harvests. These forests were last thinned to $60-80 \mathrm{ft}^{2} / \mathrm{acre}\left(14-18.5 \mathrm{~m}^{2} / \mathrm{ha}\right)$ in 1997 or 2011 (Table 3.1). Two management units are maple dominated mixed northern 
hardwoods with no harvests for 50 years or more, one being a state park and the other a long-term research site. One management unit is an upland hemlock-hardwood forest association with no recent history of single tree selection harvests, and is included in comparative analyses to query the potential for sugar maple encroachment into this regionally significant habitat type.

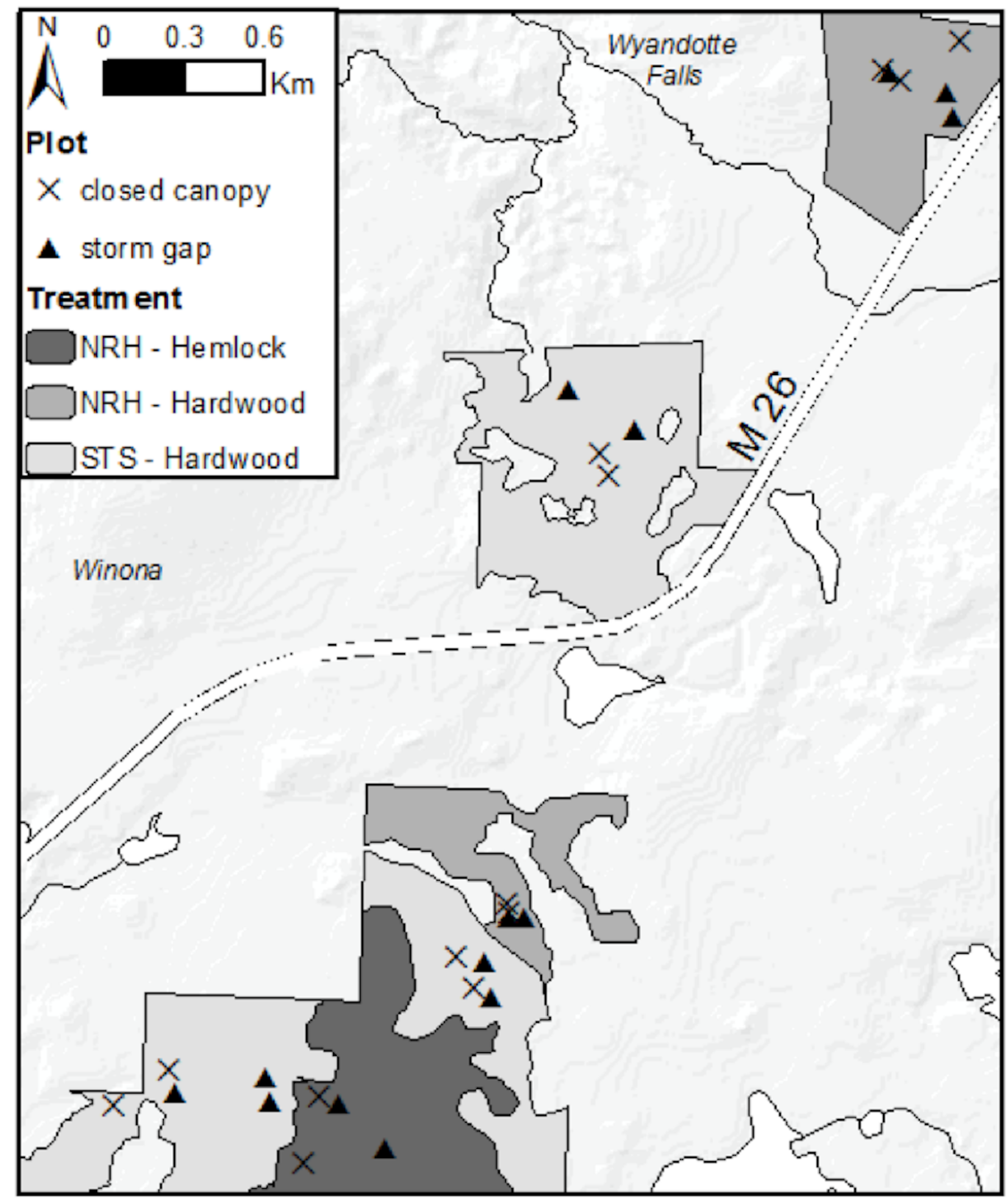

Figure 3.1. Location of closed canopy and storm gap regeneration across six MI-DNR management units in central Houghton County, MI 


\subsubsection{Data collection}

Within each multi-tree storm gap, windthrown and damaged trees $(>12.5 \mathrm{~cm}$ diameter at breast height 'DBH') were inventoried by species and DBH. Orientation of fall was measured with a compass and mechanism of fall was categorized as: tip up, snap, major limb break, or other. Degree of hinge for tipped up trees was measured with a clinometer. Regeneration plots were established at gap center. Control regeneration plots were established at randomly generated coordinates beneath the adjacent closed canopy. At plot centers, standing canopy trees $(>12.5 \mathrm{~cm}$ diameter at breast height, DBH) were surveyed by point sampling using a basal area factor (BAF) 10 wedge prism. Saplings $(>2.5 \mathrm{~cm} \mathrm{DBH})$ were surveyed at plot center within a $7.3 \mathrm{~m}$ radius plot by $\mathrm{DBH}$ and species. Seedlings $(<2.5 \mathrm{~cm} \mathrm{DBH})$ were tallied by species and height class $(30-60 \mathrm{~cm}$, $61-90 \mathrm{~cm},>90 \mathrm{~cm}$ ) within five $2.1 \mathrm{~m}$ radius sample plots located at plot center and at a distance of $7.4 \mathrm{~m}$ in the North, East, West, and South directions. To compare seed bank height extension the length of the 6 most terminal internode stem segments was measured in late summer 2019 for five sugar maple seedlings in the $>90 \mathrm{~cm}$ height class with single dominant stems and growing closest to the plot center.

Table 3.1. Stand characteristics of storm gap and control plot locations

\begin{tabular}{|c|c|c|c|c|c|c|}
\hline $\begin{array}{c}\text { Stand } \\
\text { ID }\end{array}$ & $\begin{array}{c}\text { Harvest } \\
\text { year }\end{array}$ & $\begin{array}{c}\text { Plots with } \\
\text { no gap } \\
\end{array}$ & $\begin{array}{l}\text { Plots with } \\
\text { storm gap }\end{array}$ & $\begin{array}{c}\text { Gap sizes } \\
\left(\mathrm{m}^{2}\right)^{*} \\
\end{array}$ & $\begin{array}{c}\text { BA } \\
\left(\mathrm{ft}^{2} / \mathrm{ac}\right) \\
\end{array}$ & Soil series \\
\hline \multicolumn{7}{|c|}{ Mixed northern hardwoods with single tree harvest ("Harvest hardwood") } \\
\hline 5404 & 1997 & 2 & 3 & $295,462,573$ & $81-110$ & $\begin{array}{l}\text { Munising-Liminga-Alcona and Skanee-Gay } \\
\text { complexes } 0-8 \% \text { slope }\end{array}$ \\
\hline 5413 & 2008 & 2 & 2 & 215,772 & $81-110$ & Graveraet-Misery complex $0-8 \%$ \\
\hline 5525 & 2011 & 2 & 2 & 347,1101 & $70-90$ & Graveraet fine sandy loam $15-60 \%$ \\
\hline \multicolumn{7}{|c|}{ Mixed northern hardwoods with no recent harvest ("No harvest hardwood") } \\
\hline "LTRS" & $\mathrm{N} / \mathrm{A}$ & 2 & 2 & 125,218 & $111-140$ & Liminga fine and Kalkaska sands $0-8 \%$ \\
\hline "TLSP" & $\mathrm{N} / \mathrm{A}$ & 3 & 3 & $283,386,750$ & $111-140$ & Graveraet-Ocqueoc-Kalkaska complex 1-8\% \\
\hline \multicolumn{7}{|c|}{ Upland hemlock-hardwoods with no recent harvest ("Upland hemlock") } \\
\hline 5411 & $\mathrm{~N} / \mathrm{A}$ & 2 & 2 & 274,817 & $140+$ & $\begin{array}{l}\text { Graveraet-Misery and Skanee-Gay } \\
\text { complexes } 0-8 \%\end{array}$ \\
\hline
\end{tabular}

*Wind thrown trees were salvaged from two storm gaps in stand 5404 (295 and $462 \mathrm{~m}^{2}$ gaps) 


\subsubsection{Data analysis}

Relative abundance (\%RA) and stem density of sugar maple, basswood, red maple, yellow birch, hemlock, ironwood, balsam fir, and 'other' tree species were calculated for the following cohorts: windthrown trees $(>12.5 \mathrm{~cm} \mathrm{DBH})$ in storm gaps, standing trees $(>12.5 \mathrm{~cm} \mathrm{DBH})$ out of gaps, saplings $(>2.5 \mathrm{~cm} \mathrm{DBH})$ and seedlings $(<2.5$ $\mathrm{cm} \mathrm{DBH}$ ) in and out of storm gaps. Chi square test of homogeneity was applied to assess if species were more or less likely to be found killed among storm gap windthrow relative to their prevalence out of gap in the surrounding canopy. A two-factor ANOVA was applied to test for significant differences in species composition or stem density of the sapling and seedling cohorts across disturbance ('storm gap' and 'no gap') and management type ('harvest' and 'no harvest'). ANCOVA was applied to assess if gap size correlated with seedling density or diversity. A repeated measures ANOVA with a Greenhouse-Geisser correction was applied to test the effects of time, disturbance, and management on seedling extension growth.

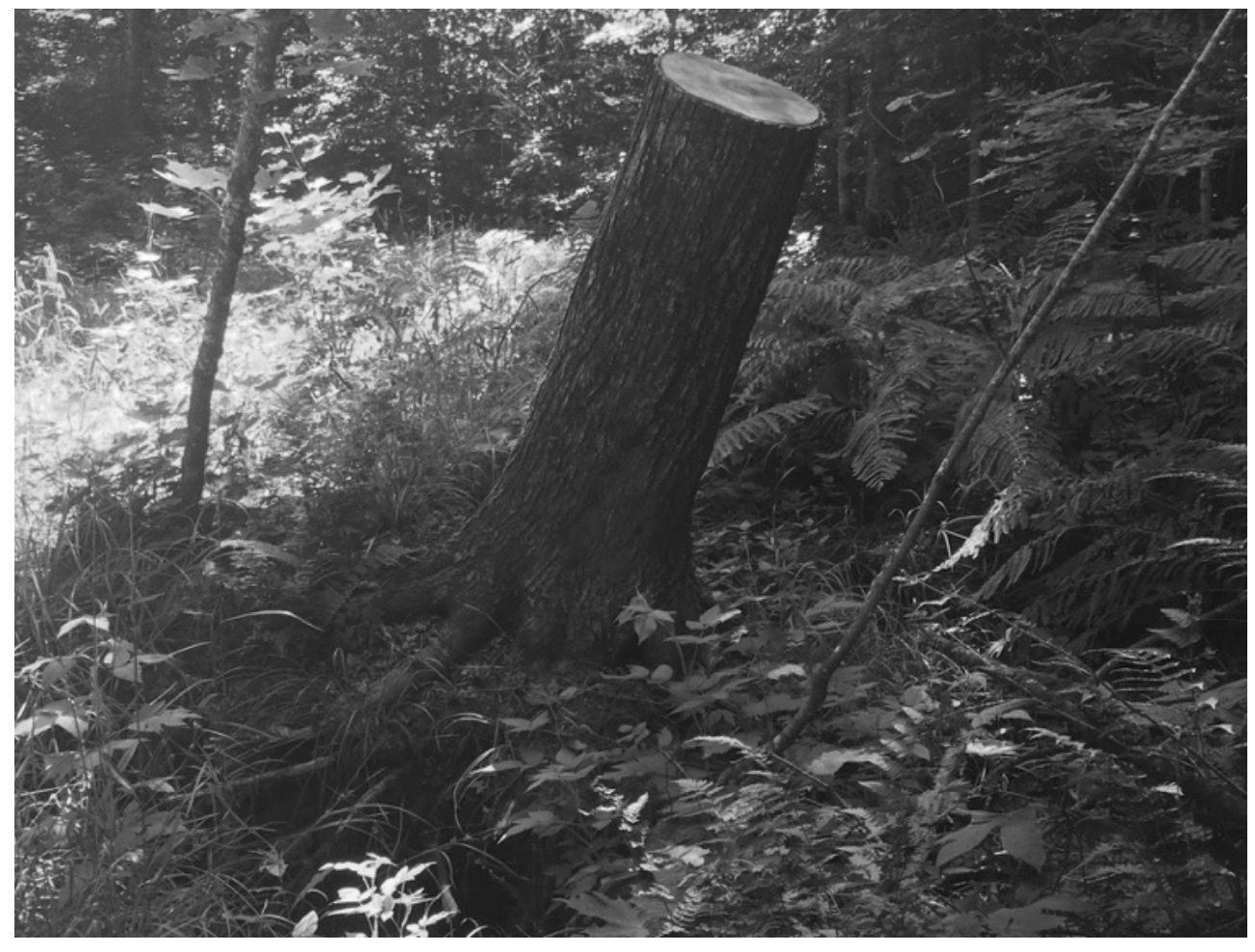

Figure 3.2. Stump of tipped up tree hinged back into vertical position after timber salvage 


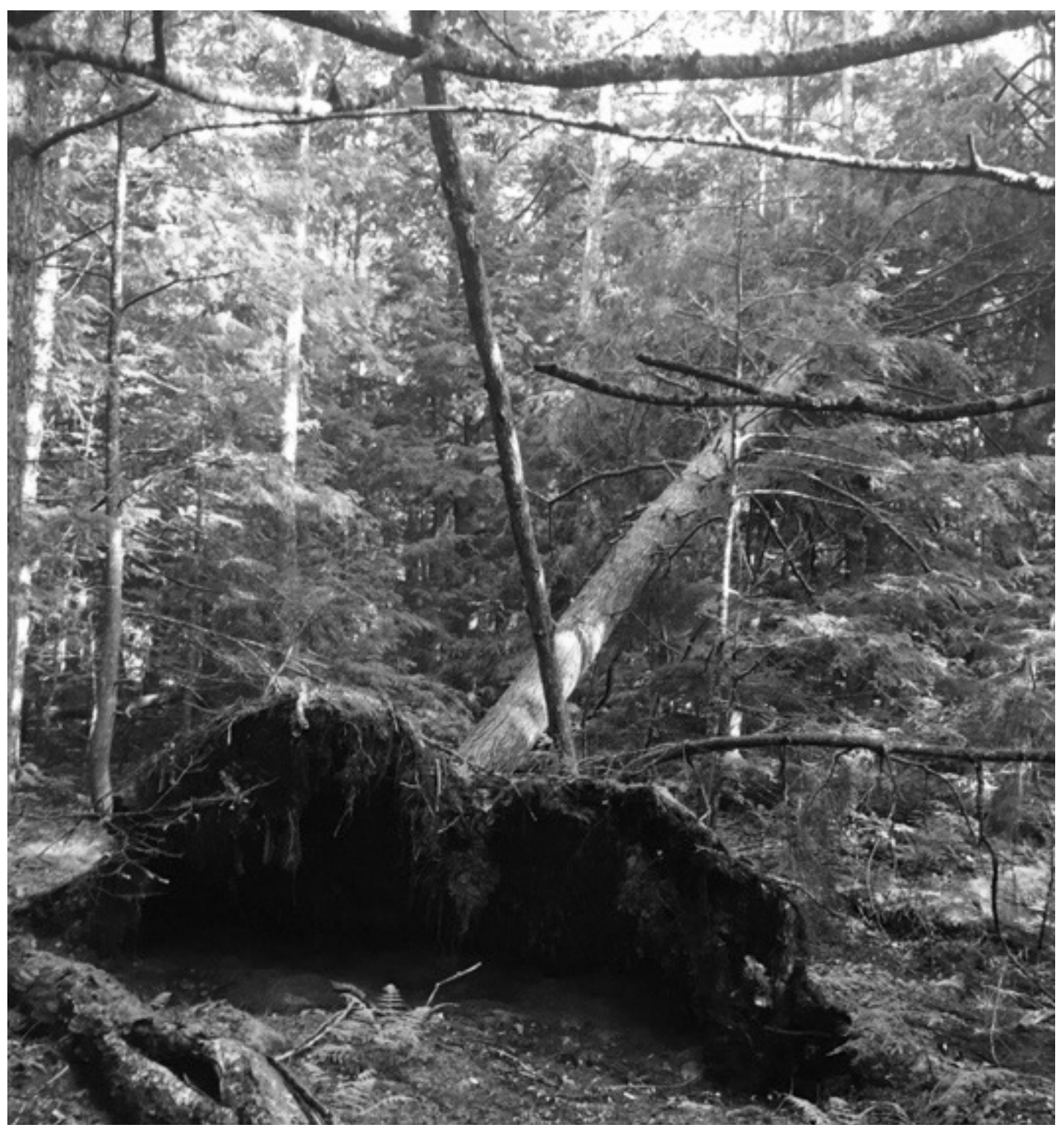

Figure 3.3. Tipped up windthrow tree in hemlock-hardwoods storm gap 


\subsection{Results}

\subsubsection{Observations of storm damage}

A total of 283 windthrown and damaged trees representing 10 species were observed across 14 surveyed storm gaps in hardwood and hemlock hardwood stands affected by the severe summer thunderstorm. Gap sizes ranged from 125 to $1100 \mathrm{~m}^{2}(\mathrm{M}=$ $473 \pm 277$, mean \pm standard deviation). Number of damaged trees per gap ranged from 5 to 43 individuals. Wind fall occurred in a linear domino pattern in all surveyed gaps. Predominant orientation of fall was easterly with an interquartile range of 78-130 degrees. Tip up was the most common mechanism of fall accounting for $81 \%$ of wind damaged trees (Fig. 3.3). Snapped trunks occurred in another 13\% of trees, loss of both major limbs in $4 \%$ of trees, and bending in $2 \%$ of trees. Snapped trees were more likely to be a direct cause of wind, and was the observed damage in $58 \%$ of trees not struck by other trees ( $\mathrm{n}=$ Of tip ups 172 were hinged at an angle of 30 degrees or less with almost total separation of the root ball from the soil. Partial tip ups were less common, observed in 21 trees hinged at greater than a 30 degree angle with partially preserved root-soil connections and frequently with epicormic sprouting. In two storm gaps where windthrown timber was salvaged by the MI-DNR post storm, 43 tree stumps from tipped up trees had hinged back into vertical position, found on mounded uprooted root balls (Fig. 3.2).

\subsubsection{Canopy and windthrow species composition}

In stands with recent single tree harvest the overstory was dominated by sugar maple $(55 \pm 34 \%)$, and co-associated with white ash (Fraxinus americana) $(12 \pm 20 \%)$, red maple $(12 \pm 22 \%)$, and basswood $(11 \pm 14 \%)$ (Fig. 3.4A). Windthrown trees were codominated by sugar maple $(47 \pm 22 \%)$ and basswood $(35 \pm 22 \%)$ (Fig. 3.4B). In stands with no harvest sugar maple was the most common overstory tree species $(84 \pm 19 \%)$ and heavily dominated the storm gap windthrow $(70 \pm 22 \%)$. Basswood was disproportionately observed among windthrow compared to the surrounding canopy, regardless of management history (Table 3.2). In stands with no harvest, sugar maple was 
more likely to be found in the surrounding canopy than killed by the wind. Red maple was homogenously distributed among windthrow and canopy in both management types. The diameter of windthrown trees was similar between single tree harvest $(28.4-44.9 \mathrm{~cm}$ DBH inter-quartile range) and no harvest $(26.2-45 \mathrm{~cm})$ stands.
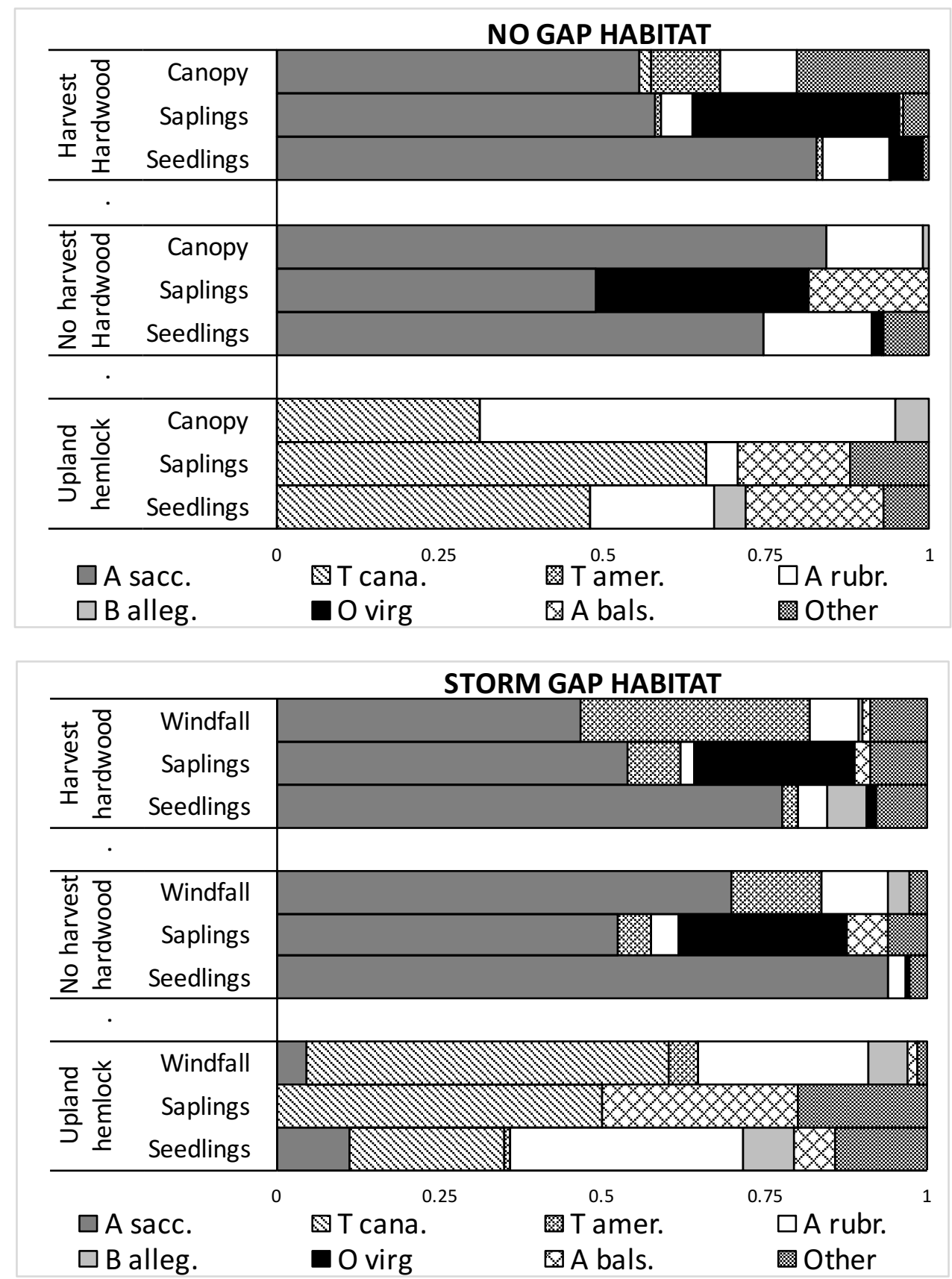

Figure 3.4. Relative abundance of windthrow, sapling, and seedling species in closed canopy without storm gap (A) and in storm gaps (B) across management types 


\subsubsection{Northern hardwood sapling species composition}

The sapling communities were dominated by sugar maple $(54 \pm 27 \%)$ or ironwood (Ostrya virgiana) $(29 \pm 24 \%)$ in all hardwood microsites regardless of wind disturbance or harvest. Sapling density was greatest beneath closed canopy of stands with recent single tree harvest $\left(1226 \pm 1030\right.$ stems $\left.^{-1} \mathrm{ha}^{-1}\right)$, and lowest in storm gaps of stands with no harvest $\left(252 \pm 88\right.$ stems $\left.^{-1} \mathrm{ha}^{-1}\right)$. Differences across management histories were not significant. Balsam fir was present in the sub canopy at $100 \%$ of unmanaged study sites, with mean relative abundance of $19 \%( \pm 4 \%)$, and rarely found in managed sites $(3$ $\pm 6 \%)$.

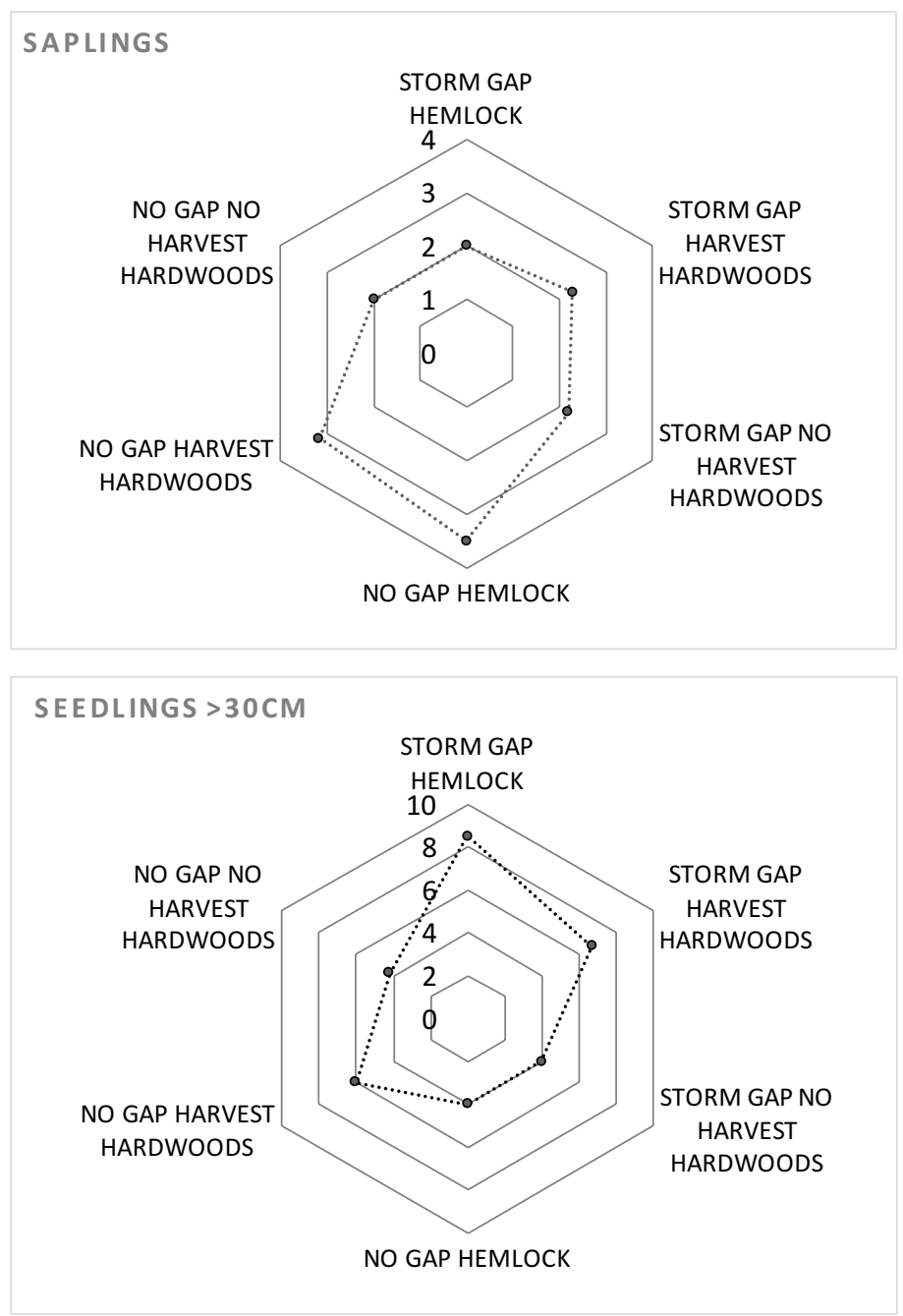

Figure 3.5 Species richness in sapling (A) and seedling (B) cohorts across treatments 


\subsubsection{Seedling diversity, density, and growth}

A total of 5,482 seedlings were categorized by species and height class (30-60 $\mathrm{cm}, 61-90 \mathrm{~cm},>90 \mathrm{~cm}$ ) in the hardwood stands. The seedling layer was found to be strongly dominated by sugar maple $(83 \pm 14 \%$ relative abundance $)$ predominantly in the $30-60 \mathrm{~cm}$ height classes, with no significant effect of storm disturbance or harvest.

Relative abundance of other species was locally variable; red maple comprised $6 \%$ of all counted seedlings, yellow birch, white ash, red oak, and ironwood each comprised 2\%. One storm gap located on a northwest facing slope in a stand harvested by single tree selection in 2011 (FSC 5525, $347 \mathrm{~m}^{2}$ ) was most diverse. Here, yellow birch seedlings were abundantly distributed throughout the gap, comprising $40 \%$ relative abundance, alongside $42 \%$ sugar maple. Two mature trees, basswood and yellow birch, remained standing in the gap.

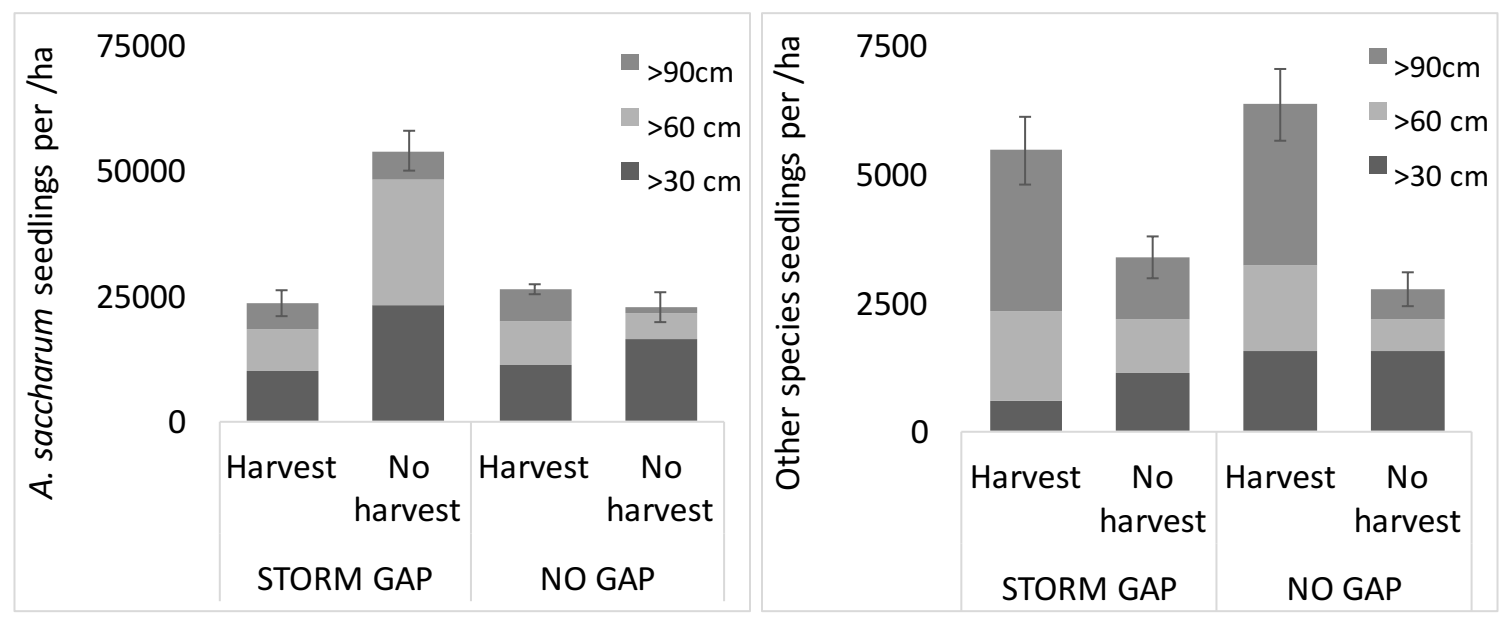

Figure 3.5. Density of Acer saccharum seedlings by height class (A) and density of other species seedlings by height class (B). Error bars represent standard error of total density.

Two-way ANOVA indicated a significant negative effect of harvest $(\mathrm{F}(1,110)=$ $14.4, \mathrm{p}<0.01)$ and a positive effect of storm gap opening $(\mathrm{F}(1,110)=15.8, \mathrm{p}<0.01)$ on sugar maple seedling density. Additionally, there was a significant interaction of storm and harvest $(\mathrm{F}(1,111)=24.4, \mathrm{p}<0.01)$. In no harvest stands, sugar maple seedlings were twice as dense in storm gap plots compared to plots out of gaps (Fig. 3.5A). There was a positive effect of single tree selection harvest on seedling density of other species $(F(1,111)=9.3, p<0.01)$, and no significant effect of storm disturbance $(p=0.9)$ (Fig. 
3.5B). There was no effect of gap size on seedling density of sugar maple or other species (One-way ANCOVA, $\mathrm{p}=0.5$ ) after accounting for harvest. Length of stem internodes were significantly greater in storm gaps $(6 \pm 1 \mathrm{~cm})$ than closed canopy plots $(2 \pm 1 \mathrm{~cm})$ [Repeated measures ANOVA $(\mathrm{F}(1,37)=10.6, \mathrm{p}<0.01)]$, with no observed effect of gap size or harvest (Fig. 3.6).

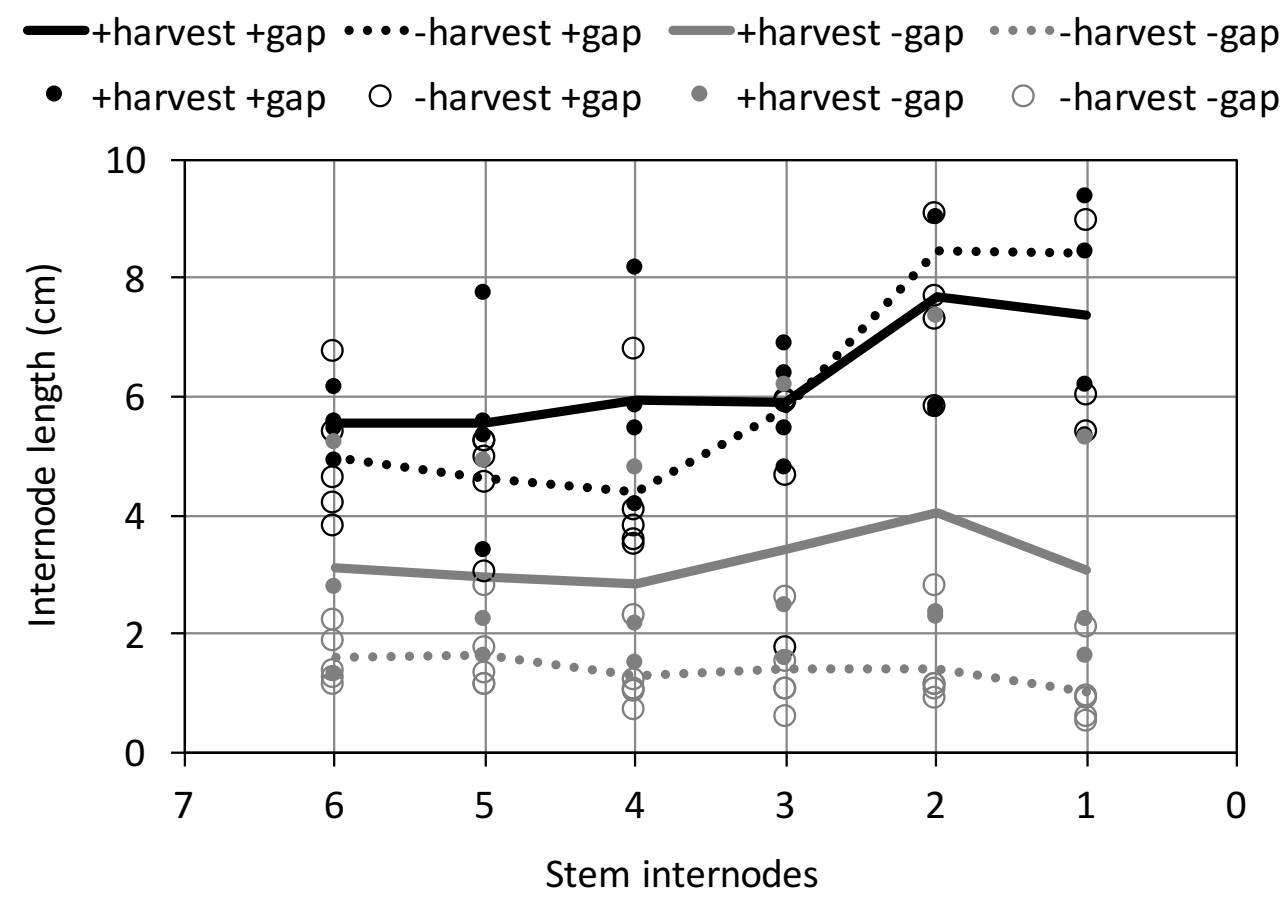

Figure 3.6. Stem extension growth of Acer saccharum seedlings. Solid and dashed lines illustrate mean internode length across study plots. Circles are means for individual plots.

\subsubsection{Hemlock-hardwood species composition}

In the hemlock-hardwoods study plots without wind disturbance, the tree community was predominantly red maple $(63 \pm 7 \%)$ co-associated with hemlock $(31 \pm$ $4 \%)$ and yellow birch in the overstory, and in the understory hemlock with minor components of balsam fir, white spruce (Picea glauca), red maple and red oak. The seedling bank beneath closed canopy was sparse, with an average density of 2520 stems $^{-1}$ $h^{-1}( \pm 839)$, mostly consisting of hemlock, balsam fir, and red maple (Fig. 4B). 
Windthrow in hemlock gaps consisted of larger trees (30.0 - $45.0 \mathrm{~cm}$ DBH IQR) than hardwoods. Patterns of tree mortality and regeneration were distinct between the two surveyed storm gaps. In the larger gap $\left(817 \mathrm{~m}^{2}\right)$ mature hemlock trees comprised $89 \%$ of documented windthrow, $100 \%$ of saplings, and $46 \%$ of seedlings. The smaller storm gap $\left(274 \mathrm{~m}^{2}\right)$ was more diverse; windthrow was a mix of red maple (47\%) and hemlock (22\%). Surviving saplings were largely balsam fir $(60 \%)$ accompanied by equal parts red oak and black cherry (Prunus serotina); seedlings were predominantly red maple (54\%) with notable infiltration by sugar maple (22\%) and a few yellow birch (7\%). Sapling density was sparser in storm gaps $\left(267 \pm 30\right.$ stems $\left.^{-1} \mathrm{ha}^{-1}\right)$ than beneath closed canopy (504 \pm 89 ) possibly due to heavy mortality from tree fall. Seedling density in the hemlockhardwood storm gaps $\left(10230 \pm 7129\right.$ stems $\left.^{-1} \mathrm{ha}^{-1}\right)$ was sparser than in hardwood storm gaps $\left(36093 \pm 12487\right.$ stems $\left.^{-1} \mathrm{ha}^{-1}\right)$.

Compared to the composition of over story trees sampled in areas without wind disturbance, observed counts of hemlock were higher and red maple were lower than expected among wind fall mortality $\left(X^{2}(4, N=197)=31.6, p=<0.00\right)$.

Table 3.2. Comparison of species abundance in windthrow, weighted by canopy distribution in $\mathrm{chi}^{2}$ test of homogeneity. Superscript $\mathrm{a}$ and $\mathrm{b}$ denote significant difference.

\begin{tabular}{lccccc} 
& \multicolumn{2}{c}{ Canopy } & \multicolumn{2}{c}{ Windthrow } & chi square \\
Stand characteristic & $\mathrm{n}$ & $\%$ & $\mathrm{n}$ & $\%$ & result \\
\hline \hline Harvest hardwoods & & & & & \\
Acer saccharum & 56 & $54 \%$ & 47 & $46 \%$ & $\mathrm{X}^{2}=31.0$ \\
Fraxinus americana & $\mathbf{1 3}^{\mathrm{a}}$ & $\mathbf{1 0 0} \%$ & $0^{\mathrm{b}}$ & $0 \%$ & $\mathrm{df}=4$ \\
Acer rubrum & 12 & $61 \%$ & 8 & $39 \%$ & $\mathrm{~N}=187$ \\
Tilia americana & $11^{\mathrm{a}}$ & $23 \%$ & $\mathbf{3 5}^{\mathrm{b}}$ & $\mathbf{7 7} \%$ & $p=0.00$ \\
Quercus rubra & 7 & $85 \%$ & 1 & $15 \%$ & \\
No harvest hardwoods & & & & & \\
Acer saccharum & $\mathbf{8 9}^{\mathrm{a}}$ & $\mathbf{5 6} \%$ & $70^{\mathrm{b}}$ & $44 \%$ & $\mathrm{X}^{2}=22.1$ \\
Acer rubrum & 7 & $42 \%$ & 10 & $58 \%$ & $\mathrm{df}=2$ \\
Tilia americana & $0^{\mathrm{a}}$ & $0 \%$ & $\mathbf{1 4}^{\mathbf{b}}$ & $\mathbf{1 0 0} \%$ & $\mathrm{~N}=191$ \\
Upland hemlock & & & & & $p=0.00$ \\
Tsuga canadensis & $31^{\mathrm{a}}$ & $36 \%$ & $\mathbf{5 5}^{\mathrm{b}}$ & $\mathbf{6 4} \%$ & \\
Acer rubrum & $\mathbf{6 3}^{\mathrm{a}}$ & $\mathbf{7 1} \%$ & $26^{\mathrm{b}}$ & $29 \%$ & $\mathrm{X}^{2}=31.6$ \\
Betula alleghaniensis & 5 & $48 \%$ & 6 & $53 \%$ & $\mathrm{df}=4$ \\
Tilia americana & $0^{\mathrm{a}}$ & $0 \%$ & $\mathbf{5}^{\mathrm{b}}$ & $\mathbf{1 0 0} \%$ & $\mathrm{~N}=197$ \\
Acer saccharum & $0^{\mathrm{a}}$ & $0 \%$ & $\mathbf{5}^{\mathbf{b}}$ & $\mathbf{1 0 0} \%$ & $p=0.00$ \\
\hline
\end{tabular}




\subsection{Discussion}

\subsubsection{Acer saccharum regeneration in storm gaps.}

Following canopy disturbance by severe thunderstorms in the southern Keweenaw Peninsula, the seedling layer in mixed northern hardwoods was robust and dominated by sugar maple (Acer saccharum) both in and out of multi-tree storm gaps sized 125 to $1100 \mathrm{~m}^{2}$. In stands not managed by selection harvest the storm gap seedling bank burgeoned to an average density of more than 50,000 stems per hectare of at least

$30 \mathrm{~cm}$ height $\left(5\right.$ per $\mathrm{m}^{2}$ ). A strongly developed sapling layer in stands managed by single tree selection likely inhibited sugar maple seedlings from such extensive proliferation in storm disturbed canopy openings. Whereas seedling regeneration in gaps was robust, seedlings lacked species diversity. Mean relative seedling abundance of sugar maple exceeded $75 \%$ in stands with harvest, and $85 \%$ in stands without. Harvested stands had modestly greater seedling diversity, with more than 5,000 stems per hectare of other species compared to 2,500 stems in unmanaged stands.

Sugar maple seedlings were moderately less dominant among the tallest height class, comprising 70\% relative abundance of seedlings greater than $90 \mathrm{~cm}$, compared to nearly $85 \%$ overall in the hardwood study areas. Ironwood, an understory component of northern hardwoods, was more abundant in the tallest height class, particularly out of storm gaps. In the one observed storm gap where yellow birch seedlings challenged Acer dominance, yellow birch was twice as abundant in the greater than $90 \mathrm{~cm}$ height class indicating good chance of species succession to form a grove of yellow birch at this site. A standing yellow birch in the gap was likely the primary source of seed.

Overstory presence did not translate to regenerative success for other species, such as red oak. In one storm gap two large oaks remained windfirm, but oak seedlings were less than $1 \%$ of observed regeneration. In two non storm gap plots, oaks comprised up to 15 and $20 \%$ of the overstory, but only 2 and $6 \%$ of seedling regeneration. Poor regeneration of oak is a widespread issue in central and northern hardwood forests, and is especially pronounced in less xeric, more mesic sites with dense canopy (Loftis and McGee 1992). 
Across management type, storm disturbance elicited greater height growth among sugar maple seedlings as evidenced by accelerated extension of the two most terminal shoot segments of nearly $16 \mathrm{~cm}$ in storm gaps compared to 1 to $4 \mathrm{~cm}$ out of gaps. In 20to 25-year old sugar maple in Vermont, Gregory (1980) found two to six internodes in a year's growth for apical shoots with total annual shoot extension up to $50 \mathrm{~cm}$ in gap habitat. This study observed six internodes equaling $37 \mathrm{~cm}$ in total extension length gaps measured three years post storm event. Personal observations of sugar maples seedlings in high sunlight during the initial growth period following budburst in the spring of 2020 found annual growth to consist of three internodes, with occasional occurrences of four internodes. Sugar maple's determinate buds are pre-formed the previous year and conversion of shade leaves to fully sun adapted leaves in a location suddenly exposed to high sunlight levels can take 2 years; and cause a positive response to light to become even greater over time (Jones and Thomas 2007). In 15 to $60 \mathrm{~cm}$ tall sugar maple seedlings aged 15 to 20 years old, Marks and Gardescu (1998) found no height response within the first year of opening an experimental canopy gap and peak stem extension occurred in the fifth year (a median of $26 \mathrm{~cm}$ ).

\subsubsection{Windthrow disturbance and tree species diversity.}

The observed sizes of canopy openings created by the severe thunderstorm disturbance, measuring between $125-1100 \mathrm{~m}^{2}$, did not foster increased diversity in the seedling layer compared to that existing under closed canopy. Larger gaps may be necessary for the recruitment of less shade tolerant species, especially as lateral growth of canopy trees into the gap limit light infiltration over time. The regeneration of early successional tree species is a critical component to preserving forest diversity (Franklin 1988). Historically, catastrophic windthrow and wildfire in northern Michigan created canopy openings up to a thousand fold larger than the storm gaps surveyed here (Zhang et al. 1999). The open light of such vast canopy disturbances provided suitable environments for establishment of white pine, northern red oak, birches, and other less shade tolerant species. Expansive primal forests of these species were largely extirpated 
from the western Upper Peninsula as a momentous ecological legacy of Michigan's lumber era which peaked from the late $19^{\text {th }}$ to early $20^{\text {th }}$ centuries.

Sugar maple was likely a major component of the understory and mid-story in upper Michigan forests beneath the mixed canopy and white pine super canopy. Storm events strong enough to topple white pine may have created gaps larger than the ones observed here, with potentially more diverse regeneration. The mechanisms by which sugar maple outcompeted other species in the stand regeneration phase following historic clear cutting is not certain, but likely involved a combination of seedling bank response, advance regeneration of this tolerant species, and stem sprouting. Once established and without substantial disturbance, dense sugar maple canopies are self-propagating. Harvest methods such as single tree selection maintain this alternative stable state by creating the small gap sizes in which sugar maple thrive (Canham 1989). Dense canopy microclimates may further alter the landscape by cooling and humidifying the environment in a process coined 'mesophication' (Nowacki and Abrams 2008). Mesophication of Lake States forests may alter the response of regional ecosystems to climate disturbances. In upper Michigan, alternative silviculture treatments such as patch cuts, irregular shelterwood, and other even- or multi-aged methods are receiving increased attention for their application in diversifying maple dominated hardwood stands.

The limited number of surveyed storm gaps $(n=14)$ and control points $(n=13)$ combined with diverse soil types, management histories, and other landscape variables limit application of this study's results beyond a local case study. Sugar maple is a long lived species with a potential lifespan of 300 to 400 years on productive sites.

Contemporary management of forest resources across the Upper Peninsula will influence the future ecological legacy of our landscape. There is no blueprint for the natural successional trajectory of even-aged second growth Acer dominated stands; they likely represent an alternative stable state produced from novel human and environmental interactions over the space of the last two centuries. . Old growth forests often persist in stable states, without major disturbance, where nutrient input and outputs are relatively equal, net growth equals mortality or decline (Keeton et al. 2011). An alternative stable 
state of sugar maple may be unlikely to undergo substantial transition to other community type. Results from this study indicate intermediate storm disturbance further propagates recruitment of sugar maple regeneration and there is no additional effect of single tree selection on this phenomenon.

\subsection{Implications for ecosystem-based management}

\subsubsection{Retain biological legacies at harvest}

In this study the most diverse seedling regeneration post storm disturbance occurred in hemlock-hardwood stands. Hemlock stands have significantly contracted in total land cover over the past century (Zhang et al. 2000). Management to conserve this habitat type is important to ensure the ecological integrity of the Tsuga forest community and preserve between-stand tree diversity across the landscape. Retention of Tsuga within hardwood stands is equally important to enhance within-stand diversity. Seed trees of all minor associates in sugar maple communities should be retained to increase seedling regeneration diversity.

\subsubsection{Enhance structural heterogeneity}

In managing healthy forests of sugar maple canopy with robust seedling regeneration there are trade-offs to implementing even-aged silvicultural systems for the goal of increasing tree diversity. Single tree selection harvests and the sugar maple associations they maintain have numerous beneficial outcomes such as providing contiguous forest cover for culturally and ecologically important shade adapted plant and animal species, transitioning even-aged stand structure to uneven-aged, and supporting the economic vitality of regionally significant industries such as maple syrup and hardwood lumber. Modifications to single tree selection harvest, such as retaining larger individuals or groups of legacy trees to allow the natural process of maturation, decline, and larger gap creation, could facilitate future species diversity. Retaining yellow birch and basswood would facilitate natural wind gap formation and wind gap regeneration in 
managed hardwood stands. The economic loss of retaining a greater number of large diameter trees may be offset by the ecological benefits of big trees such as adding structural complexity, stand fecundity and seed dispersal, and creating wildlife habitat, in particular for cavity and den nesting species.

\subsubsection{Allow for recovery periods}

Initial regeneration patterns post disturbance are an imperfect indicator of future successional patterns as gap phases are temporary. Successional ecological processes will continue to operate in and around the canopy opening for years after the initial disturbance has subsided. Storm gaps may be nodes for secondary tree fall events due to greater turbulence and exposure, and down dead wood hazards such as wildfire or pathogenesis. Tree uprooting is a form of floral-pedoturbation and leads to the development of cradle knoll topography that provides heterogeneous substrates and structural complexity to support more diverse regeneration patterns (Schaetzl et al. 1989). Exposed sediments in the pit and mounds of tipped root balls, and later in time the development of nurse logs, may allow more diverse regeneration in gaps at a longer time scale than the two years post disturbance studied here.

\subsection{References}

Austin, J. And M. Colman. 2007. Lake Superior summer water temperatures are increasing more rapidly than regional air temperatures: A positive ice-albedo feedback. Geophys. Res. Lett., 34(6).

Bengtsson, L., K.I. Hodges, And E. Roeckner. 2006. Storm tracks and climate change. J. Clim., 19: 3518-3543.

BREWER, R. AND P.G. MERRITT. 1978. Wind throw and tree replacement in a climax maple-beech forest. Oikos, 30: 149-152. 
CANHAM, C.D. 1989. Different responses to gaps among shade-tolerant tree species. Ecology, 70(3): 548-550.

------ AND O.L. LOUCKS. 1984. Catastrophic windthrow in the presettlement forests of Wisconsin. Ecology, 65(3): 803-809.

CENTER For InTEGRATIVE ENVIRONMENTAL RESEARCH (CIER). 2008. Economic impacts of climate change on Michigan. University of Maryland.

Degen, T., F. Devillez, And A.L. JACQUemart. 2005. Gaps promote plant diversity in beech forests, North Vosges, France. Ann. For. Sci., 62: 429-440.

Del GenIO, A.D., M. YAO, AND J. JONAS. 2007. Will moist convection be stronger in a warmer climate? Geophys. Res. Lett., 34.

Della-BiancA, L. AND D.E. BECK. 1985. Selection management in southern Appalachian hardwoods. South. J. Appl. For., 9(3): 191-196.

Duchesne, L., R. Ouimet, And D. Houle. 2002. Basal Area Growth of Sugar Maple in Relation to Acid Deposition, Stand Health, and Soil Nutrients. J Environ Qua, 31(5): 1676-1683.

Ellsworth, D.S., and P.B. Reich. 1992. Water relations and gas exchange of Acer saccharum seedlings in contrasting natural light and water regimes. Tree Physiol., 10(1): 1-20.

EVERHAM, E.M. AND N.V. BROKAW. 1996. Forest damage and recovery from catastrophic wind. Bot. Rev., 62: 113-185.

Fahey, R.T., B.C. Alveshere, J.I. Burton, A.W. D’Amato, Y.L. Dickinson, W.S. Keeton, C.C. Kern, A.J. Larson, B.J. Palik, K.J. Puettmann, M.R. Saunders, C.R. Webster, J.W. Atkins, C.M. Gough, And B.S. Hardiman. 2018. Shifting conceptions of complexity in forest management and silviculture. For. Ecol. Manag., 421: 59-71.

FRANKLIN, J.F. 1988. Structural and functional diversity in temperate forests, p: 166-175. In: Wilson, E.O. and F.M. Peter (eds.). Biodiversity. National Academies, Washington, D.C.

Graham, S.A. 1941. Climax forests of the Upper Peninsula of Michigan. Ecology, 22(4): 355-362.

Gregory, R.A. 1980. Annual cycle of shoot development in sugar maple. Can. J. For. Res., 10: 316-326. 
Hubert, E.E. 1918. Fungi as contributory causes of windfall in the Northwest. J. For., 16: 696-714.

Iverson, L., AND A. Prasad. 2001. Potential Changes in Tree Species Richness and Forest Community Types following Climate Change. Ecosystems, 4: 186-199.

JONES, E.W. 1945 The structure and reproduction of the virgin forests of the north temperate zone. NewPhytol., 44: 130-148.

JoneS, T.A. AND S.C. ThOMAS. 2007. Leaf-level acclimation to gap creation in mature Acer saccharum trees. Tree Physiol., 27: 281-290.

KÖRNER, C. 2005. An introduction to the functional diversity of temperate forest trees, p. 13-37. In: Scherer-Lorenzen, M., C. Körner, E.D. Schulze (eds.). Forest diversity and function. Ecological studies (analysis and synthesis), vol 176. Springer, Berlin, Heidelberg.

LEAHY, M.J. AND K.S. PREgITZER. 2003. A comparison of presettlement and present-day forests in northeastern lower Michigan. Am. Midl. Nat., 149(1): 71-89.

Loftis, D.L., AND C.E. McGeE (Eds.). 1993. Oak Regeneration: Serious Problems Practical Recommendations (Symposium Proceedings). Gen. Tech. Rep. SE-84. Asheville, NC: U.S. Department of Agriculture, Forest Service, Southeastern Forest Experiment Station. 319 p.

MARKS, P.L. AND S. GARDESCU. 1998. A case study of sugar maple (Acer saccharum) as a forest seedling bank species. J. Torrey Bot. Soc., 125(4): 287-296.

---- AND G. HITZHUSEN. 1999. Windstorm damage and age structure in an old growth forest in central New York. Northeast. Nat., 6(2): 165-176.

NowACKI, G.J. AND M.D. ABRAMS. 2008. The demise of fire and "mesophication" of forests in the eastern United States. BioScience, 58(2): 123-138.

Pederson, N., J.M. VARner, And B.J. PAliK. 2008. Canopy disturbance and tree recruitment over two centuries in a managed longleaf pine landscape. For. Ecol. Manag., 254: 85-95.

PEDRO, S.M., W. RAMmer, AND R. SeIDL. 2015. Tree species diversity mitigates disturbance impacts on the forest carbon cycle. Oecologia, 177: 619-630.

PicketT, S. 1980. Non-equilibrium coexistence of plants. J. Torrey Bot. Soc., 107: 238248.

Pierce, P., J. Bielecki, B. MahalaK, And D. Farnsworth. 1994. The Compleat 
Marker, Bill Botti, (ed.). Michigan Department of Natural Resources, Forest Management Division, Lansing.

Schaetzl, R.J., D.L. Johnson, S.F. BuRns, And T.W. Small. 1989. Tree uprooting: review of terminology, process, and environmental implications. Can. J. For. Res., 19.

Schulte, L.A. AND D.J. MladenOFF. 2005. Severe wind and fire regimes in northern forests: historical variability at the regional scale. Ecology, 86(2): 431-445.

---- AND T.R. Crow, L.C. Merrick, And D.T. Cleland. 2007.

Homogenization of northern U.S. Great Lakes forests due to land use. Landsc. Ecol., 22: 1089-1103.

SCHMIDT, R.A. 1978. Diseases in forest ecosystems: the importance of functional diversity, p: 287-315. In: Horsfall, G. and E.B. Cowling (eds.). Plant disease: an advanced treatise: how disease develops in populations. Elsevier, Cambridge, MA.

STEARNS, F. 1990. Forest history and management in the northern Midwest, p. 109-122. In: Sweeney, J.M. (ed.). Management of dynamic ecosystems. North Central Section, The Wildlife Society, West Lafayette, IN.

WaLters, J.W. 1964. Lakes States Forest Experiment Station. The cause of maple blight in the Lake States. Res. Pap. LS-10. St. Paul, MN: U.S. Department of Agriculture, Forest Service, Lakes States Forest Experiment Station; 15 p.

Webster, C.R., Y.L. Dickinson, J.I. Burton, L.E. Frelich, M.A. Jenkins, C.C. Kern, P. RAYMOND, M.R. SAUNDERS, M.B. WALters, AND J.L. WiLlis. 2018. Promoting and maintaining diversity in contemporary hardwood forests: Confronting contemporary drivers of change and the loss of ecological memory. For. Ecol. Manag., 421: 98-108.

White, M. AND D.J. MladenOFF. 1994. Old-growth forest landscape transitions from pre-European settlement to present. Landsc. Ecol., 9(3): 191-205.

Woods, K. 2000. Dynamics in late-successional hemlock-hardwood forests over three decades. Ecology, 81(1): 110-126.

Zhang, Q., K.S. Pregitzer, AND D.D. ReED. 1999. Catastrophic disturbance in the presettlement forests of the Upper Peninsula of MI. Can. J. For. Res., 29: 106-114.

Zhang, Q., K.S. Pregitzer, And D.D. ReED. 2000. Historical changes in the forests of the Luce District of the Upper Peninsula of Michigan. Am. Midl. Nat., 143(1): 94110 . 


\section{Observations of light, microclimate, and coarse woody debris volumes in wind-formed gaps in Acer saccharum hardwoods with and without single tree selection}

\subsection{Abstract}

Light from the sun changes how plants grow and how animals communicate and see the world. Environmental geometry alters the intensity of transmitted light by reflecting, obscuring and altering angles across spectral chroma. In northern Michigan forests, seedling growth has largely concluded by late summer; as daylight shortens and air temperatures decline, bud formation for next year's growth commences. This study seeks to document microclimatic conditions in small wind-formed gaps and forest interior in second growth northern hardwoods dominated by sugar maple (Acer saccharum). Late summer recordings of photosynthetically active radiation (PAR), air temperature and humidity, soil temperature and moisture, and coarse woody debris volumes were compared across gap and interior habitats in second-growth northern hardwood forests, and between adjacent stands with and without prior single tree selection harvest. Microclimatic factors were more similar by management type than habitat. Gaps and interior in the stand with previous single tree selection were cooler and more humid with warmer and drier soils than in the adjacent unmanaged stand. Coarse wood volumes were more similar by disturbance type, with more than $40,000 \mathrm{~kg}^{-1} \mathrm{ha}^{-1}$ coarse wood in storm gaps. PAR was influenced by both management and disturbance history. The storm gap in the harvested stand received twice as much PAR as the gap in unmanaged forest, despite similar dimensions of 215 .and $218 \mathrm{~m}^{2}$, respectively. In contrast, the forest interior of unmanaged forest received more PAR than the managed forest interior. 


\subsection{Introduction}

Light energy touches nearly every aspect of forest life from inciting basic photosynthetic chemical reactions to influencing ecological relationships between species and forest development and structure. In turn, forest structure influences the quality of light transmitted in different habitat types (Endler 1993). Structurally diverse forests support a diversity of light environments and spatially varied microclimates. Sugar maple dominated northern hardwoods have been cited for maintaining low compositional diversity within seedling regeneration. Yet, sugar maple thrive in a diversity of light environments. Thus, low species diversity does not entail low structural diversity. A canopy dominated by a single species can create heterogeneous light environments as light transmittance and reflectance vary across different sizes of crowns and trunks, basal area distributions, understory development, and leaf canopy architecture.

We accept that by creating different canopy openings via tree harvest, we can manipulate the species composition of regenerating plants. Most of this control is attributed to manipulation of light levels. Yet, a better understanding of the implications of forest canopy structure on microsite variation in air temperature, soil moisture, and soil temperature, will aid efforts to effectively develop ecologically-based forest management practices. Mimicking natural disturbance regimes and detailing the characteristics and derivations of locally important niche habitats is fundamental to effectively balance economic demands of timber productivity with other natural resource management objectives. Treefall and gap formation drive the regeneration of different tree and shrub species by creating niche microclimates and topographies, and via the liberation of light and other resources and improved structural heterogeneity (Abe et al. 1995; Hanson and Lorimer 2007). Light heterogeneity also plays a key role in seedling regeneration in forest interior, where crown architecture of the dominant species dictate shade depth and sunflecking (Canham et al. 1994).

Heterogeneous light environments are created by complex forest structure, with trees of varying sizes, species, and distributions. Light reaches objects in the forest either directly, from the sun, or diffusely, from passing through a cloud or reflecting from illuminated surfaces like leaves, trunks, or the forest floor. The angle (azimuth) of the sun 
and atmospheric conditions affect an object's color intensity and saturation (chroma). Furthermore, the size and arrangement of these objects around an open patch in the forest, affects the quality and quantity of transmitted light. For example, the irradiance of direct light is several orders of magnitude greater than that of diffuse light.

The primary disturbances in northern hardwood forests responsible for designing canopy gap mosaics are windfall and harvest. Single tree selection mimics small scale disturbances such as single tree mortality or small group tree fall (Emborg et al. 2000). However, greater frequency of small gaps dispersed throughout single tree selected forests may increase overall light levels, as much of the understory will be gap-adjacent in one or more directions. On the other hand, adjacent canopy exerts strong influence on the microclimate of gap habitats (Denslow 1987), as surrounding trees intercept light, seed-in, and over time, constrict the gap opening through branch extensions and sexual reproduction. The influence of canopy trees on climate extends beyond microsite variation between gaps and interior. Arisen as a single-age class from unprecedented clear cutting of hardwoods and pine and now approaching 120 years of age, the dense maple canopies create microclimatic conditions that outwardly alter the landscape by cooling and humidifying in a process coined 'mesophication' (Nowacki and Abrams 2008). In addition to influencing climatic stability of the snow belt, the even-aged structure and single-species dominance of maple in the western Upper Peninsula can influence compositional and structural diversity of succeeding forest types.

Seven monitoring sites were established in mid-summer 2019 to measure microclimate variability across a gradient of canopy openness in both unmanaged second growth forest stands and stands experiencing regular single tree selection harvest.

The author hypothesizes that:

1. Photosynthetically active radiation (PAR) will be more intense in canopy gaps than forest interior and greater in managed than unmanaged forest

2. Diurnal variation of air and soil temperature will have greater magnitude in canopy gaps than forest interior and be greater in managed than unmanaged forest 


\subsection{Study Site}

The study site was located within the Copper Country State Forest in southern Houghton County, Michigan $\left(46^{\circ} 51^{\prime} \mathrm{N}, 88^{\circ} 53^{\prime} \mathrm{W}\right)$. Forest type was mixed northern hardwoods dominated by sugar maple 37 to $47 \mathrm{~cm}$ in diameter. The canopy also included minor components of white ash (Fraxinus americana), northern red oak (Quercus rubra), American basswood (Tilia americana), red maple (Acer rubrum), eastern hemlock (Tsuga candansis), and white pine (Pinus strobus). Black cherry (Prunus serotina), ironwood (Ostrya virginiana) and balsam fir (Abies balsamea) were also present in the understory. Forests in the study area are predominantly second-growth, after intense timber harvests of the late $19^{\text {th }}$ and early $20^{\text {th }}$ century.

Microclimate sensors were distributed throughout two adjacent stands located east (forest compartment stand 'FCS' 55-12) and west (FCS 54-13) of Pike Lake Rd (Figure 1). FSC 54-13 was harvested by single tree selection methods 11 years prior to this study, and will be referred to in the text as a managed forest. FSC 54-12 has had no harvest for at least fifty years and will be referred to in the text as unmanaged forest. Monitored sites in the managed forest are presented in warm color tones, red to yellow, in figures and referred to by names starting with the letter "C" (Cherry Gap, Chickaree Interior, Conus Interior). Sites in the unmanaged forest are presented in cool color tones, green to blue, with names starting with the letter "B" (Belle Gap, Big Pine Gap, Back Interior, and Branch Interior).

In both the managed and unmanaged stands, light transmittance, air temperature, and humidity were measured from August 1 to August 17 in a small gap (125-220 $\left.\mathrm{m}^{2}\right)$ and interior forest habitat locations. Soil temperature and moisture were measured during an extended study period (July 12 to August 12) in another pair of gap and interior sites in both stands. One gap, 'Cherry Gap' was monitored for both light/air and soil microclimate. Seedling density was measured at all monitoring sites by the methods described in chapter 2 .

Coarse woody debris was surveyed at the 3 wind gaps and 4 interior sites described above, as well as in an additional 7 wind gaps and 7 interior sites in nearby forest stands with and without recent harvest management (Appendix B Table 1.1). 


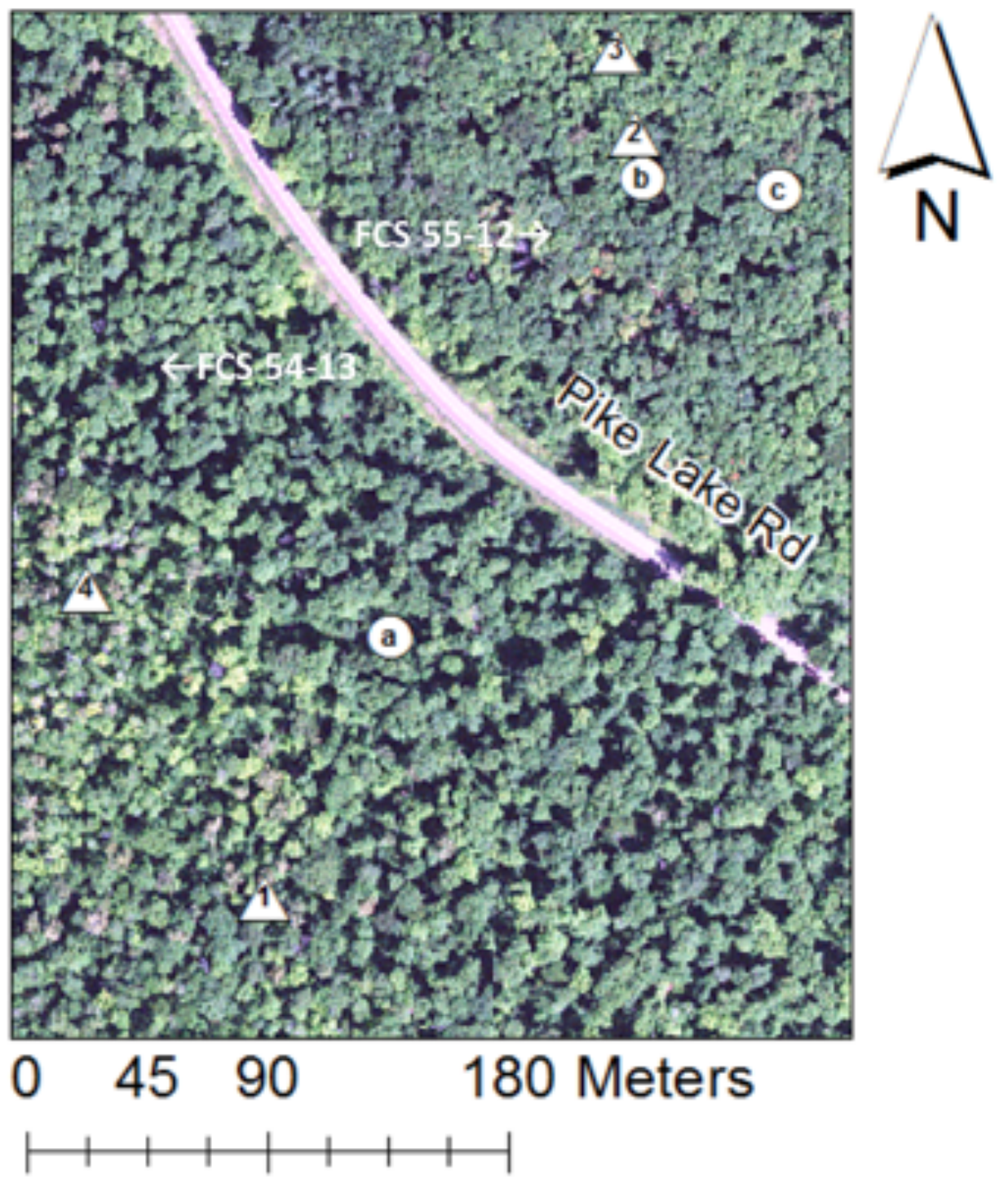

Figure 4.1. Microclimate monitoring sites in unmanaged (FCS 55-12) and managed (FCS 54-13) mixed northern hardwood stands. Small gaps are labeled with letters and circles, forest interior with numbers and triangles.

\subsection{Instrumentation and Measurements}

PAR light, air temperature and relative humidity were measured with Specmeter (C) Watchdog (C) weather monitoring stations (Spectrum Technologies, Aurora, IL) positioned approximately 1.5 meters above the forest floor. A Quantum Light 6 Sensor 
Bar (accuracy $\pm 5 \% \mu \mathrm{mol} \mathrm{m}^{-2} \mathrm{~s}^{-1}$ ) recorded photosynthetically active radiation (PAR, $400-700 \mathrm{~nm}$ ). Air temperature and humidity were measured with Digital

Temperature/RH Sensors enclosed in an Aspirated Radiation Shield (accuracy $\pm 0.2^{\circ} \mathrm{C}$ and $\pm 2 \%$ at $25^{\circ} \mathrm{C}$ ). Soil temperature and volumetric water content were measured with Decagon 5TM VWC + Temp sensors (accuracy $\pm 0.1^{\circ} \mathrm{C}$ and $\pm 0.03 \mathrm{~m}^{3} / \mathrm{m}^{3}$ volumetric moisture in mineral soils). Each soil monitoring location had 5 probes positioned near the soil surface $(<10 \mathrm{~cm}$ depth) at site center and at 3 meters in each cardinal direction.

CWD volume was determined by the "triangular transect" method described by Reed and Mroz (1997). From the center node at each microclimate monitoring location, a $20 \mathrm{~m}$ transect was set along the ground in the northern direction. Two additional $20 \mathrm{~m}$ transects are set from either end of the first transect to form a triangle. Along this transect, all intersecting coarse woody debris $>5 \mathrm{~cm}$ diameter was measured for diameter at the intersecting location and assigned a decay class from 1 to 4 in order of progressing decomposition using the categories and hardwood densities described by Duvall and Grigal (1999). CWD volume ( $\mathrm{m}^{3} / \mathrm{ha}$ ) was calculated at each location using an equation adapted from Delisle et al. (1988) as follows:

$V=\left(\pi / 2^{*} \mathrm{~L}\right) \sum \pi(\mathrm{d} / 2)^{2}$

Where:

$\mathrm{d}=$ diameter $(\mathrm{cm})$

$\mathrm{L}=$ length of transect $(\mathrm{m})=60 \mathrm{~m}$

Dry mass per hectare was then calculated as:

$$
M=V \times D \times 1000
$$

Where:

$\mathrm{M}=$ dry mass per hectare $(\mathrm{kg} / \mathrm{ha})$

$\mathrm{V}=$ volume estimated above as $\mathrm{m}^{3} / \mathrm{ha}$

$\mathrm{D}=$ mean density $\left(\mathrm{g} / \mathrm{cm}^{3}\right)$ assigned by decay class from Duvall and Grigal (1999) 


\subsection{Results}

Daily mean air temperatures cooled gradually from August 1 to August 17, 2019 (Figure 4.2), following the normal climate pattern of the study area as day length declined from $14 \mathrm{~h} 52 \mathrm{~min}$ to $14 \mathrm{~h} 7 \mathrm{~min}$. Precipitation was below average; a total of $14.73 \mathrm{~mm}$ rain during the study period, average for the month of August (1981-2010) is $79.0 \mathrm{~mm}$. From August 6 - August 13 the study area was under 'abnormally dry' conditions (US Drought Monitor).

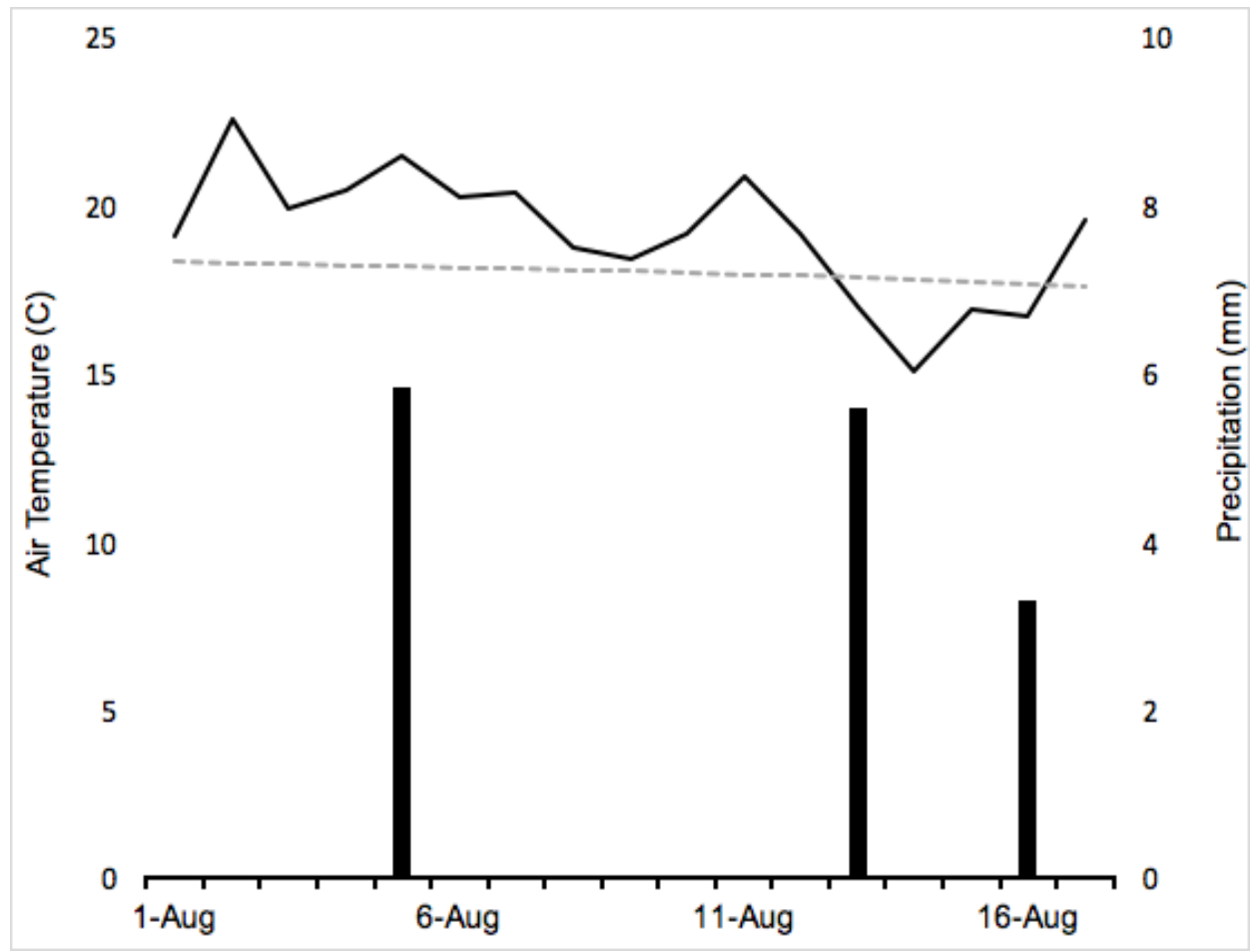

Figure 4.2. Temperature and precipitation record for the study period (1 -17 August 2019). Dashed line represents the study area temperature normal (1981-2010). Daily weather data for Pelkie, MI Sourced from Western Regional Climate Center.

\subsubsection{PAR intensity}

PAR intensity in the small canopy gaps far exceeded that of forest interior (Figure 4.3A). Average daily PAR was $6.2 \mathrm{~mol}^{-1} \mathrm{~m}^{-2}$ day $^{-1}$ in the managed forest's wind gap and 3.7 in the unmanaged forest's gap (Figure 4.3B). Unexpectedly, daily light increment was 
significantly greater in the unmanaged forest interior $\left(\mathrm{M}=0.9 \mathrm{~mol}^{-1} \mathrm{~m}^{-2}\right.$ day ${ }^{-1}, \mathrm{SD}=$ $0.39)$ than in the managed forest interior $(\mathrm{M}=0.2, \mathrm{SD}=0.15)(\mathrm{p}<0.001)$. Maximum daily PAR was rarely greater than $100 \mu \mathrm{mol} \mathrm{m}^{-2} \mathrm{sec}^{-1}$ in forest interior (Figure 4.4C).

Maximum daily PAR exceeded $700 \mu \mathrm{mol} \mathrm{m}{ }^{-2}$ on more than half of study days in the wind gap within managed forest, compared to $200 \mu \mathrm{mol} \mathrm{m}{ }^{-2}$ in the unmanaged forest wind gap. Diurnal variation in PAR displayed unique patterns across the four forest habitats (Figure 4.3D). In the managed forest gap, a sharp midday depression in PAR occurred nearly every day, creating dual peaks in light intensity at 11:00 and 14:00. In the unmanaged gap, a single peak light occurred on average at 12:00 each day. The two gaps received radiation for 11-15 hours per day between the hours of 0700 and 2100. The forest interiors received radiation for 8-13 hours per day, with sunlight reaching the sensor later in the morning and receding earlier in the afternoon.

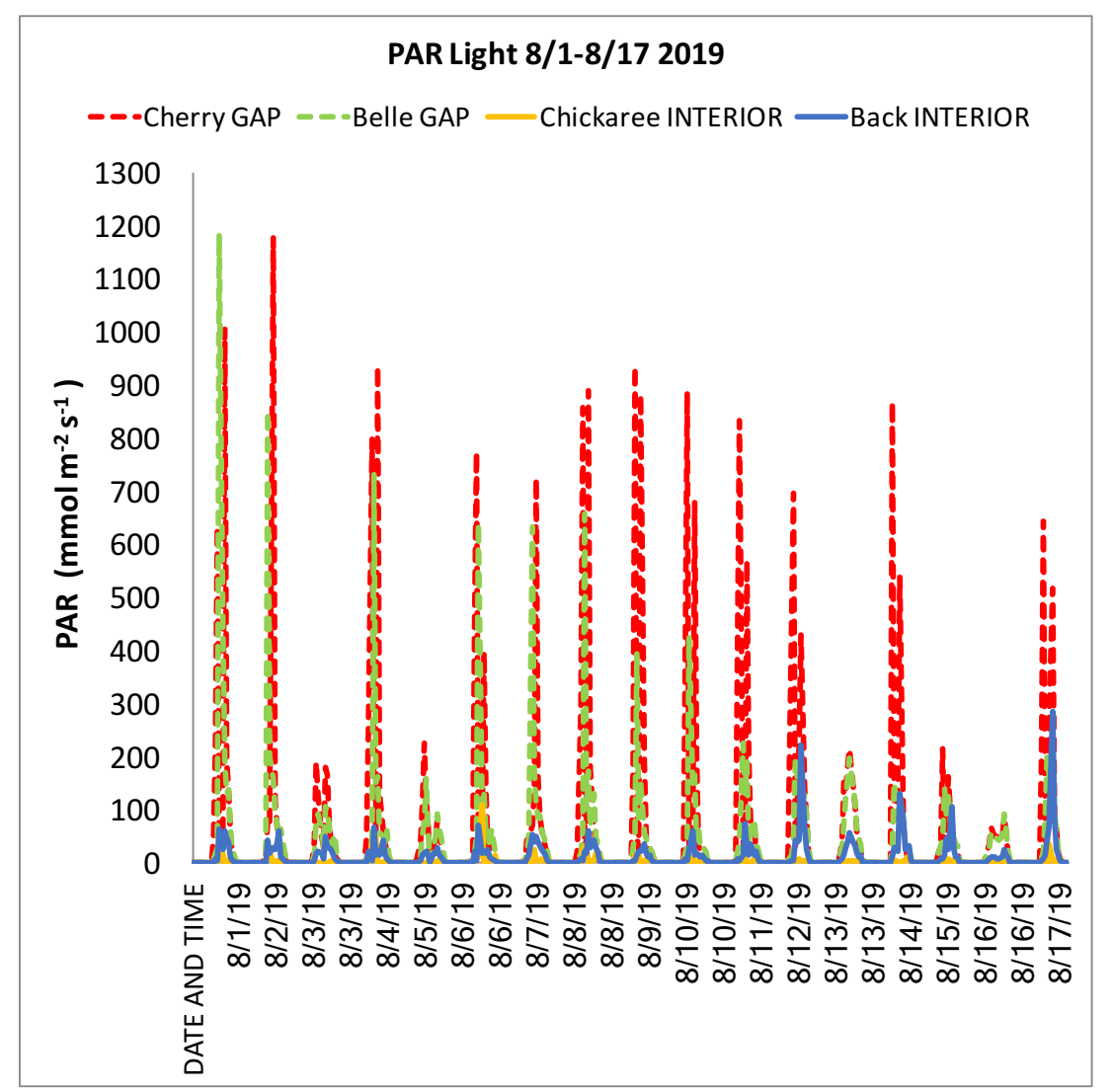

Figure 4.3. (A) Hourly PAR in gap and forest interior of managed and unmanaged second growth northern hardwood stands 


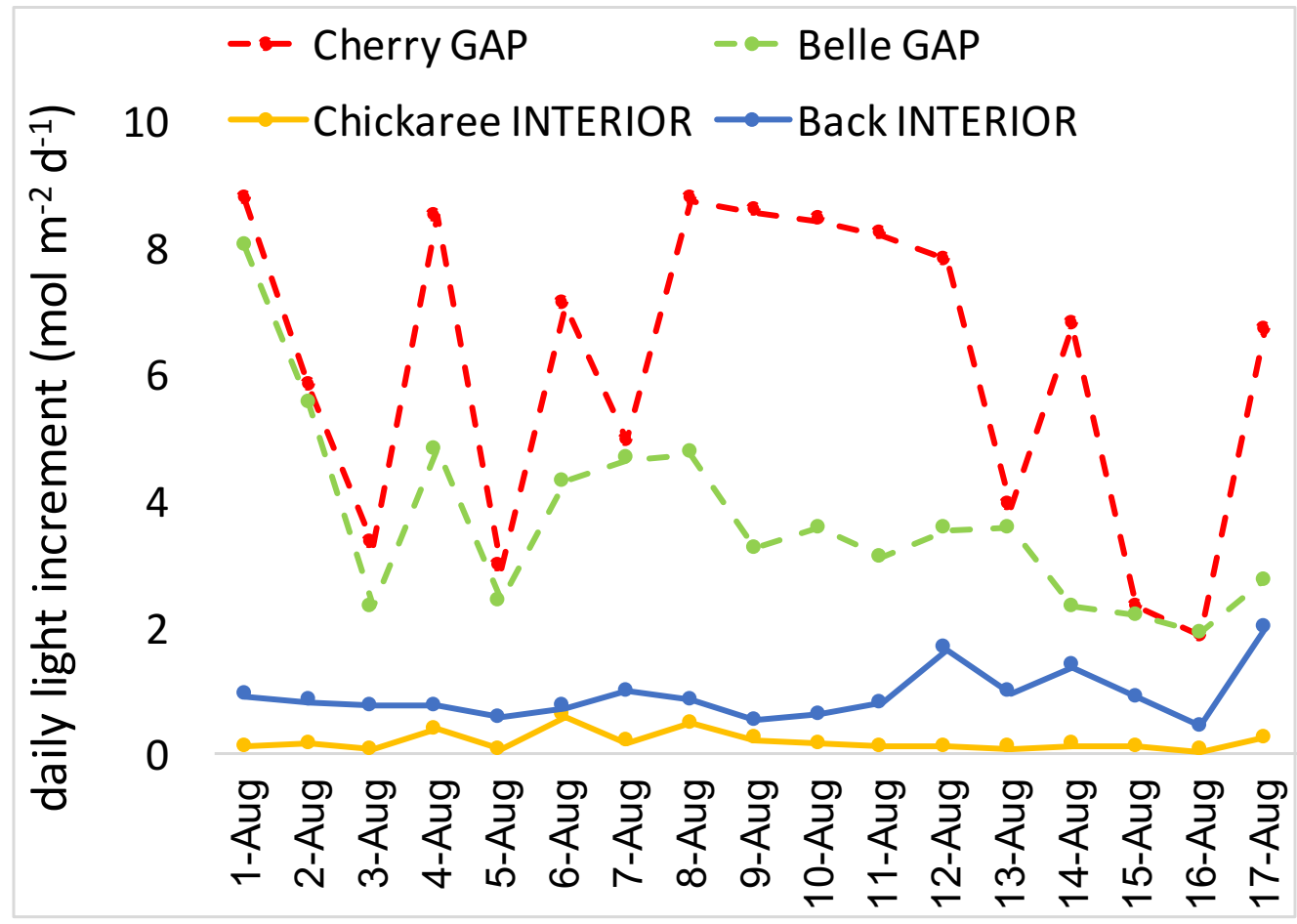

Figure 4.3. (B) Mean daily PAR in wind gap and forest interior of managed (Cherry and Chickaree) and unmanaged (Belle and Back) second growth northern hardwood stands

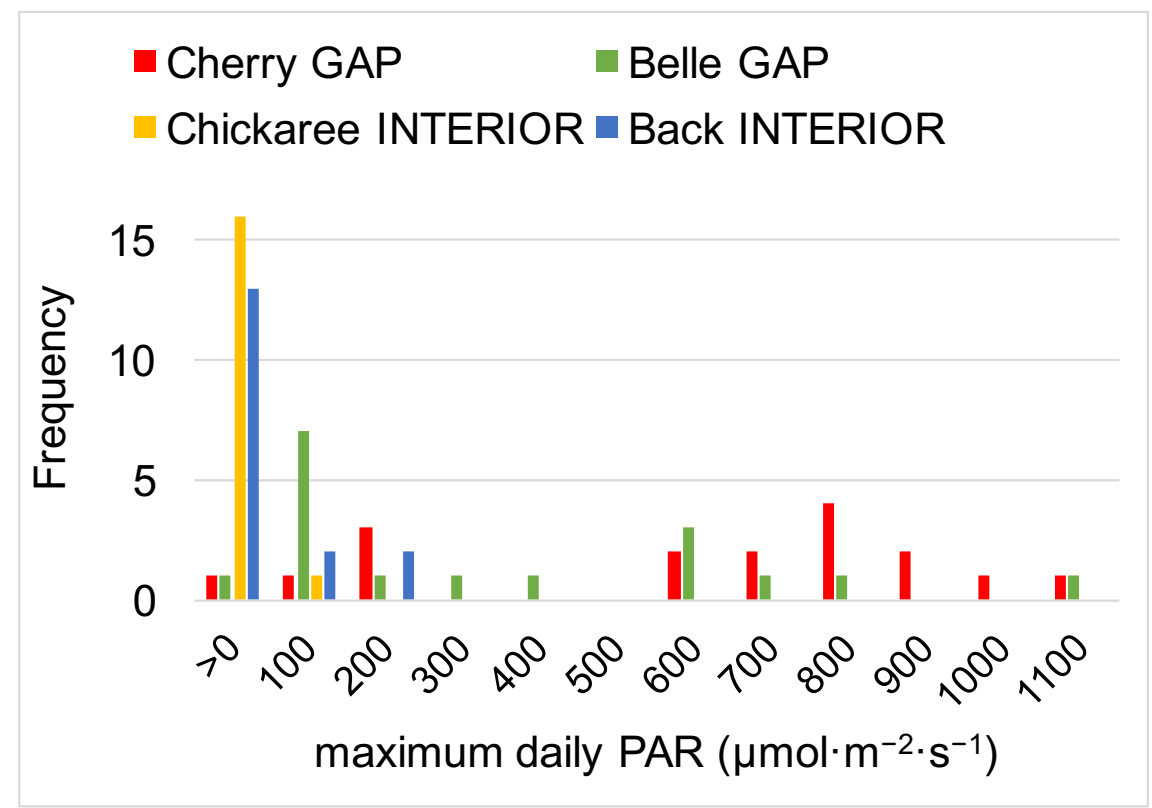

Figure 4.3. (C) Maximum daily PAR frequency in gap and forest interior of managed and unmanaged second growth northern hardwood stands 


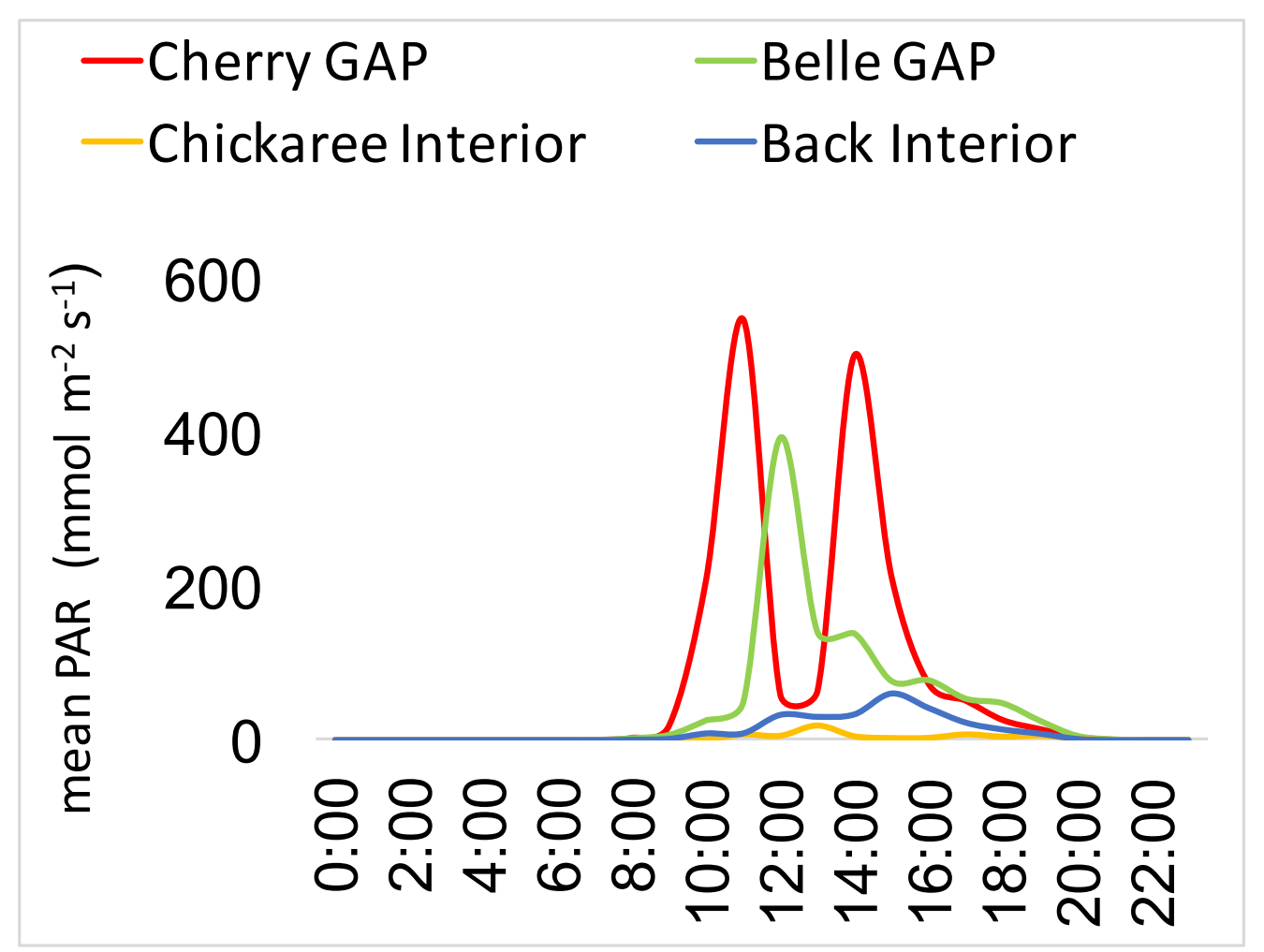

Figure 4.3. (D) Diurnal variation in PAR (B) in gap and forest interior of managed and unmanaged second growth northern hardwood stands

\subsubsection{Air temperature and humidity}

Hourly air temperature ranged 7.9 to $27.4{ }^{\circ} \mathrm{C}$. Air temperature declined over the study period in correspondence with the season (Figure 4.4A). The unmanaged stand was warmer than the managed stand by approximately $0.4{ }^{\circ} \mathrm{C}$. The managed canopy gap had the widest variation in daily air temperature, reaching cooler conditions at night and warmer temperatures in the mid-afternoon (Figure 4.4B). A slight dip in air temperature in Cherry Gap around noon coincides with the midday depression in PAR at that site. The managed forest interior had the least diurnal variation in air temperature and humidity, and was the coolest and most humid location during the day. There was less variation in air temperature between the interior and gap habitats of unmanaged forest, than in the managed stand. Relative humidity was highest, nearing $100 \%$ saturation at night, drying to $50-70 \%$ by later afternoon. Humidity was higher in managed forest and lower in the adjacent unmanaged stand. 


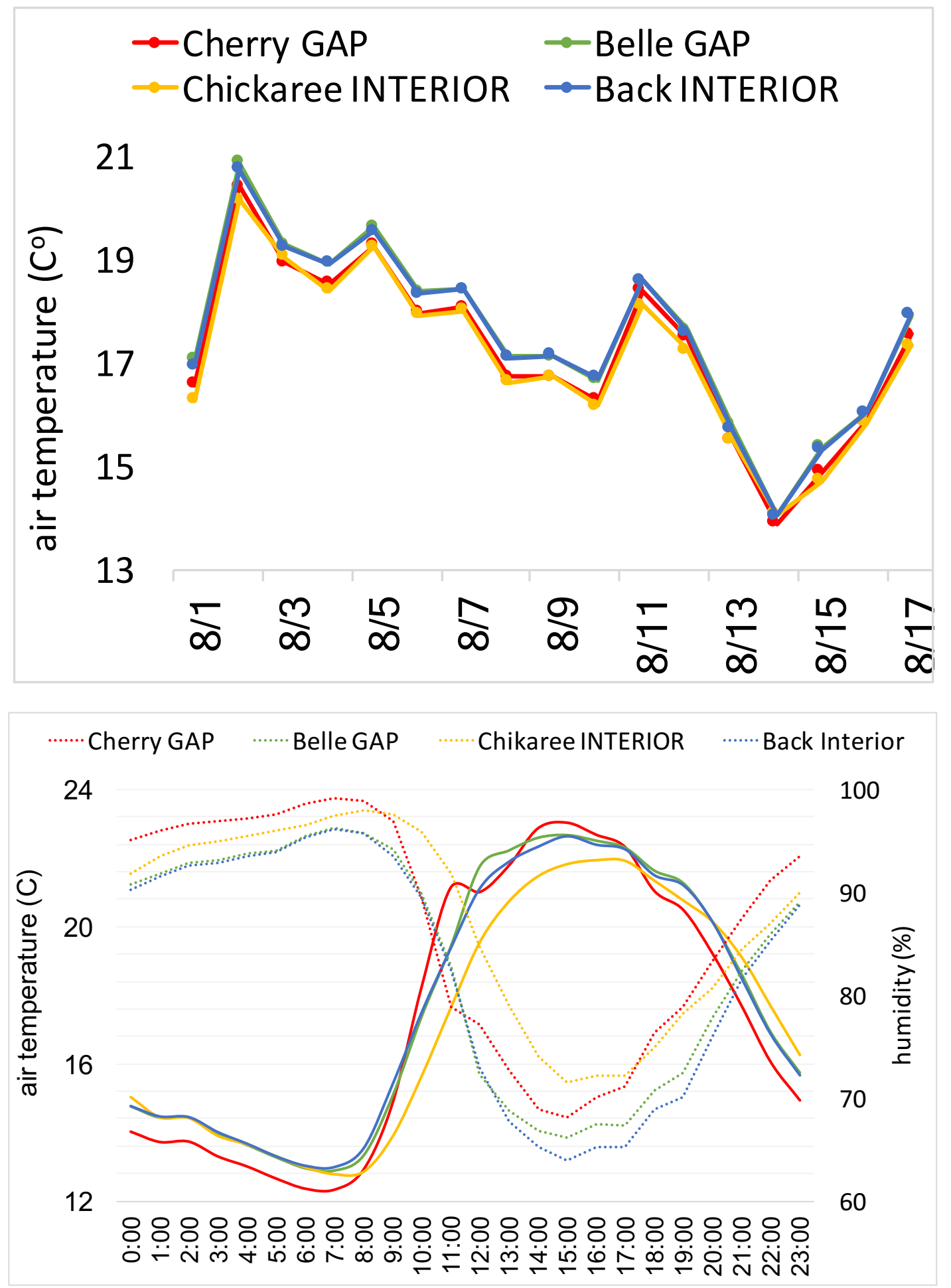

Figure 4.4. Mean daily air temperature (A) and diurnal variation in temperature and humidity (B) in gap and forest interior of managed and unmanaged second growth northern hardwood stands. Solid lines represent temperature and stippled line humidity. 


\subsubsection{Soil temperature and water content}

Soil temperatures were recorded in the range of 11.3 to $24.7{ }^{\circ} \mathrm{C}$. The cooling trend from $8 / 2$ to $8 / 12$ in soil temperature closely aligned with trends in air temperature (Figure 4.5A). In contrast to air temperature, soil temperature was warmer in managed forest than in unmanaged by an average of $3.5{ }^{\circ} \mathrm{C}(\mathrm{SD}=0.21)$. Site differences in soil temperature were most pronounced in the daytime (Figure 4.5B). Differences in soil temperature were inconsistent between gaps and forest interior, and were more similar between management type. Soil moisture measurements ranged from 0.08 to $0.39 \mathrm{~m}^{3} / \mathrm{m}^{3}$. Soil moisture peaked in association with five discrete rain events observed between 7/12 8/12 (Figure 4.6). The managed forest gap had the lowest soil moisture, but also had the greatest rate of soil moisture increase during rain events.

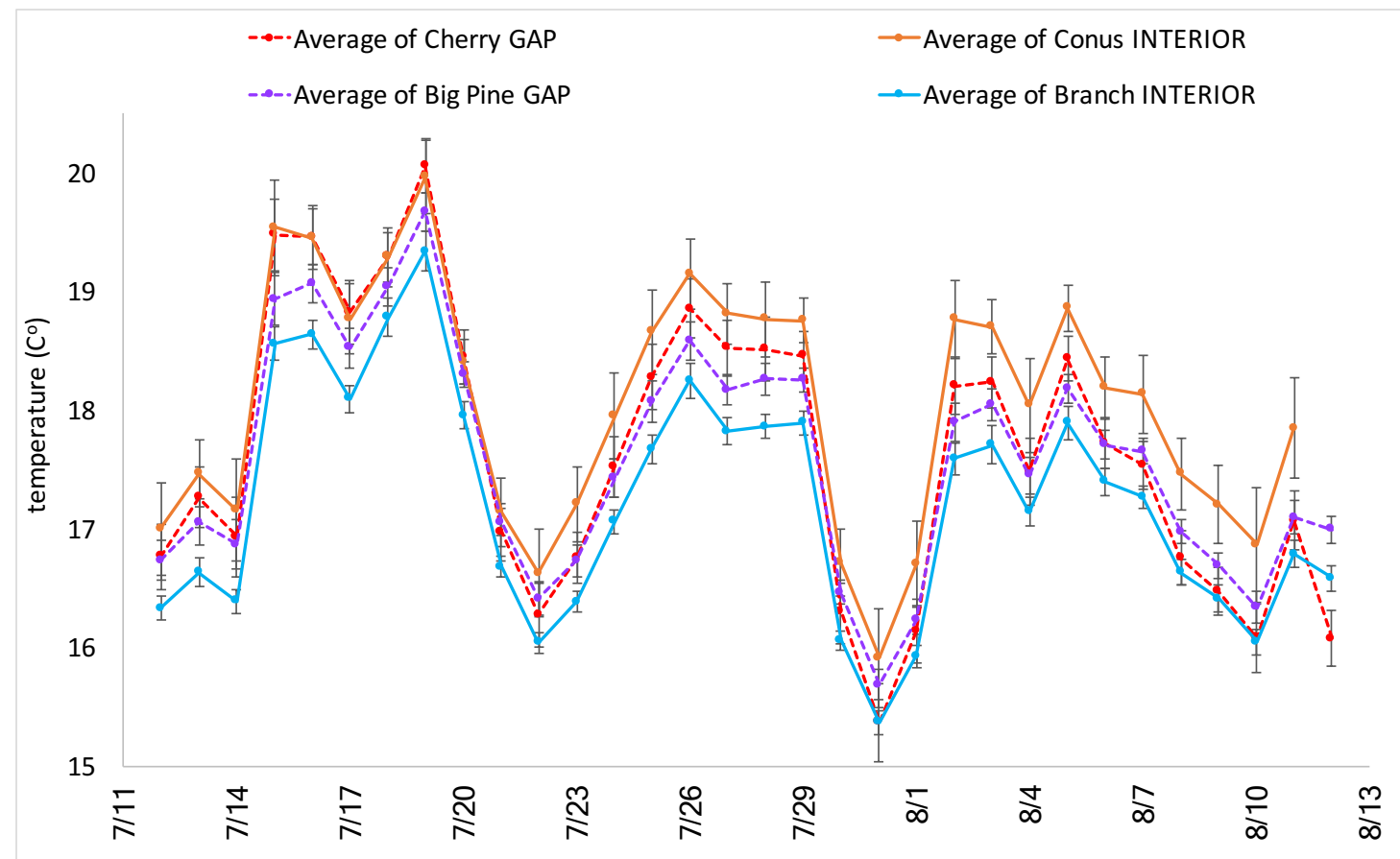

Figure 4.5. (A) Average daily soil temperature in small gap and forest interior of managed and unmanaged second growth northern hardwood stands. Error bars represent mean hourly SE. 


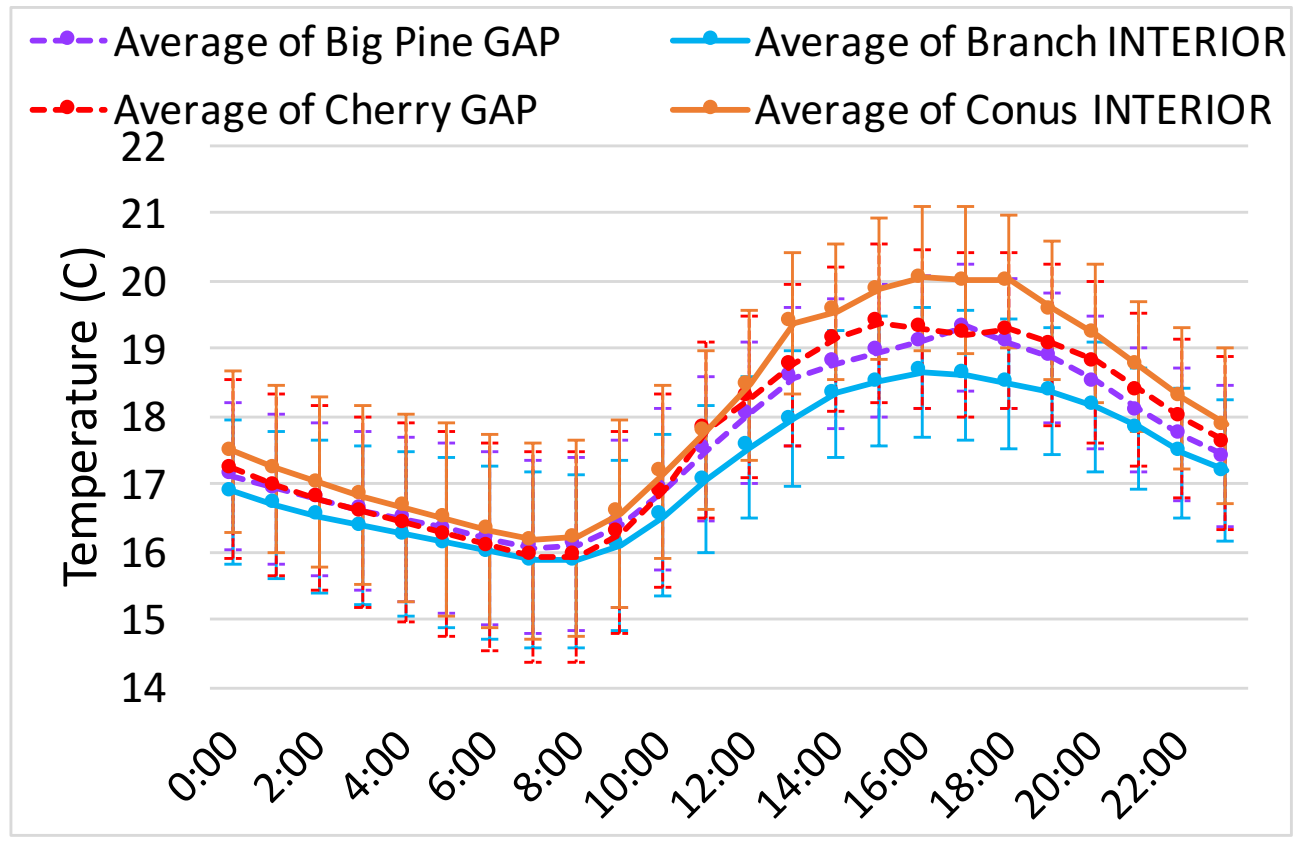

Figure 4.5. (B) Diurnal range (B) soil temperature in small gap and forest interior locations. Error bars represent standard deviation of hourly mean.

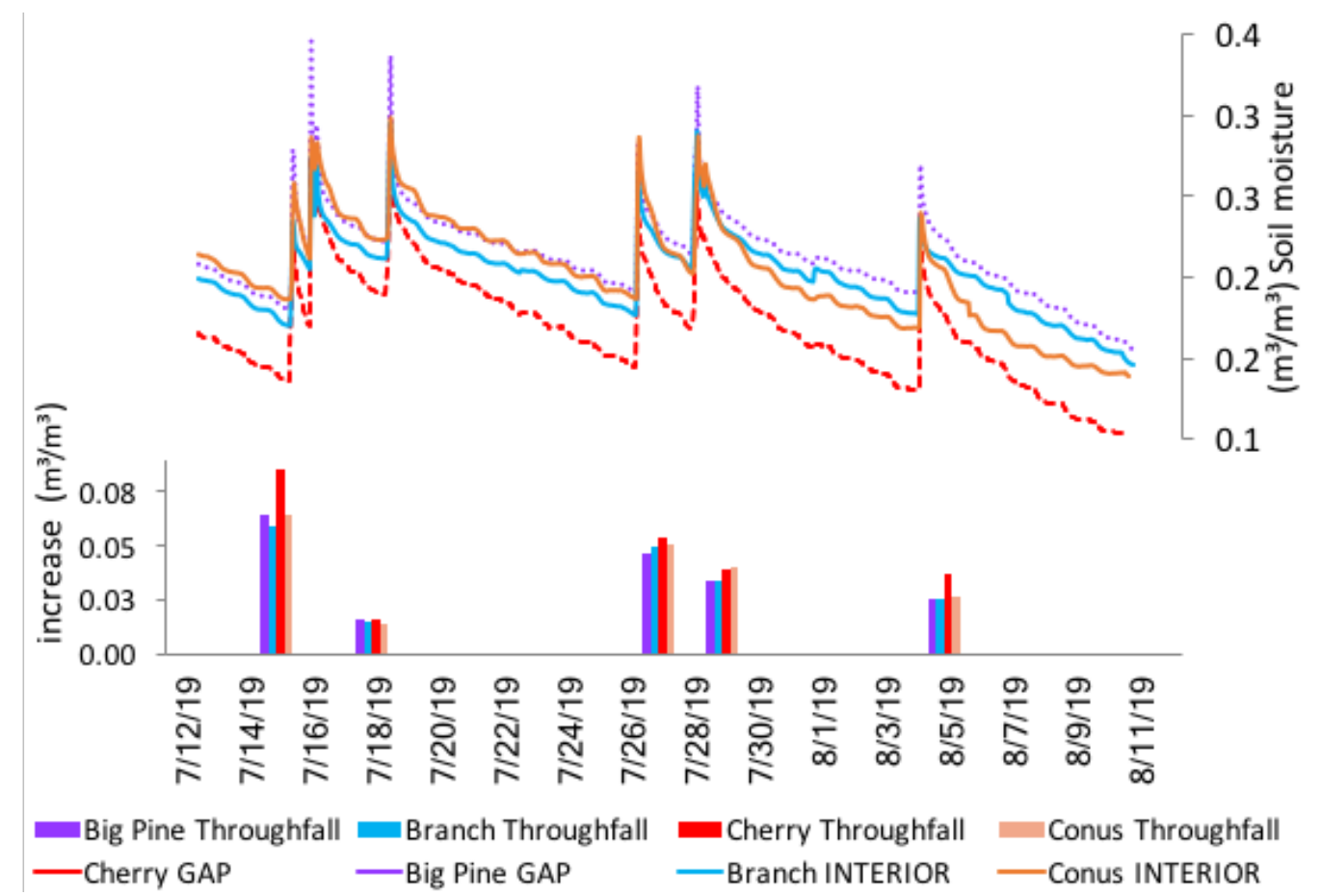

Figure 4.6. Hourly soil moisture trend (volumetric water content, $\mathrm{m}^{3} / \mathrm{m}^{3}$ ) and rate of increase during pulse rain events (bars) 


\subsubsection{Coarse woody debris in wind-formed gaps and forest interior with and without prior single tree selection harvest}

The majority of coarse wood surveyed was between 5 and $14 \mathrm{~cm}$ in diameter at point of intersection with the transect (Figure 4.8). CWD in wind gaps at the managed site were the most abundant and varied most widely in size. The largest documented CWD was observed in wind gaps in unmanaged sites, up to $54 \mathrm{~cm}$ in diameter. There was greater CWD mass $\left(\mathrm{kg}^{-1} \mathrm{ha}^{-1}\right)$ in wind gaps compared to forest interior (ANOVA with post-hoc Tukey $(\mathrm{F}(1,17)=6.35, \mathrm{p}<0.001)$ (Figure 4.9). Previous harvest and wind disturbance had an effect on CWD volume, as there was a significantly greater CWD volume $\left(\mathrm{m}^{-3} \mathrm{ha}^{-1}\right)$ in wind formed gaps with previous harvest, compared to forest interior with no previous harvest (ANOVA with post-hoc Tukey $(\mathrm{F}(1,17)=4.76, \mathrm{p}=.035$ ) (Figure 4.10).

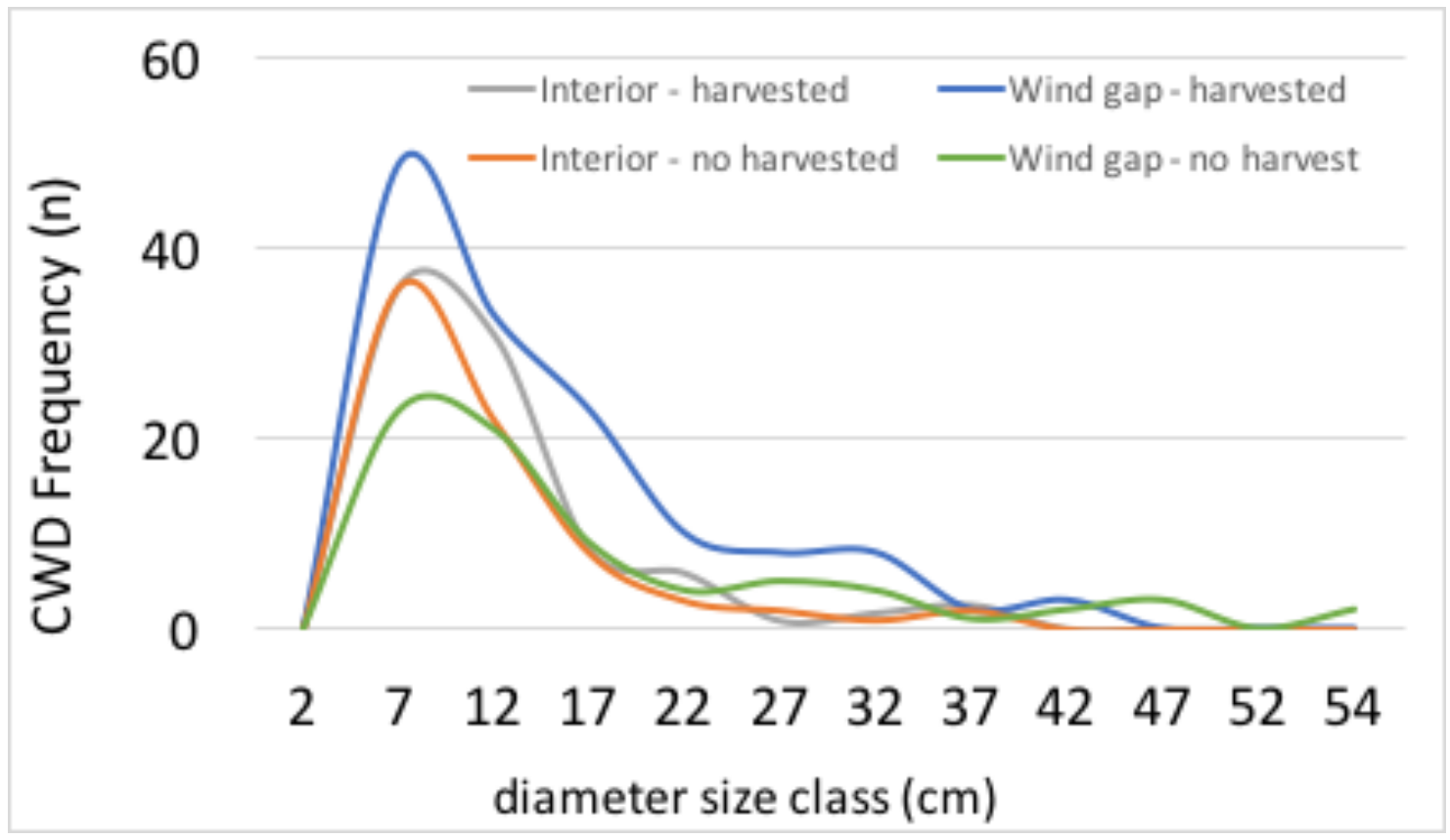

Figure 4.8. Coarse wood counts by diameter class in managed and unmanaged second growth northern hardwood stands. 


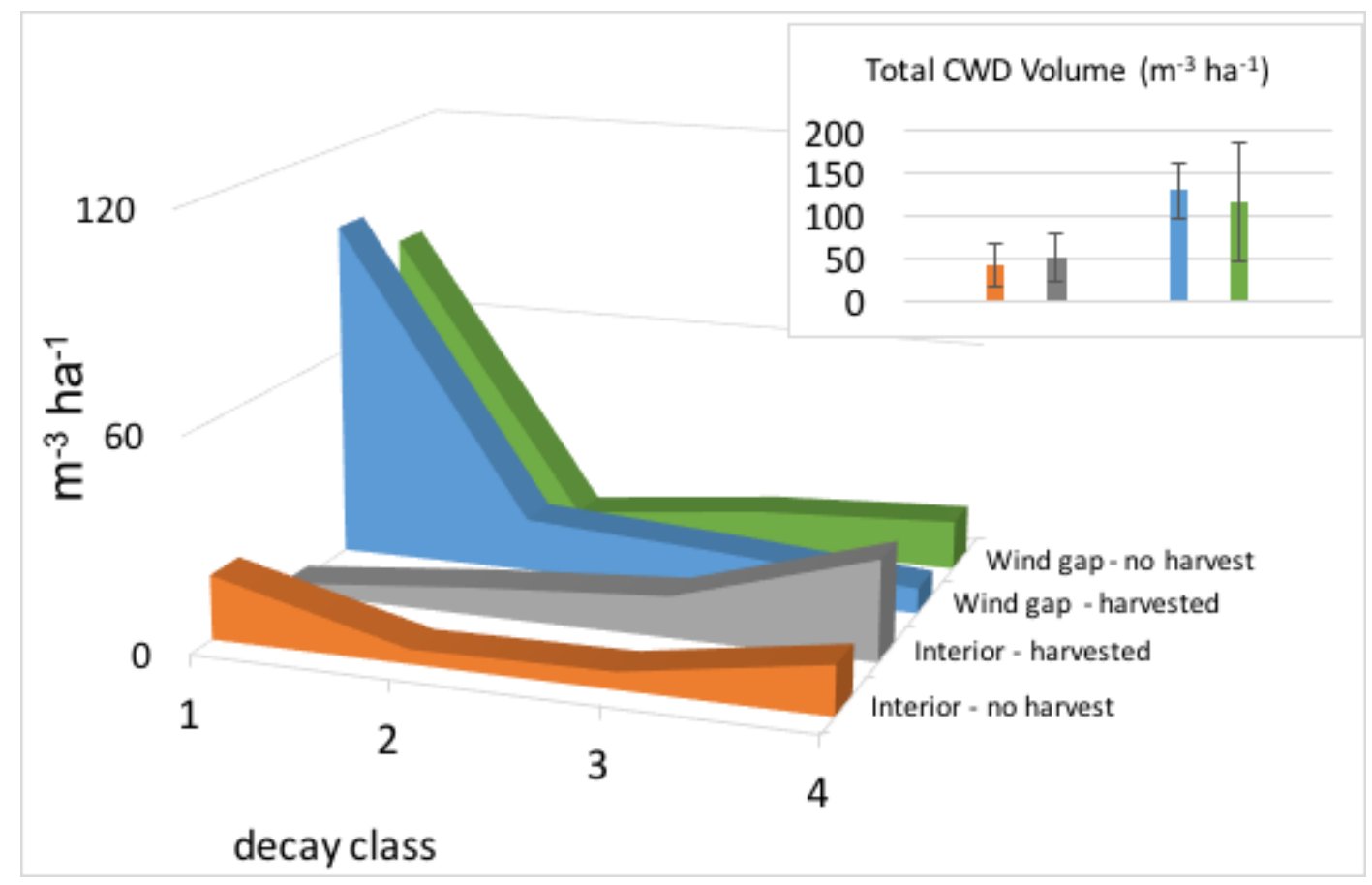

Figure 4.9 Coarse woody debris volume by decay class

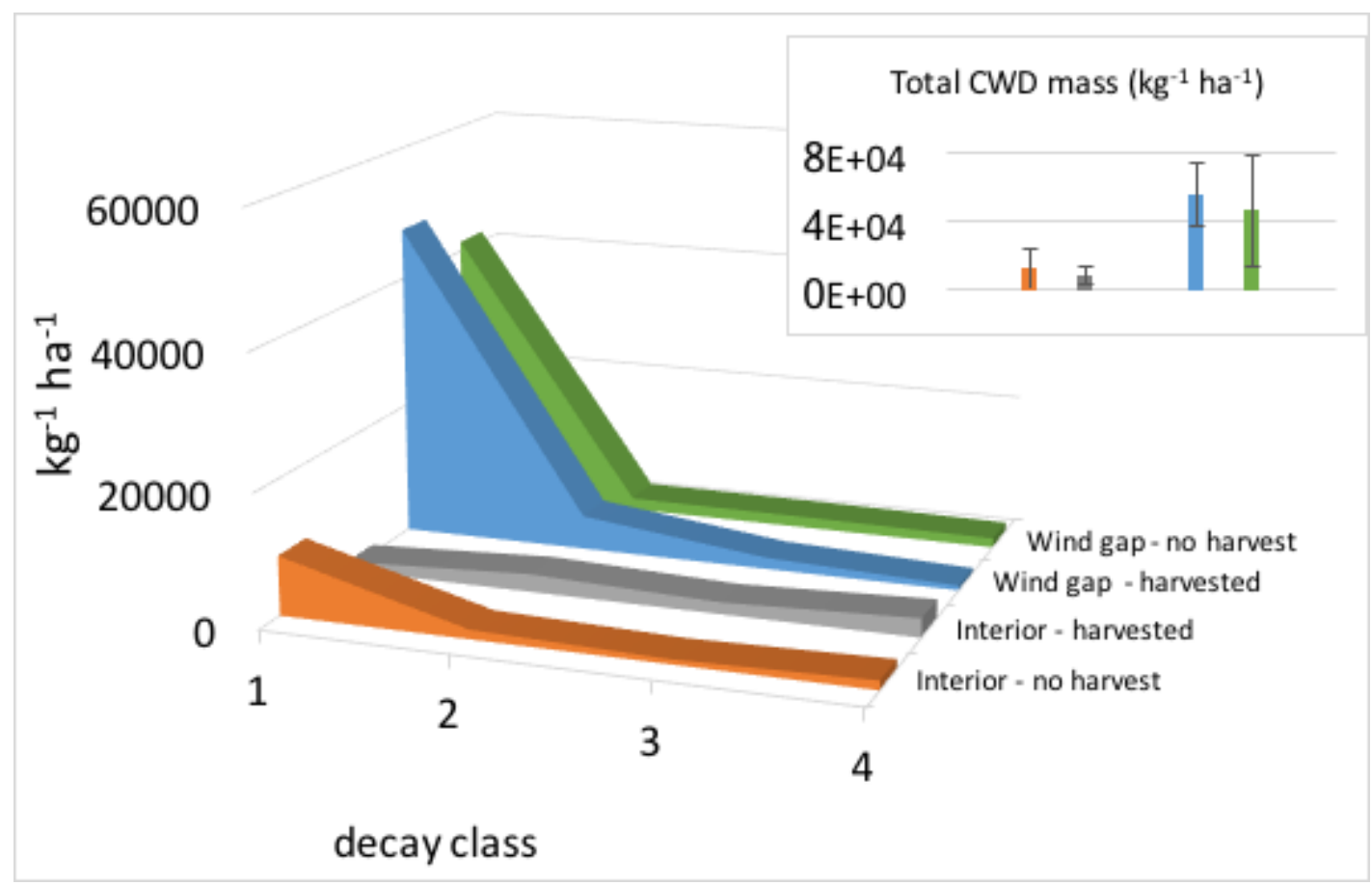

Figure 4.10 Coarse woody debris mass (dry weight) by decay class 


\subsection{Discussion}

As expected, small gap environments transmitted substantially more PAR, with maximum daily PAR exceeding $1000 \mu \mathrm{mol} \mathrm{m}^{-2} \mathrm{~s}^{-1}$, than in forest interior where maximum daily par rarely exceeded $100 \mu \mathrm{mol} \mathrm{m} \mathrm{m}^{-2} \mathrm{~s}^{-1}$. A midday depression in PAR observed in the largest gap was likely due to canopy interception of sunlight from trees immediately to the south of the gap; foliage tends to be clubbed at crown tops which can block the sun at an angle from higher in the sky (Ventre-Lespiaucq et al. 2018). Unexpectedly, more PAR reached the forest interior in unmanaged forest than in managed forest. Despite significantly more intense and longer duration daily light integrals in gaps, mean daily air temperature was cooler in the unmanaged forest than in managed forest. As hypothesized, diurnal variation in air temperature was greatest in the managed forest gap where the most exposure allowed light energy to warm the air during the day, and heat energy to escape at night.

Interestingly, soil temperature followed the opposite trend from air temperatures, and soils were warmer in unmanaged forest. This may indicate that heat transfer from air to soil occurred most profusely in the forest interior of managed forests, and heat transfer was more limited in the interior of undisturbed forest. Factors besides air temperature that varied across sites and may influence soil temperature are moisture content, wind velocity, understory shade and leaf litter (Bououcs 1916). Soil moisture was variable across sites and over the study period. Lower soil moisture in the managed forest small gaps was an unexpected finding, as the breadth of literature concludes canopy gaps have wetter soils, not just due to greater throughfall, but also as the coinciding belowground gaps in tree roots underlying the canopy gap reduce water demand (Dalsgaard 2007). However, belowground gaps may be short-lived as surrounding tree roots and regenerating vegetation begin to close the gap. Moreover, dense seedling cover may utilize substantial soil moisture. The two gaps studied here, created in a severe thunderstorm three years prior to this study, did have greater throughfall than the forest interiors. The unmanaged forest had greater soil moisture, but this may have been influenced by natural causes such as a vernal pool complex that was observed near Big Pine gap. 
The microclimatic variation across gap and interior in managed and unmanaged northern hardwood stands observed here was insufficient to drive the tree regeneration diversity typically associated with microsite variation (Vodde et al. 2015). Sugar maple seedlings comprised greater than $70 \%$ of seedlings $>30 \mathrm{~cm}$ tall at the monitored sites (see previous chapters). The light compensation point for sugar maple seedlings grown in Big Bay, Michigan was measured to be as low as $5.6 \mu \mathrm{mol} \mathrm{m}^{-2} \mathrm{~s}^{-1}$ PAR (Goldblum et al. 2012). In the unmanaged and managed forest microsites where PAR rarely or never exceeded $200 \mu \mathrm{mol} \mathrm{m}^{-2} \mathrm{~s}^{-1}$, density of sugar maple seedlings ( $>30$ $\mathrm{cm}$ tall) was 3.6 and 2.2 stems per $\mathrm{m}^{2}$, respectively. In the managed forest's wind gap sugar maples seedling density was 3.3 stems per $\mathrm{m}^{2}$, and 3.4 in the unmanaged forest's gap.

This study was limited by a small number of samples, but documents a northern hardwood stands with previous single tree selection having slightly cooler air temperature, higher humidity, and greater spatial variation in soil temperature and moisture than forest without previous harvest. To better understand gap microclimates measuring soil nutrient levels and $\mathrm{pH}$ would have been a fruitful additional component to this study. In addition, more samples would allow a better picture of the range of microclimatic conditions associated with different densities of Acer regeneration and the presence of other species. As cold soil temperatures are a major influence in the germination success of sugar maple, a winter-spring study period would be an interesting

follow up to determine what microsites may be most conducive to support competition by other species, and thus increase stand diversity. Incorporating microclimate into ecologically-based management can increase our understanding of the conditions associated with diverse and productive forest regeneration (Ritter et al. 2005).

\subsection{Implications for ecosystem-based management}

In this study, wind disturbance was observed to deposit large volumes of fresh CWD in wind gaps. In mesic sites CWD is a substrate for the regeneration of eastern hemlock and yellow birch seedlings on decomposing 'nurse logs.' Nurse logs improve survivorship and growth of seedlings and provide a refuge from fungal pathogens of 
seeds (McGee and Birmingham 1997; O’Hanlon-Manners and Kotanen 2004). To improve stand diversity and enhance recruitment of yellow birch, hemlock, and other nurse-log germinates, salvaging wind thrown timber is not advisable.

CWD initially stores carbon, but over time can become a major source of carbon flux to the atmosphere. As such, wind gaps and the associated coarse wood deposits differ substantially from forest interiors in terms of their influence on forest carbon cycling. The microclimates of wind gaps and harvest will influence the rate of log decomposition and has been found to influence respiration by altering temperature and precipitation patterns. Forrester et al. (2012) found CWD surfaces were warmer in small gaps compared to forest interior in an experiment in northern Wisconsin. While moisture was initially higher in CWD in small gaps, two-years after gap creation moisture content was lower in CWD in small gaps compared to closed canopy. Warmer and drier conditions for dead wood may slow decomposition in storm gaps, extending the period of time that carbon is sequestered in logs. Disturbance of the storm gap and coarse wood by salvage activities would accelerate the decomposition process.

\subsection{References}

Abe, S., T. Masaki, and T. Nakashizuka. 1995. Factors influencing sapling composition in canopy gaps of a temperate deciduous forest. Vegetation, 120: 21-32

Bouyouc, C. J.: An investigation of soil temperature and some of the most important factors influencing it. (Mich. Agr. Exp. Sta., Bul. No. 17, 1913; Bul. No. 26, 1916.)

Canham, C.D., A.C Finzi, S.W. Pacala, and D.H Burbank. 1994. Causes and consequences of resource heterogeneity in forests: interspecific variation in light transmission by canopy trees. Can. J. For. Res., 24: 337-349.

Clark, J.B. and G.R. Lister. 1975. Photosynthetic Action Spectra of Trees. Plant Physiology, 55(2): 407-413.

Dalsgaard, L. 2007. Above and below ground gaps - the effects of a small canopy 
opening on throughfall, soil moisture and tree transpiration in Suserup Skov, Denmark. Ecol. Bull. 52: 81-102.

Delisle, G.P., P.M. Woodard, S.J. Titus, A.F. Johnson. 1988. Sample size and variability of fuel weight estimates in natural stands of lodgepole pine. Canadian Journal of Forest Research 18: 649-652.

Duvall MD, Grigal DF (1999) Effects of timber harvesting on coarse woody debris in red pine forests across the Great Lakes states, U.S.A. Can J For Res 29:1926-1934.

Endler, J.A. 1993. The Color of Light in Forests and Its Implications. Ecological Monographs, 63(1): 1-27.

Forrester, J.A., D.J. Mladenoff, S.T. Gower, and J.L. Stoffel. 2011. Interactions of temperature and moisture with respiration from coarse woody debris in experimental forest canopy gaps. Forest Ecology and Management, 265: 124-132.

Hanson, J.J. and Lorimer, C.G. 2007. Forest structure and light regimes following moderate wind storms: implications for multi-cohort management. Ecological Applications, 17: 1325-1340.

McGee, G.G., J.P Birmingham. 1997. Decaying Logs as Germination Sites in Northern Hardwood Forests. Northern Journal of Applied Forestry, 14(4): 178-182.

Momen, B., S.J. Behling, G.B. Lawrence, and J.H. Sullivan. 2015. Photosynthetic and Growth Response of Sugar Maple (Acer saccharum Marsh.) Mature Trees and Seedlings to Calcium, Magnesium, and Nitrogen Additions in the Catskill Mountains, NY, USA. PloS one, 10(8).

O'Hanlon-Manners, D.L. and P.M. Kotanen. 2004. Logs as refuges from fungal pathogens for seeds of eastern hemlock (Tsuga canadensis). Ecology, 85: 284289.

Reed D.D and G.D. Mroz. 1997. Resource assessment in forested landscapes. John Wiley \& Sons, New York, p. 386.

Ritter, E. et al. 2005. Light, temperature and soil moisture regimes following gap formation in a semi-natural beech-dominated forest in Denmark. Forest Ecology and Management 206: 15-33.

Saveyn, A., K. Steppe, N. Ubierna, T.E. Dawson. 2010. Woody tissue photosynthesis and its contribution to trunk growth and bud development in young plants. Plant, Cell and Environment, 33: 1949-1958.

Vatani, L., S. M. Hosseini, M.R. Sarjaz, S.J. Alavi. 2019. Tree species effects on albedo, 
soil carbon and nitrogen stocks in a temperate forest in Iran. Australian Journal of Forest science, 3: 283-310.

Ventre-Lespiaucq, A., N.S. Flanagan, N.H. Ospina-Calderón, J.A. Delgado and A. Escudero. 2018. Midday depression vs. midday peak in diurnal light interception: contrasting patterns at crown and leaf scales in a tropical evergreen tree. Front. Plant Sci., 9.

Vodde, F. et al. 2015. Impact of wind-induced microsites and disturbance severity on tree regeneration patterns: Results from the first post-storm decade. Forest Ecology and Management 348: 174-185

Wittmann C., G. Aschan, and H. Pfanz. 2001. Leaf and twig photosynthesis of young beech (Fagus sylvatica) and aspen (Populus tremula) trees grown under different light regime. Basic and Applied Ecology, 2: 145-154. 


\section{Estimating carbon transfers from decomposing coarse- wood into soil storage in Nantahala, Chippewa, and Angeles National Forests for three tree species}

\subsection{Abstract}

A primary roadblock to applying isotopic tracing to measure carbon transfer from wood to soil is that is that cells of $\mathrm{C}-3$ plants and SOC have very similar isotopic signatures, measured by $\delta^{13} \mathrm{C}$ distribution (-28\%o in leaves, $-26 \%$ in SOC). The Face Wood Decomposition Experiment (FWDE) is using a novel approach to overcome this difficulty, by monitoring the decomposition of logs which have a distinct $\delta^{13} \mathrm{C}$ depleted isotopic distribution ( $\mathrm{irca}-41 \%$ ), having been produced under artificial $\mathrm{CO}_{2}$ augmentation as part of long-running Free-Air Carbon dioxide Enrichment (FACE) experiments. The FWDE experiment compares the relationships between wood decay rate and SOC accumulation for decomposing logs of three tree species, trembling aspen (Populus tremuloides), paper birch (Betula papyrifera), and loblolly pine (Pinus taeda), through the application of isotope tracing, examining soil by depth.

This report examines a subset of results from three FWDE sites to examine how FACE wood decomposition has changed the isotopic signature of soil beneath logs after six years of decomposition. An isotope mixing model is then used to estimate the $\mathrm{C}$ content of soil traceable to the decomposing wood. Finally, the distribution at six years of the log's initial C is determined for three primary pools: 1) assimilated in soil, 2) retained in the log, and 3) returned to the atmosphere through decomposer respiration or otherwise unaccounted for. This study found that after six years of decomposition, depleted ${ }^{13} \mathrm{C}$ wood $\mathrm{C}$ was being imported into the soil at all sites as evidenced by decreasing soil ${ }^{13} \mathrm{C}$. Half or more of the woody $\mathrm{C}$ was retained in the log at year six, and substantial portions were respired to the atmosphere or otherwise unaccounted for. There was measurable assimilation of $\log \mathrm{C}$ within the soil (up to $10 \%$ ). Tree species did not significantly affect $\mathrm{C}$ transfer from coarse wood to soil, but measurable differences in $\mathrm{C}$ storage patterns 
were identified between sites, with the greatest movement of wood $\mathrm{C}$ into soil through six years occurring at a warm, moist site in North Carolina.

\subsection{Introduction}

Coarse woody debris (CWD) in forests provides a myriad of ecological services including structural heterogeneity for wildlife habitat and biodiversity, nutrient and moisture retention, seed substrate, and carbon sequestration (Butts and McComb 2000; Nordén et al. 2004; Kappes et al. 2003; Takahashi et al. 2000; Laiho and Prescott 1999). The total mass of carbon stored in dead woody material is estimated to be over 2,000 teragrams nationally, variable by U.S. forest ecotype (Woodall et al. 2013; Woodall et al. 2008). Globally, it comprises approximately $8 \%$ of total forest carbon (Pan et al. 2011). Retained in some cases at the forest floor for centuries to millennia (Kueppers et al. 2004), CWD functions as long-term carbon storage, however, respiration from decomposition releases $\mathrm{CO}_{2}$ to the atmosphere driving substantial fluctuation of total pool size in any given area. In a mixed northern hardwood stand, CWD decomposed at a rate of $0.09 \mathrm{Mg} \mathrm{C} \mathrm{ha}^{-1}$ year, comprising a flux magnitude exceeding 5\% of total ecosystem storage in CWD (Gough et al. 2007). While studies such as this have improved understanding of carbon flux between CWD and atmosphere, there is a significant knowledge gap in quantifying the carbon flux between CWD and soil C pools, a critical sequestration process in the terrestrial carbon cycle (Heath and Smith 2000).

The discovery of the biochemical pathway by which carbon is assimilated from the atmosphere by plants was a major scientific breakthrough in the 20th century that not only advanced the fields of organic chemistry, biology, and ecology, but also furthered our understanding of the very basis for life on earth. The discovery was made possible by the use of distinct ${ }^{14} \mathrm{C}$ isotopes, which allowed scientists to trace the movement of gaseous $\mathrm{C}$ through plant cells and protein structures into living tissue. Yet, when the living tissue of plants die, major uncertainties persist as to how $\mathrm{C}$ is then cycled through edaphic, atmospheric, and animate carbon pools (Magnússon et al. 2016). In particular, information on the degree to which CWD contributions to soil organic carbon (SOC) are mediated by forest stand composition and structure, decomposer community dynamics 
and abiotic conditions is lacking. Quantifying the proportion of CWD-C to enter longterm soil storage versus short-term pools, and how climatype, tree species, and decomposer community dynamics affect soil $\mathrm{C}$ sequestration is important for refining estimates of forest $\mathrm{C}$ cycling as well as informing sustainable CWD management practices.

The FACE Wood Decomposition Experiment (FWDE) is a collaborative research program with the purpose of studying wood decomposition processes in forests over the long-term ( $>10 \mathrm{yr}$.) and to provide data for improved modeling of wood $\mathrm{C}$ inputs to soil. The FWDE utilized wood from the Department of Energy's Free Air Carbon dioxide Enrichment (FACE) research program (1997 to 2009), which cultivated trees under elevated $\mathrm{CO}_{2}$ to study the effects of carbon enrichment on a variety of physiological and ecological parameters. Wood harvested from the FACE experiments upon their completion has a distinct depleted $\delta^{13} \mathrm{C}$ signature from the use of $\mathrm{CO}_{2}$ derived from fossil fuel to create $\mathrm{aO}_{2}$ enriched atmosphere. This signature facilitates its use in isotopetracer studies. For example wood chips from the FACE study have been used to trace C movement into soils in northern Michigan to assess the importance of decomposer communities and wood placement (above vs. below ground) on rate of $\mathrm{C}$ assimilation in soil (Mosier et al. 2017).

As the climate in which forests grow and foresters operate changes, new management priorities arise. High concentrations of $\mathrm{CO}_{2}$ in the atmosphere prompt the incorporation of forest biomass production and carbon sequestration within global and regional $\mathrm{C}$ management schema. Yet, major uncertainties persist regarding the rate at which woody carbon is ultimately sequestered in forest soils rather than returned to the atmosphere, hindering accurate modeling of the local and global carbon storage and transformations necessary to develop effective management options (Heath and Smith 2000). Confounding this uncertainty in the forest carbon sequestration paradigm is the potential for intensifying climatic disturbances to fundamentally alter abiotic conditions and subsequently species composition and ecosystem function.

The objective of this study is to assess the effect of wood species (Populus tremuloides, Betula papyrifera, and Pinus taeda) and site environmental conditions on 1) 
rate of $\log$ decomposition, 2) proportion of soil C derived from log decomposition, and 3 ) proportion of $\log \mathrm{C}$ assimilated into soil, retained in log, or no longer present. Two factors that influence forest soil $\mathrm{C}$ sequestration are examined here. First, the amount of $\mathrm{C}$ from coarse wood that enters the soil, influenced by rates of decomposition, respiration physical fragmentation and movement of dissolved organic C. Second, of that carbon, how much can be assimilated into the soil over the long term, based on soil characteristics and site topography, saproxylic communities, and climate.

I hypothesize the following:

Hypothesis 1: Log mass loss and rate of wood C movement into soil will be significantly faster at sites with higher mean annual temperature and precipitation

Factors determining the potential and realized $\mathrm{C}$ storage of soils encompass geologic, climatic, biologic, and human management variables (Rabbinge and van Ittersum 1994; Ingram and Fernandes 2001, Kurz et al. 2008; Yoon et al. 2011; Sturtevant et al. 1997). The first differentiating factor across study sites underlying current SOC content is mineralogy; at the broadest scale the nine FWDE study sites can be said to represent five USDA soil orders associated with varying degrees of SOC mass per area. Fine-textured soil structure has been associated with increased SOC as clays bind well with carbon compounds and mineral aggregates provide additional resistance to decay; sandier soils are associated with a higher proportion of labile particulate organic carbon (Huang and Schnitzer 1986).

Temperature and precipitation influence soil $\mathrm{C}$ pool recalcitrance, not only by affecting biotic respiration, but abiotic transport processes of desorption, diffusion, and chemical leaching (Schimel and Schaeffer 2012). Heterotrophic respiration and log decay rates increase with warmer temperatures and increased precipitation (Porgar et al. 2000). Climate cycles can have dynamic effects on soil $\mathrm{C}$ cycling as well. Xiang et al. found after sequential drying-wetting cycles in a California prairie that not only did microbial biomass increase by $500 \%$, but also the major carbon pool to be utilized had an estimated turn-over rate of over 500 years (2008). Warmer and wetter study sites might have a lower long-term accumulation of soil $\mathrm{C}$ assimilation in soil due to respiration and 
leaching. However, in the short-term, wood decay and movement of CWD-C into soil will occur faster. Therefore, I hypothesize that sites with higher mean annual temperature and precipitation will have the greatest portion of wood $\mathrm{C}$ detectable within soil samples collected from FWDE year 6 .

Hypothesis 2: Pinus taeda logs will exhibit the slowest rate of decomposition but greatest proportion of wood C in soil compared to Populus tremuloides or Betula Papyrifera.

Species traits such as nitrogen content and diameter have been observed to more strongly correlate with decay rate than climatic factors of temperature or precipitation, due to stoichiometric and geometric wood traits influencing physical access and bioavailability of nutrients (Hu et al. 2018; Manzoni et al. 2010). Differentiation in the decomposition pathway of wood begins at the cellular level, depending on tree species and the proportions of $\mathrm{C}$ bound by lignin, cellulose, hemicellulose or various metabolites (Rayner and Boddy 1988). Brown-rot fungi, which are more frequently associated with softwoods than hardwoods, have been observed to result in a greater buildup of soil organic matter, attributed in part to the inability of these decomposers to degrade lignin. Conifer biomass also have decay-resistant compounds that result in their litter, including wood, generally being more recalcitrant and acidic than that of hardwoods.

\subsection{Methods}

\subsubsection{Sample design and study site descriptions}

In 2011, logs of loblolly pine (Pinus taeda) (2 $\mathrm{m}$ in length) from the Duke FACE site in North Carolina and of trembling aspen (Populus tremuloides) and paper birch (Betula papyrifera) $(1 \mathrm{~m})$ from the Aspen FACE study in Wisconsin were placed at nine North American forest sites with a range of soil types and climate, creating the Face Wood Decomposition Experiment (FWDE) (Figure 5.1). Logs from trees grown under the elevated $\mathrm{CO}_{2}$ treatment have a depleted isotopic signature $\left(\delta^{13} \mathrm{C}\right.$ circa $\left.-41 \%\right)$ compared to logs from trees grown under the ambient control treatment $\left(\delta^{13} \mathrm{C}\right.$ circa - 
$27 \%$ ). A total of six ${ }^{13} \mathrm{C}$ depleted $\operatorname{logs}$ of each species (18 per site) were placed horizontally on the forest floor in an undisturbed section of forest at each site. After six years of log decomposition $\left(\mathrm{T}_{6}\right)$ soil samples were collected under the logs from 0-2, 2-4, 4-6, and 6-10 $\mathrm{cm}$ soil depths. Control samples $(\mathrm{n}=6)$ were collected from each site at a minimum of $2 \mathrm{~m}$ from any FACE log. This study analyzes soil collected in year 6 (2017) of the FWDE at a subset of 3 National Forest study sites.

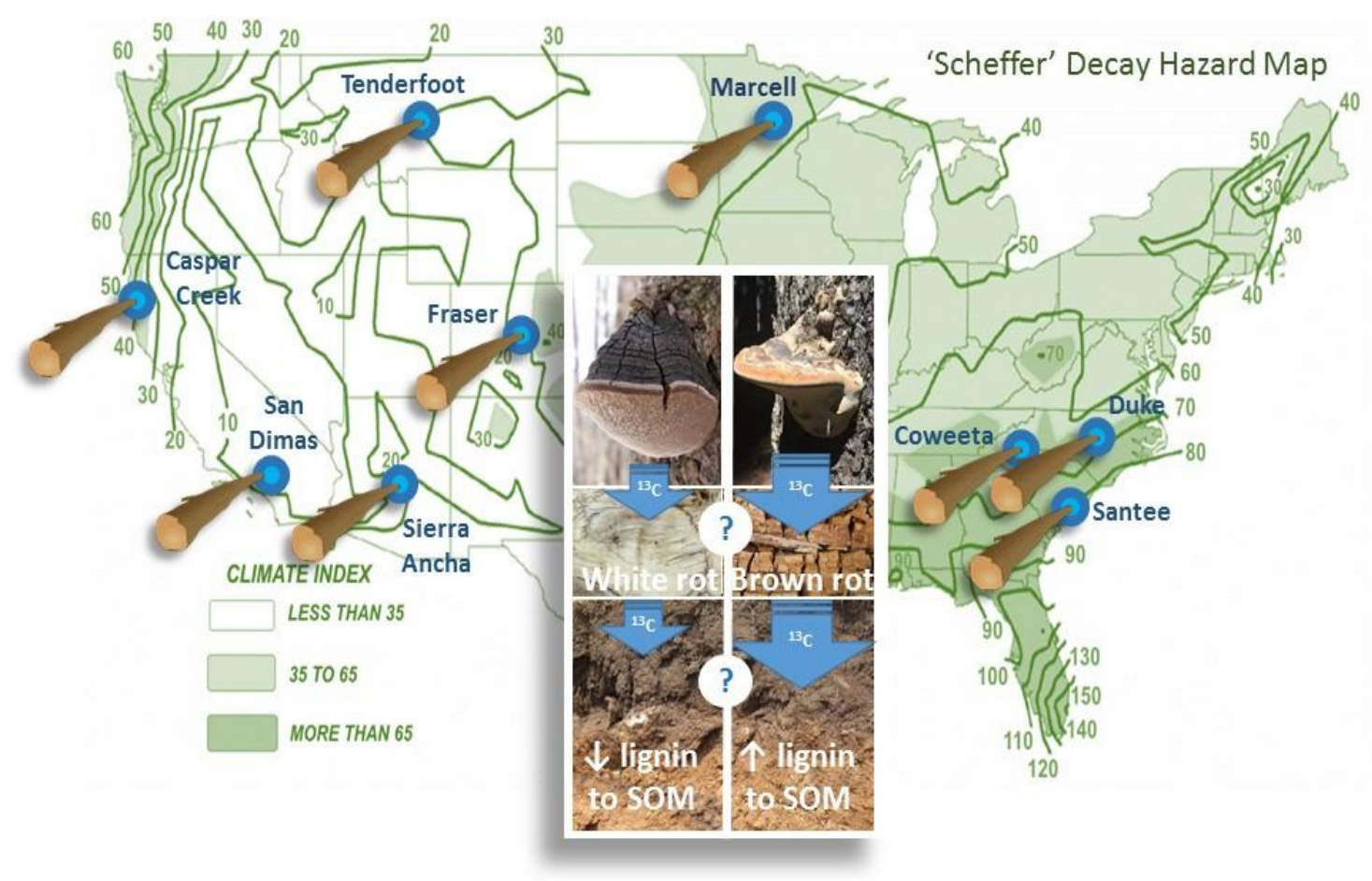

Figure 5.1 Locations of the nine field sites in the FACE Wood Decomposition Experiment

\section{Coweeta Experimental Forest}

'Coweeta' is located in within the Nantahala National Forest in North Carolina (N 35.05549, W 83.47719). Soils are well-drained loams on 30-50\% mountain slopes. At the FWDE site, elevation is $910 \mathrm{~m}$ and cover type is dominated by yellow poplar (Liriodendron tulipifera) and American sweetgum (Liquidambar styraciflua). Climate type is humid temperate with the highest mean annual temperature $\left(12.6^{\circ} \mathrm{C}\right)$ and precipitation (1800-2630 $\mathrm{mm}$ ) among the three sites examined for this report. 


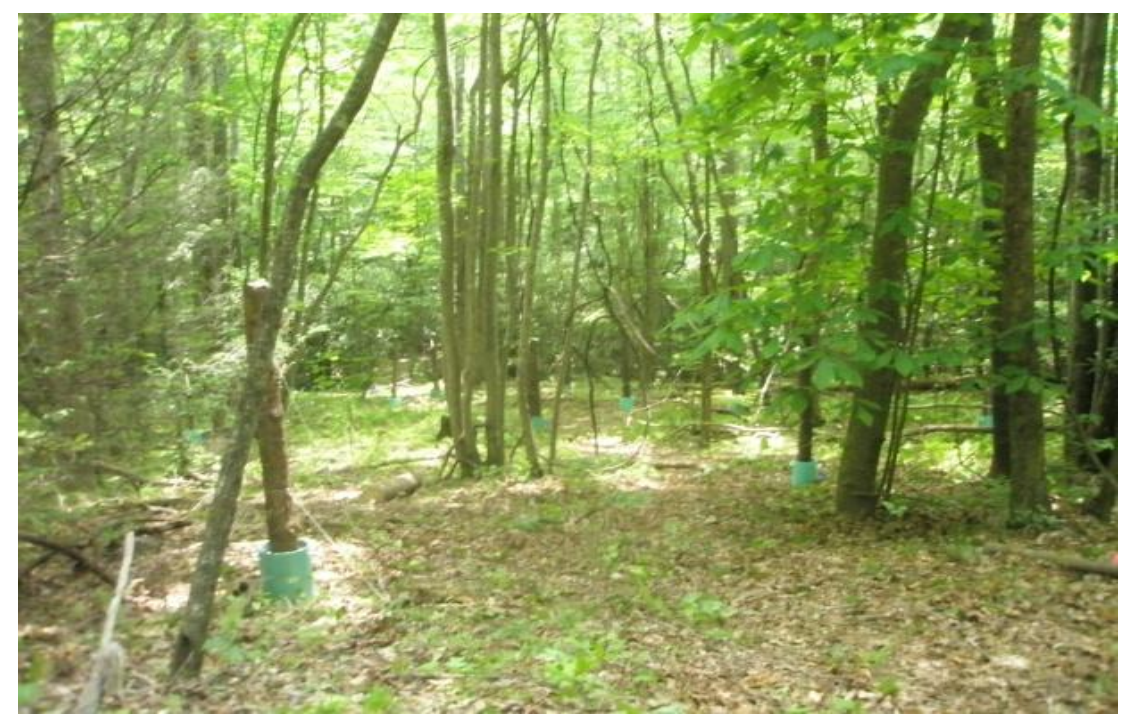

Figure 5.2 'Coweeta' FWDE study site within Nantahala National Forest in N.Carolina

\section{Marcell Experimental Forest}

'Marcell' is located within the Chippewa National Forest in Minnesota (N 47.5056, W 93.4862). The Marcell FWDE site is a red pine (Pinus resinosa) plantation established in 1935. Soils are loamy-sands on $0-8 \%$ slopes and elevation is $430 \mathrm{~m}$. The climate is temperate with cold winters and warm summers. Mean annual temperature is $3.3{ }^{\circ} \mathrm{C}$ and precipitation is $780 \mathrm{~mm}$.

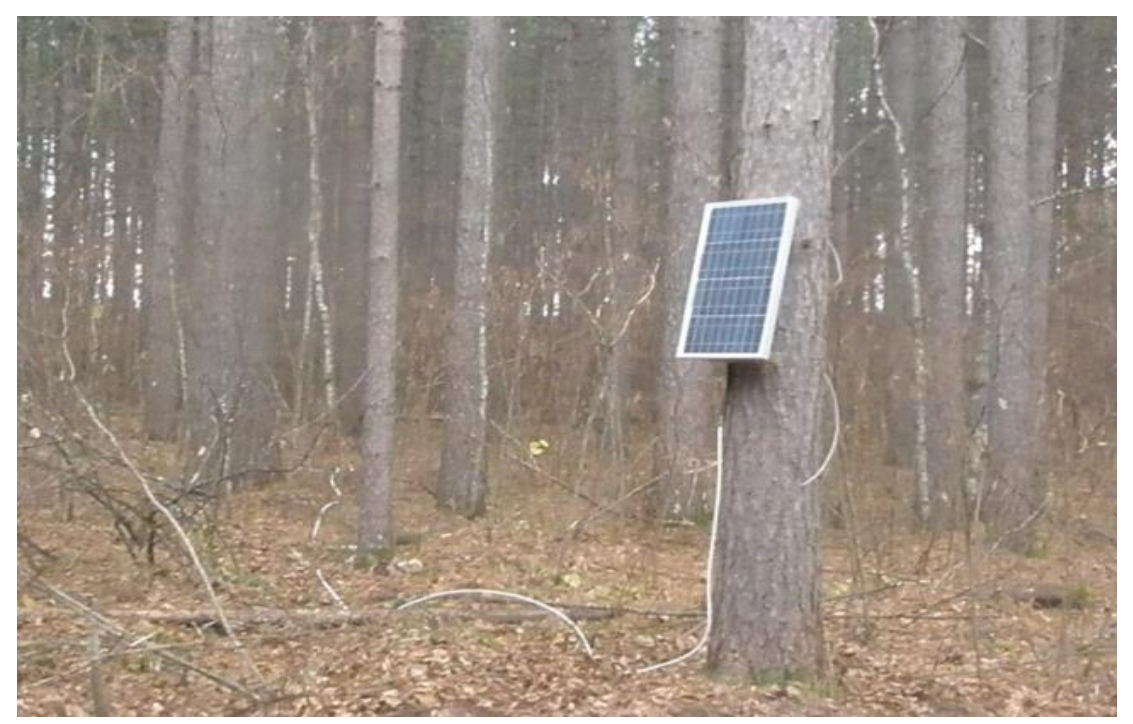

Figure 5.3 'Marcell' FWDE study site within Chippewa National Forest in Minnesota 
San Dimas Experimental Forest

'San Dimas' is located within the Angeles National Forest in Glendora, CA (N 34.18344, W 117.79546). Vegetation at the FWDE site is mixed-chapparal dominated by chamise (Adenostoma fasciculatum), Ceanothus spp., California scrub oak (Quercus dumosa), laurel sumac (Malosma laurina) and manzanita (Arctostaphylos spp.). Soils are shallow and well-drained complexes of the Trigo fine sandy loam series which exists on steep slopes as high as $60-100 \%$. Elevation at the site is $670 \mathrm{~m}$. The climate is hot and dry with $678 \mathrm{~mm}$ precipitation falling mostly in the rainy winter season, and mean annual temperature is $14.4^{\circ} \mathrm{C}$.

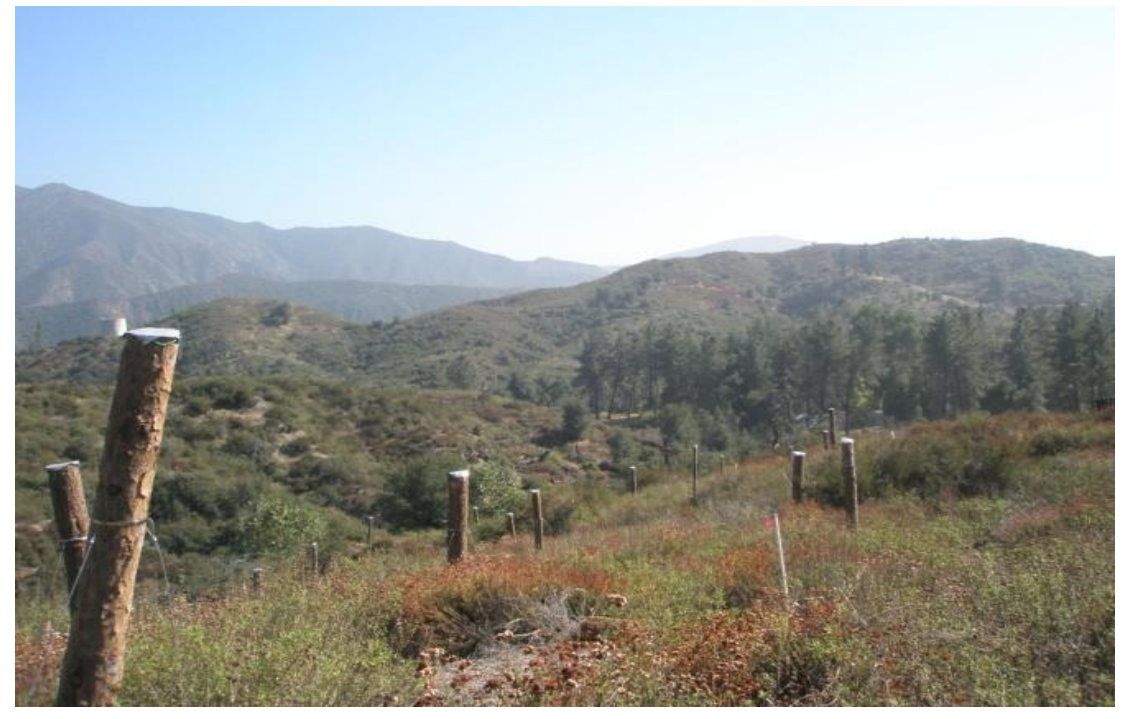

Figure 5.4 'San Dimas' FWDE study site within Angeles National Forest in S. California

\subsubsection{Two-endpoint mixing model estimation of \% soil C derived from log}

To determine $\delta^{13} \mathrm{C}$ and \% $\mathrm{C}$, wood and soil samples were ground and analyzed in a ThermoFinnigan Deltaplus Continuous Flow Stable Isotope Ratio Mass Spectrometer (IRMS; Thermo Fisher Scientific Inc., Waltham, MA, USA) with a Costech Elemental Combustion system 4010 (Costech Analytical Technologies Inc., Valencia, CA, USA). Isotope standards (IAEA, USGS, and NIST certified) were run at the beginning and end of each analytical sequence, with internal standards run every 10 samples. Values were 
reported on the Vienna PeeDee Belemnite (VPDB) scale for $\delta^{13} \mathrm{C}$. The precision of the certified isotopic standards is typically 0.2-0.5\%o. (Mosier et al. 2017). A mixing model (Figure 5.5) was applied to estimate the \% soil C sourced from the decomposing log above. Source 1 , the original $\delta^{13} \mathrm{C}$ of wood, was measured directly from individual logs, whereas source 2 , the $\delta^{13} \mathrm{C}$ of control soil, was an average from six reference soil samples per site from each unique soil depth.

A two-endpoint mixing model estimated the relative contribution of CWD to soil $\mathrm{C}$ at each sample depth by use of the equation:

$$
f_{1}=\left(\delta_{\text {SAMPLE }}-\delta_{\text {SOURCE2 }}\right) /\left(\delta_{\text {SOURCE1 }}-\delta_{\text {SOURCE2 }}\right)
$$

where $f_{1}=$ fraction of soil $\mathrm{C}$ from decomposing log at given depth

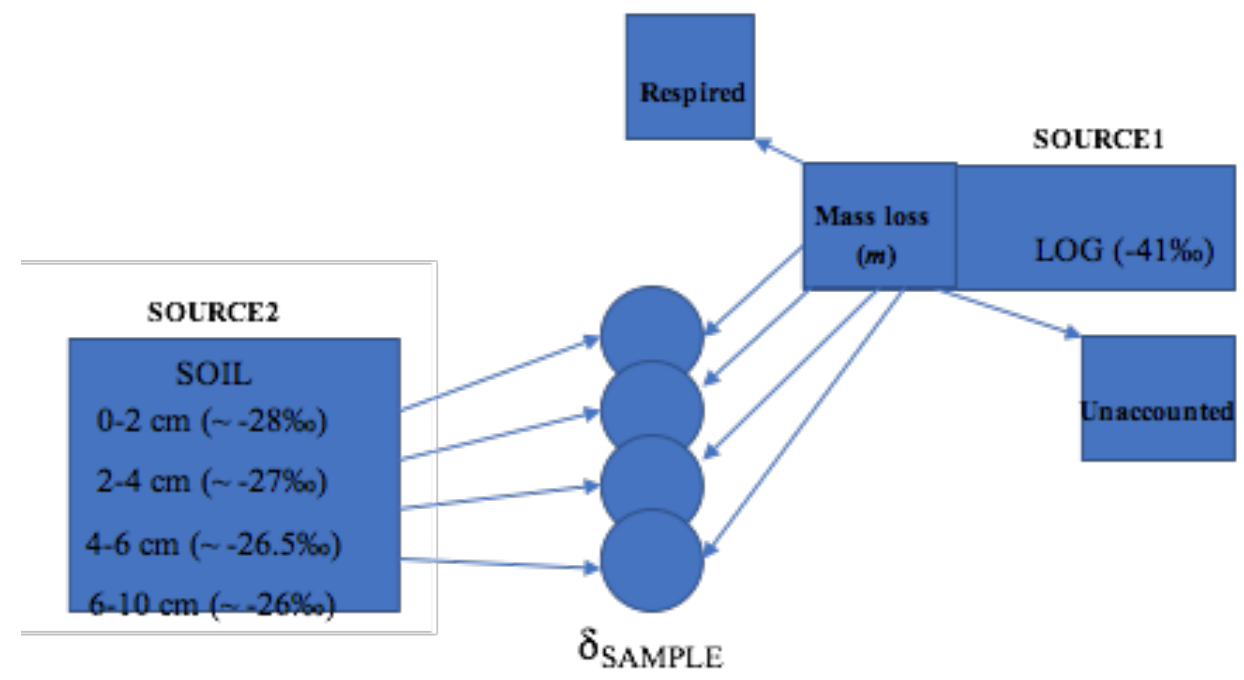

Figure 5.5. Visual schematic of hypothetical two-end mixing model inputs to determine proportion of soil carbon from decomposing logs

The mixing model was used to calculate the proportion of soil carbon from decomposing logs at each soil depth. To calculate the total proportion of soil $\mathrm{C}$ in the top $10 \mathrm{~cm}$ derived from the $\log$ above, $f_{1}$ values were multiplied by the $\mathrm{C}$ concentration of each depth, summed, and then divided by the sum of $\mathrm{C}$ concentrations across the depths. The 6-10 cm increment given twice the weighting of the three $2 \mathrm{~cm}$ depth increments in the calculation. 


\subsubsection{Estimation of log carbon transferred to soil, retained in log, and unaccounted}

The proportion of the log's carbon transferred to the soil was estimated by first calculating the soil sample area beneath the log by taking the two-dimensional footprint of the $\log$ and multiplying it by each soil depth $(a * d)$. This soil volume was multiplied by the fraction of $\mathrm{C}$ found in the soil derived from the $\log (f 1)$, soil density $\left(\mathrm{g} \mathrm{cm}^{-3}\right)$, and total soil \% $\mathrm{C}$ providing, an estimate at $\mathrm{T}_{6}$ of soil $\mathrm{C}$ mass from the $\log$ in $\mathrm{g}$. This ratio is then divided by the total $\mathrm{g}$ of $\mathrm{C}$ in the $\log$ at $\mathrm{T}_{0}$ giving an estimate of the percent of $\log$ carbon found in the soil beneath it. Total $\% \log \mathrm{C}$ transferred to the top $10 \mathrm{~cm}$ of soil is the sum of $\% \log \mathrm{C}$ transferred to each soil depth. The calculation used the following equations:

a. $\% \log$ carbon in soil beneath $=$ ' $\mathrm{S}_{6}$ '

$$
\begin{aligned}
& \qquad \mathrm{S}_{6}=\left(f_{1}^{*} \mathrm{a}^{*} \mathrm{~d}{ }^{*} \mathrm{~b}{ }^{*} \text { soil } \mathrm{C}\right) /\left(\mathrm{M}_{0}{ }^{*} \mathrm{C}_{0}\right) \times 100 \% \\
& \mathrm{a}=\text { rectangular footprint of } \log =\log \text { length } * \text { (top diameter }+ \text { bottom diameter }) / \\
& \mathrm{d}=\text { soil depth in cm for the soil increment }(2 \text { or } 4) \\
& \mathrm{b}=\text { soil fine fraction density }\left(\mathrm{g} \mathrm{cm}^{-3}\right) \\
& \text { soil C }=\text { soil } \mathrm{C} \% / 100 \\
& \mathrm{M}_{0}=\mathrm{T}_{0} \log \text { mass }(\mathrm{g}) \\
& \mathrm{C}_{0}=\left(\mathrm{T}_{0} \log \mathrm{C} \%\right) / 100
\end{aligned}
$$

Log mass was measured at $\mathrm{T}_{0}$ and $\mathrm{T}_{6}$ by weighing whole logs in-situ as well as removing two discs that were returned to the lab where disc moist volume and moist and dry mass were determined. This enabled the determination of wood density for each log (D, $\mathrm{g}$ dry mass $\mathrm{cm}^{-3}$ ), to be used in adjusting the moist log mass to an oven-dry weight. Percent wood mass loss for each $\log$ from $T_{0}$ to $T_{6}$ was estimated to be the same as the change in wood density over the time period. The proportion of the log's initial C 
remaining at $\mathrm{T}_{6}$ was assumed to be equal to the proportion of log's mass retained and was calculated by the following equation:

b. $\% \mathrm{~T}_{0} \log$ carbon remaining in log at $\mathrm{T}_{6}={ }^{\prime} \mathrm{L}_{6}$ '

$$
L_{6}=\left(1-D_{6} / D_{0}\right) \times 100 \%
$$

where $\mathrm{D}_{0}$ and $\mathrm{D}_{6}$ are wood density at $\mathrm{T}_{0}$ and $\mathrm{T}_{6}$, respectively.

The proportion of the log's carbon respired during decomposition or otherwise unaccounted for was assumed to be the portion not found in soil or retained in the log, by the following equation:

c. $\%$ log carbon unaccounted = ' $\mathrm{U}_{6}$ '

$$
\mathrm{U}_{6}=100-\mathrm{S}_{6}-\mathrm{L}_{6}
$$

\subsubsection{Statistical Analysis}

Isotopic $\delta^{13} \mathrm{C}$ was compared between control soils and those beneath FACE logs in an ANOVA with each soil depth as repeated measures to confirm that statistically significant detectable of wood C were moving into soil. Two-way ANOVA was implemented to test for differences in total soil $\mathrm{C}$ to $10 \mathrm{~cm}$ derived from the $\log$ with post-hoc Tukey to evaluate the influence of tree species and site. The relationship between wood mass loss and movement of wood $\mathrm{C}$ into soil was analyzed by applying a general linear mixed-effects regression model with data assessed for normality by Shapiro-Wilks and Kolmogorov-Smirnov statistics. ANCOVA analysis was performed to assess the influence of mass loss as a covariate on soil $\mathrm{C}$ derived from the log, and the distribution of $\log \mathrm{C}$ in soil, with site and species as co-factors. 


\subsection{Results}

\subsubsection{Variation in Soil $\delta^{13}$ C samples by depth and treatment}

A natural pattern of increasing $\delta^{13} \mathrm{C}$ with soil depth was found in control samples at all sites (Figure 5.6). At Coweeta, the soil under decomposing FACE logs had significantly lower $\delta^{13} \mathrm{C}(\mathrm{M}=-27.8 \pm 0.13 \%$, mean \pm standard deviation $)$ than control soil $(-27.2 \pm 0.8 \%$ o). A repeated measures ANOVA with Greenhouse-Geisser adjustment indicated that mean $\delta^{13} \mathrm{C}$ differed significantly by soil depth and that there was a significant effect of FACE wood decomposition $(p=0.027)$. At Marcell, there was no significant effect of FACE wood decomposition on soil $\delta^{13} \mathrm{C}$, but the depletion by soil depth was significant $(\mathrm{p}<0.001)$. A post-hoc t-test with Bonferonni adjustment indicated that at 6-10 cm soil depth, soil under FACE logs was significantly more $\delta^{13} \mathrm{C}$ depleted ($26.5 \pm 0.38 \%$ o $)$ compared to the control $(-26.0 \pm 0.13 \%)(p=0.001)$. At San Dimas, soil $\delta^{13} \mathrm{C}$ was significantly lower under FACE logs than in control areas $(\mathrm{p}<0.001)$ and varied by soil depth $(\mathrm{p}<0.001)$, but there was no interactive effect of treatment and soil.

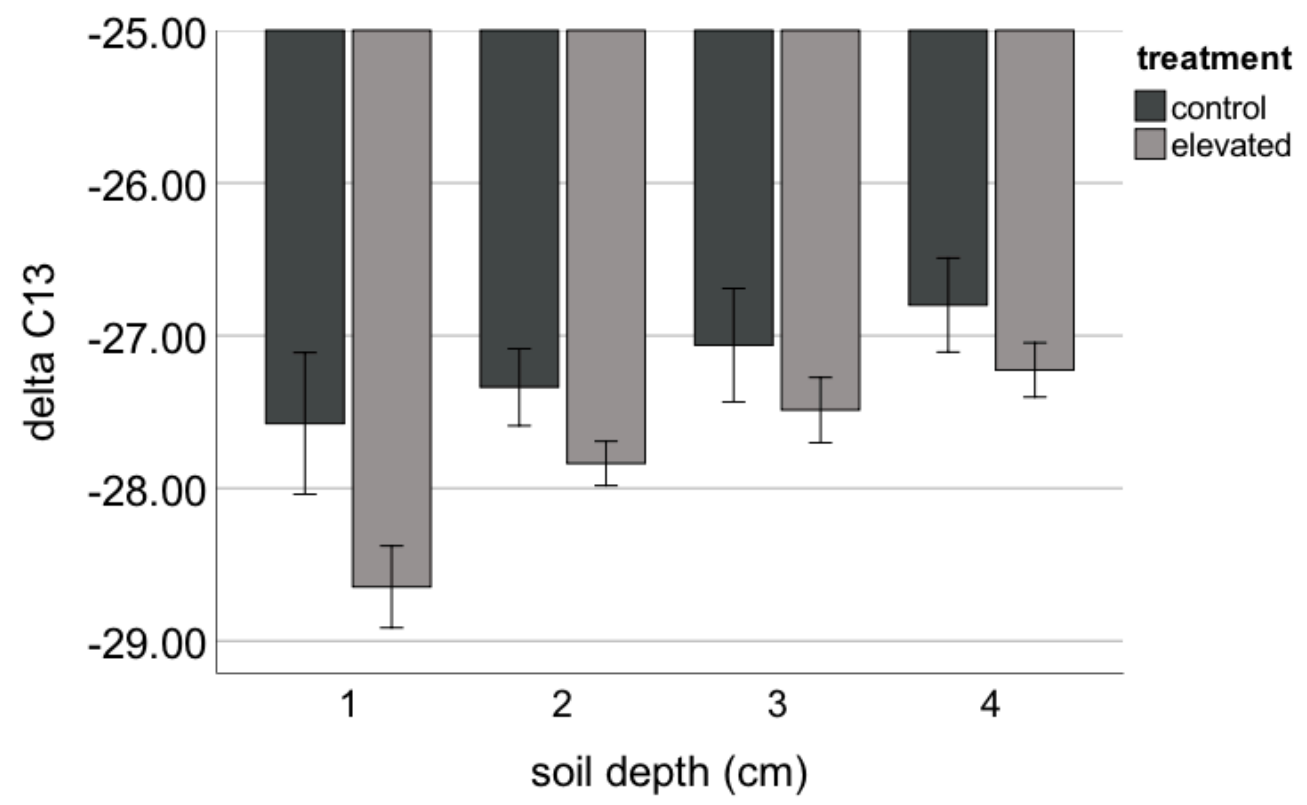

(A). Coweeta 


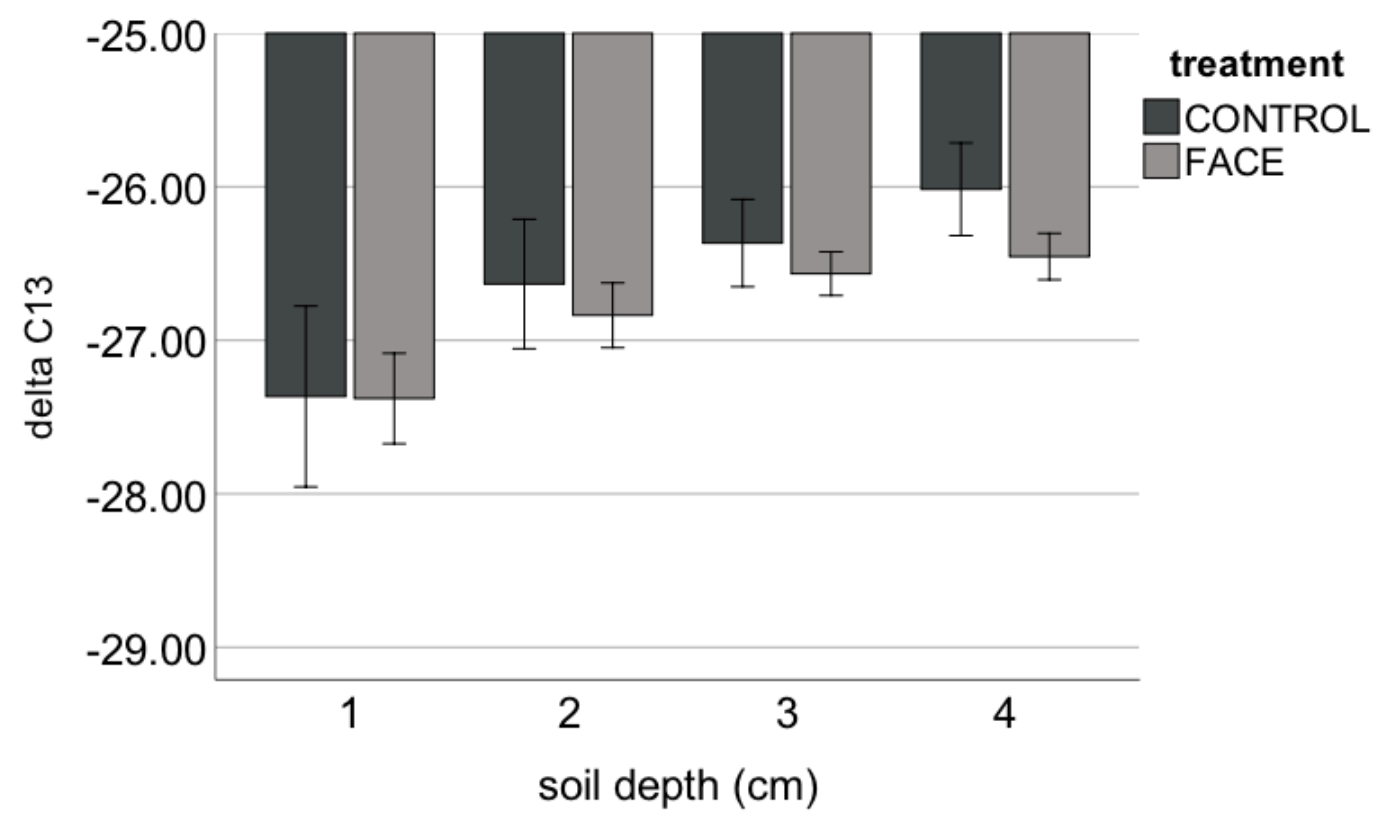

(B). Marcell

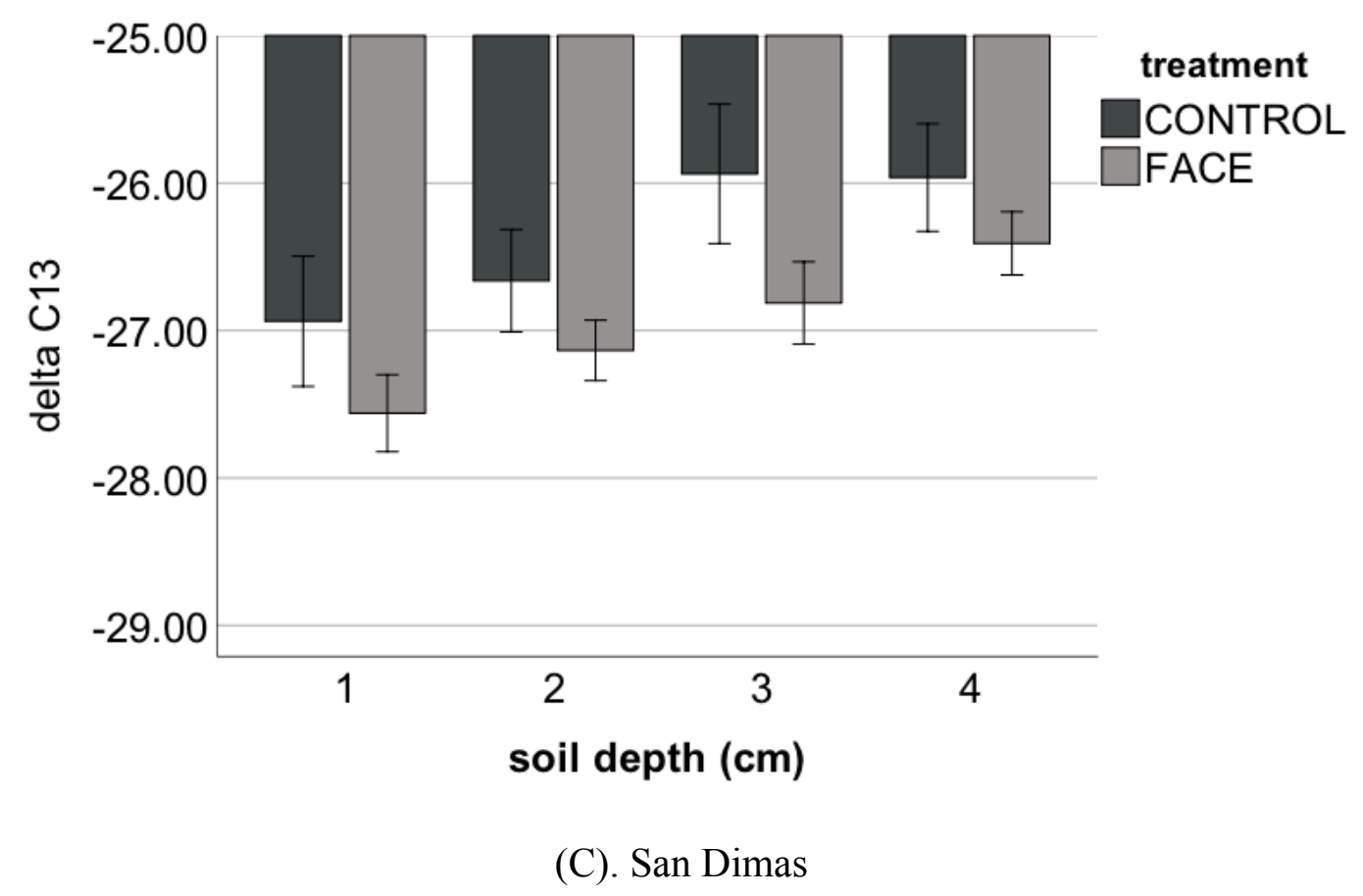

Figure 5.6. Isotopic signatures $\left(\delta^{13} \mathrm{C}\right)$ of soil sampled below control and FACE logs 
Table 5.1 Repeated measures ANOVA results comparing $\delta^{13} \mathrm{C}$ by soil depth and treatment (elevated vs. control)

\begin{tabular}{ccccccc}
$\begin{array}{c}\text { Type III } \\
\text { sum of } \\
\text { squares }\end{array}$ & df & Mean & & & \multicolumn{2}{c}{ Partial } \\
Eta \\
Square & F & Sig. & Squared \\
\hline
\end{tabular}

\section{COWEETA}

$$
\text { Tests of Within-Subjects Effects }{ }^{\dagger}
$$

\begin{tabular}{lcccccc}
$\begin{array}{l}\text { soil depth (d) } \\
\text { depth } \boldsymbol{x}\end{array}$ & 16.044 & 1.884 & 8.516 & 36.248 & $\mathbf{0 . 0 0 0}$ & 0.547 \\
treatment & 1.757 & 1.884 & 0.933 & 3.969 & $\mathbf{0 . 0 2 7}$ & 0.117 \\
Error(soil) & 13.278 & 56.519 & 0.235 & & & \\
& & \multicolumn{2}{c}{ Between-subject Effects } & & \\
Intercept & 72580.751 & 1 & 72580.751 & 134399.293 & $\mathbf{0 . 0 0 0}$ & 1 \\
treatment & 8.791 & 1 & 8.791 & 16.278 & $\mathbf{0 . 0 0 0}$ & 0.352 \\
Error & 16.201 & 30 & 0.54 & & & \\
\hline
\end{tabular}

MARCELL

Tests of Within-Subjects Effects ${ }^{\dagger}$

\begin{tabular}{lcccccc}
$\begin{array}{l}\text { soil depth } \\
\text { depth } \mathrm{x}\end{array}$ & 13.907 & 2.111 & 6.587 & 38.117 & $\mathbf{0 . 0 0 0}$ & 0.577 \\
treatment & 0.436 & 2.111 & 0.207 & 1.195 & 0.312 & 0.041 \\
Error(soil) & 10.216 & 59.115 & 0.173 & & & \\
\multicolumn{7}{c}{ Between-subject Effects } \\
Intercept & 54760.633 & 1 & 54760.633 & 86719.363 & $\mathbf{0 . 0 0 0}$ & 1 \\
treatment & 0.876 & 1 & 0.876 & 1.386 & 0.249 & 0.047 \\
Error & 17.681 & 28 & 0.631 & & & \\
\hline
\end{tabular}

SAN DIMAS

\begin{tabular}{|c|c|c|c|c|c|c|}
\hline \multicolumn{7}{|c|}{ Tests of Within-Subjects Effects } \\
\hline $\begin{array}{l}\text { soil depth } \\
\text { depth } \mathrm{x}\end{array}$ & 16.834 & 3 & 5.611 & 21.598 & 0.000 & 0.427 \\
\hline treatment & 0.691 & 3 & 0.23 & 0.886 & 0.452 & 0.03 \\
\hline Error(soil) & 22.603 & 87 & 0.26 & & & \\
\hline \multicolumn{7}{|c|}{ Between-subject Effects } \\
\hline Intercept & 67585.846 & 1 & 67585.846 & 133484.622 & $\mathbf{0 . 0 0 0}$ & 1 \\
\hline treatment & 8.671 & 1 & 8.671 & 17.126 & 0.000 & 0.371 \\
\hline
\end{tabular}




\subsubsection{Log decay and \% soil C derived from log by site and species}

There was a significant effect of site (Two-way ANOVA, $\mathrm{p}<0.00$ ), but not species on rate of log decomposition (Figure 5.7). Post-hoc analyses indicated that Coweeta and Marcell were not different in terms of rate of mass loss, but logs at San Dimas lost mass significantly slower.

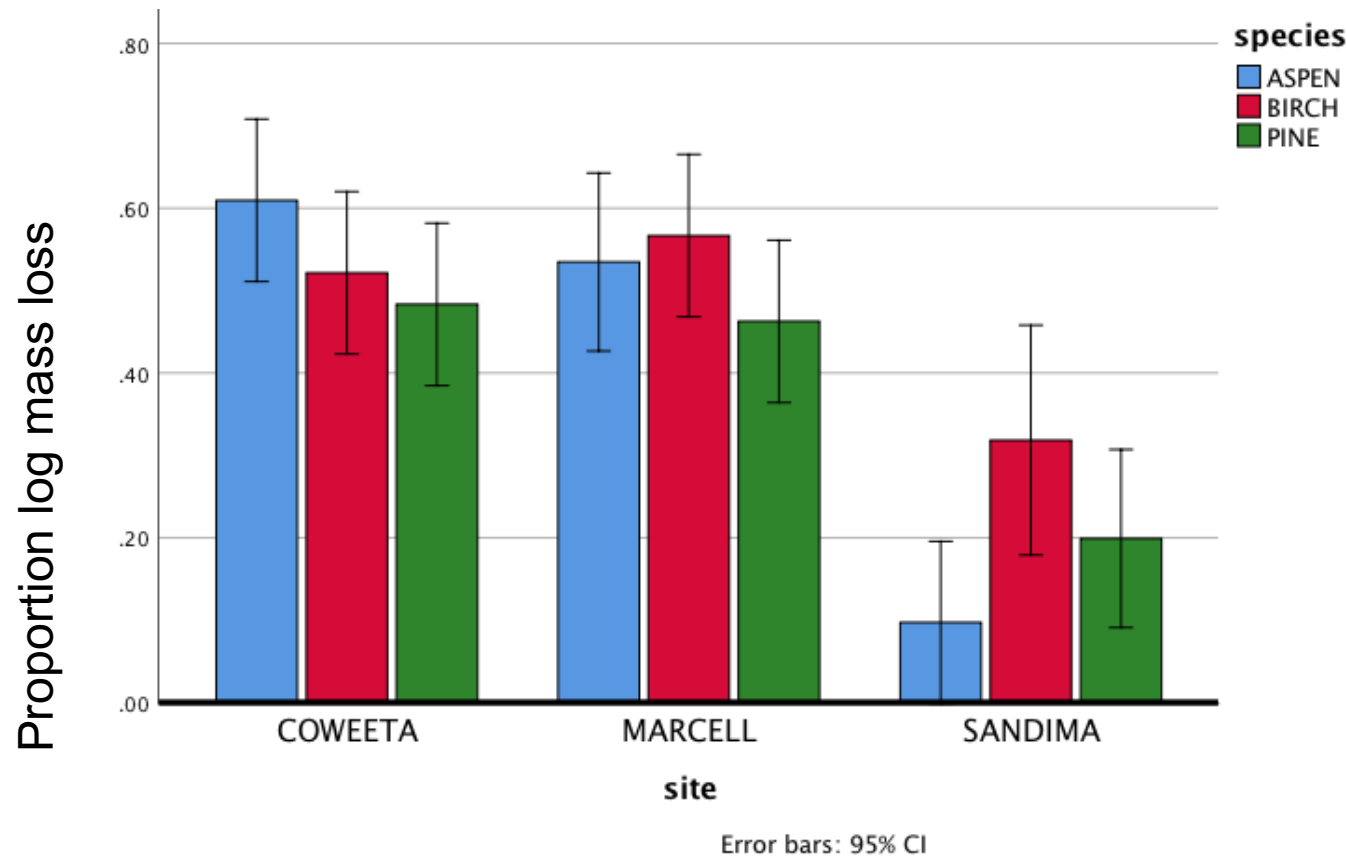

Figure 5.7 Proportion of mass loss from log decomposition by site and species at year 6

The mixing model was applied to determine what percent of soil $\mathrm{C}$ was estimated to have come from the decomposing log above. The highest contribution of log carbon into the soil was found at Coweeta in the uppermost soil, $0-2 \mathrm{~cm}$ depth, beneath logs of Populus tremuloides $(10.5 \pm 4.4 \%)$ (Figure 5.8). At Coweeta, movement of $\mathrm{C}$ from decomposing Betula papyrifera and Pines taeda logs also decreased soil $\delta^{13} \mathrm{C}$ in the upper 0-2 cm. At Marcell, depleted $\delta^{13} \mathrm{C}$ was more apparent in deeper soil layers, and the trend was most pronounced under logs of Pinus taeda. Differences were significant by site (two-way ANOVA, $\mathrm{p}=0.007$ ). Post-hoc analysis found that Marcell was statistically unique from San Dimas and Coweeta. Differences between species were not, however, significant. 


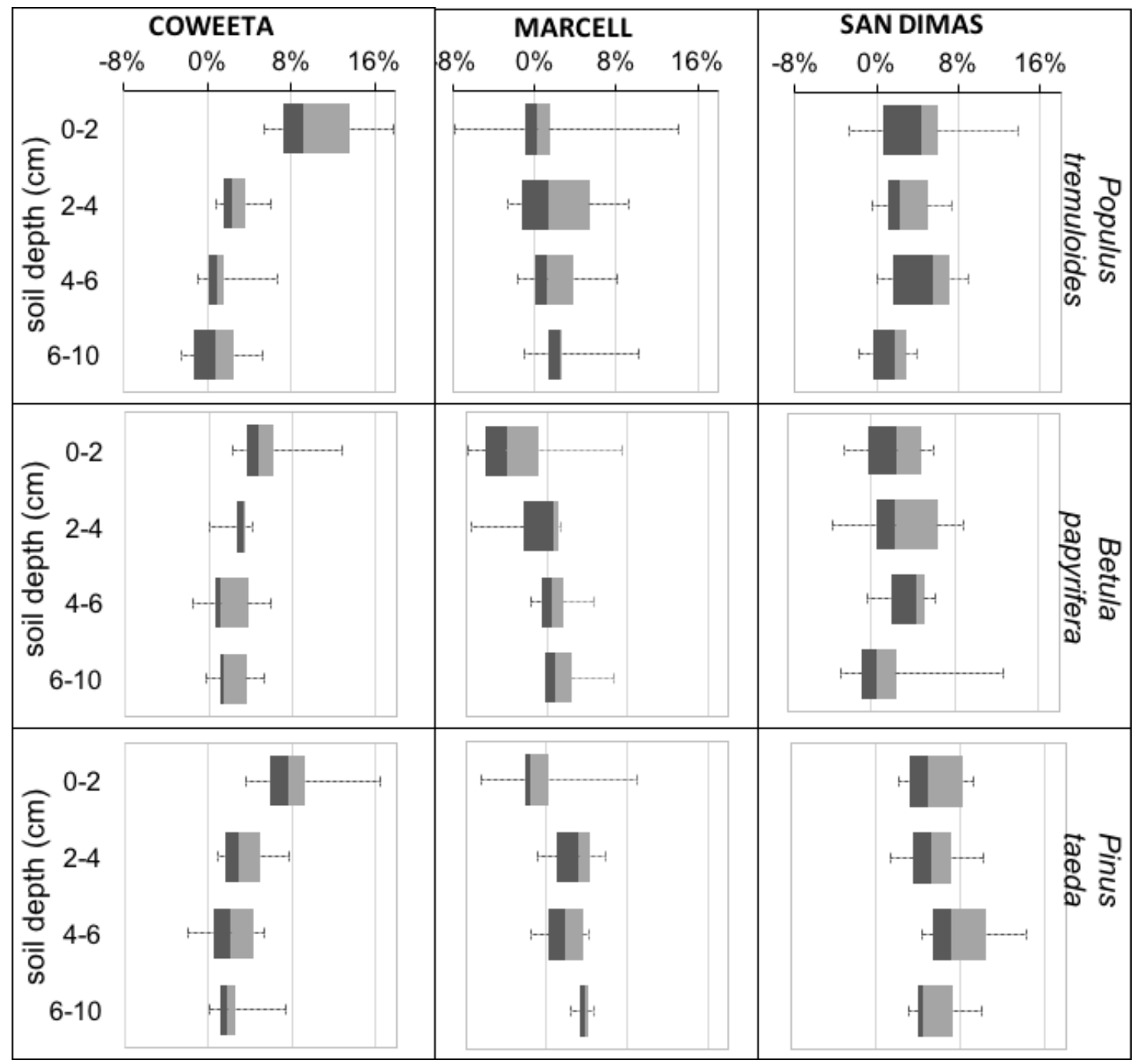

Figure 5.8 Proportion of soil carbon derived from decomposing logs at soil depths to 10 $\mathrm{cm}$ 


\subsubsection{Proportions of log carbon transferred to soil, retained in log, and unaccounted for by species and site}

Across all sites and species, faster log decomposition correlated weakly to a smaller proportion of soil $\mathrm{C}$ estimated to be derived from the $\log (\mathrm{F}(1,47)=5.29, \mathrm{p}=$ $0.03, \mathrm{R}^{2}=.32$ ) (Figure 5.9A). An ANCOVA analysis found site to be a significant cofactor, but not species. There was no correlation between rate of log decomposition and the proportion of $\log \mathrm{C}$ transferred to the soil (Figure 5.9B). Moreover, site differences were more evident than species differences.

The proportion of carbon estimated to be assimilated in the soil varied significantly by site $(\mathrm{p}=0.005)$, but there was no significant difference between species in two-way ANOVA. Post-hoc analysis indicated Coweeta had significantly more $\log \mathrm{C}$ assimilated in soil, and there was no statistical difference $\log \mathrm{C}$ in soil between Marcell and San Dimas (Figure 5.10). Carbon retained in log and soil was greatest at San Dimas, driven by slower rate of decomposition of the logs.

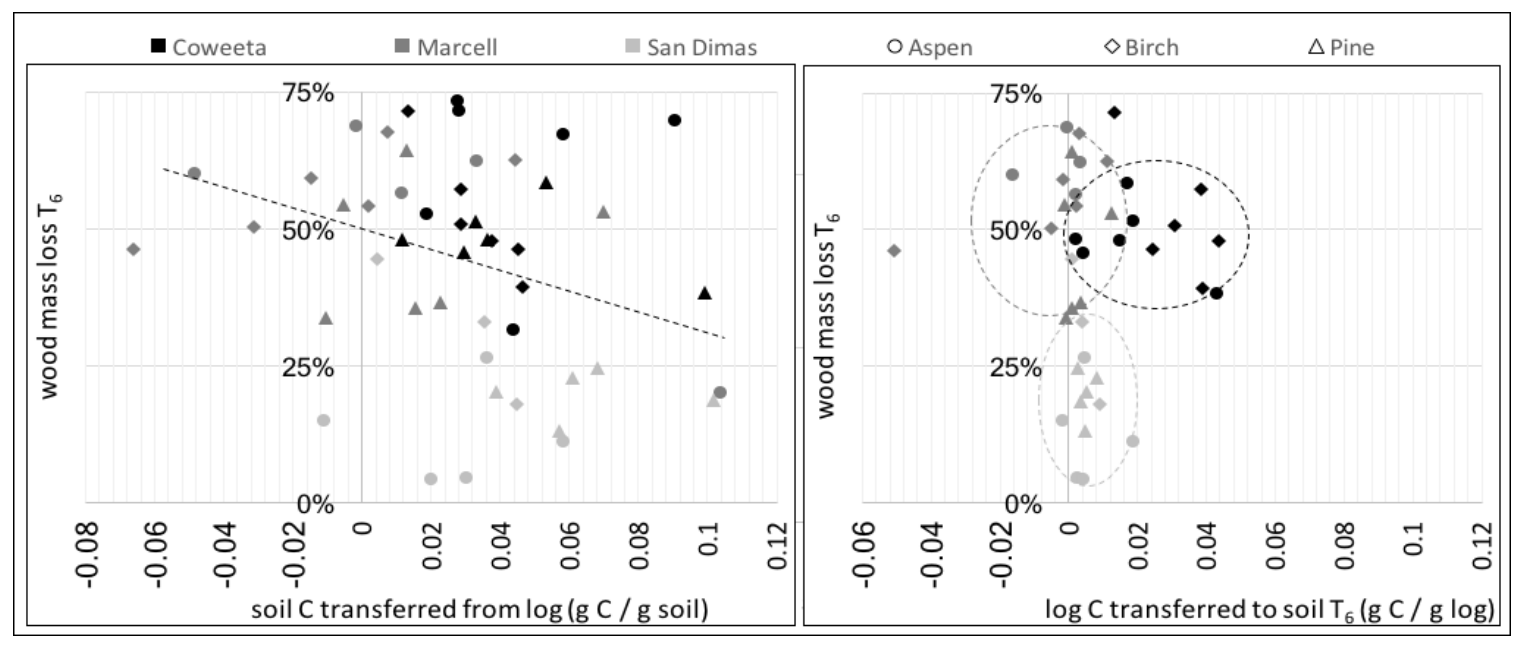

Figure 5.9. Estimated proportions gram per gram of soil $\mathrm{C}$ from decomposing $\log (\mathrm{A})$ and $\log \mathrm{C}$ in soil (B) versus \% wood mass loss at year 6 


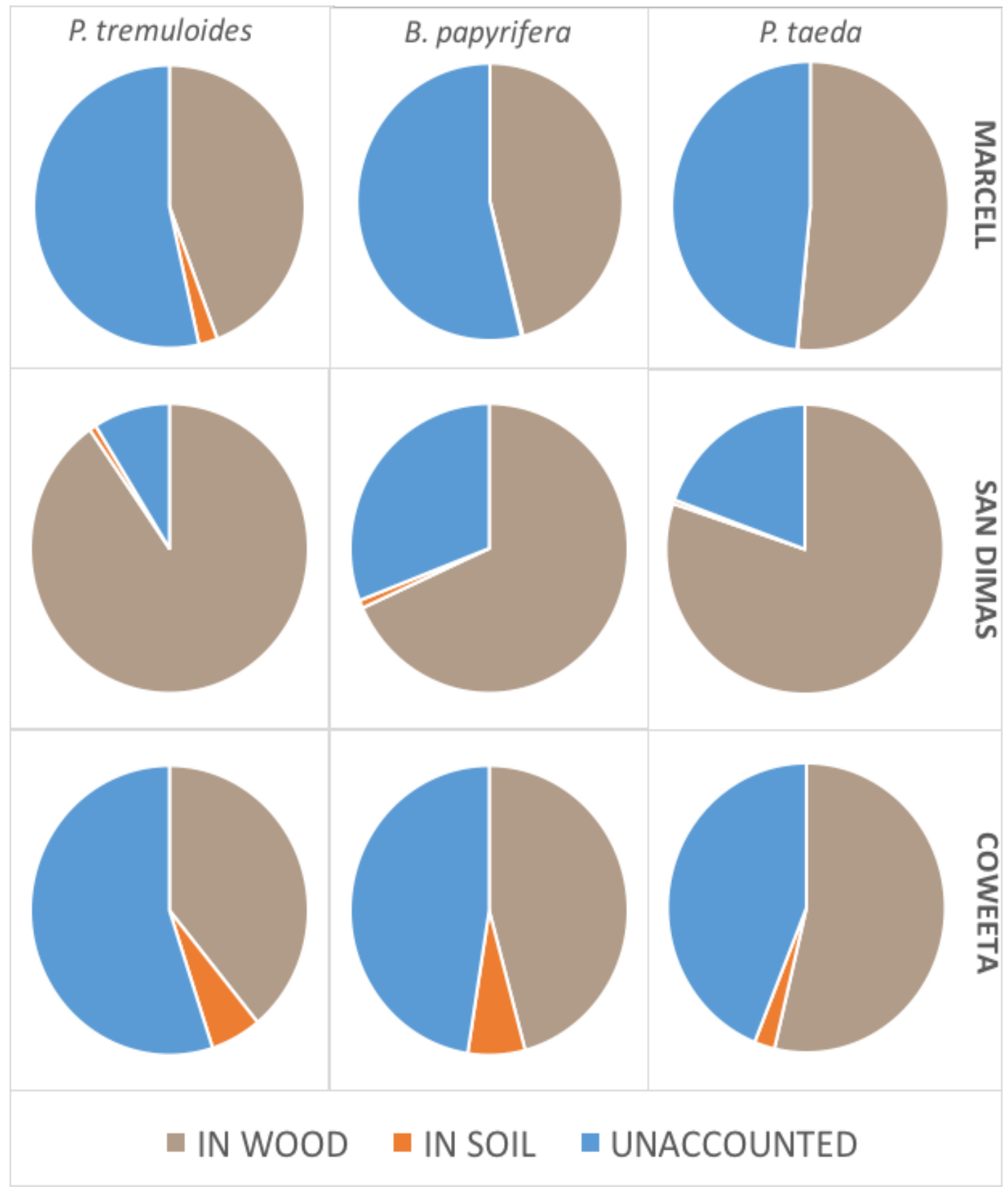

Figure 5.10 Estimated proportions of carbon retained in logs and soil, and unaccounted fate 


\subsection{Discussion}

Site differences in coarse wood C transfers to soil were far more apparent than differences among species. In the Nantahala National Forest site (Coweeta) log decomposition proceeded quickly, with logs losing $54 \%$ mass in the first six years. At this site, approximately $4 \%$ of soil $\mathrm{C}$ in the top $10 \mathrm{~cm}$ had been transferred from the decomposing log. A similar rate of decomposition, $52 \%$ mass loss, was observed at the pine plantation within the Chippewa National Forest (Marcell). However, less than $1 \%$ of surface soil carbon was estimated to have been transferred from the decomposing log. Approximately half of the coarse wood $\mathrm{C}$ at these two sites was unaccounted for by year six. Respiration of wood $\mathrm{C}$ by decomposing organisms likely accounts for substantial portions of the 'missing' C, but some of this 'missing' wood C likely migrated within the soil to deeper layers or horizontally away from the sample area beneath the log via leaching of dissolved organic carbon or being moved by fungal hyphae or soil arthropods. In this case, estimates of the total amount of wood C transferred to soil based on a $10 \mathrm{~cm}$ sample area beneath the log are conservative.

Logs placed within the Angeles National Forest (San Dimas) decomposed more slowly than at other sites (18\% at year 6) and had the smaller portion of $\mathrm{C}$ unaccounted for. Low concentrations of $\mathrm{C}$ in the soil at San Dimas result in a high percent of soil C estimated to be derived from the log, which causeed the negative correlation between rate of decomposition and soil C assimilation. However, at San Dimas relatively little $\log \mathrm{C}$ was transferred to the soil after six years of decomposition, and the majority of wood C was retained in the logs. This has significant implications for the importance of conserving the coarse woody debris carbon pool in the Angeles National Forests. Furthermore, future studies to determine the driving factors behind these unique patterns of coarse wood to soil carbon transfers will not only help improve carbon cycle modeling, but also provide insight into where coarse wood conservation for carbon sequestration would be most effective.

Negative figures were frequently calculated for $\%$ soil C content from log decomposition at Marcell. This may be due, in part, to high spatial variability in $\delta^{13} \mathrm{C}$ of the reference soils. Taking a larger number of reference samples at this site may lead to 
more accurate estimates of carbon transfer. High variability in the proportion of log carbon entering the soil surface $(0-2 \mathrm{~cm})$ indicates a spatially heterogeneous pattern of $\log$ carbon assimilation. This could be due to subtle changes in soil properties, decomposer community distributions, microtopography and microclimate, or chance wildlife interactions. If the discrepancy was caused by processes related to log decomposition, we would expect fewer negative numbers in the soil samples furthest away from the log, and should be further investigated.

The hypothesis that log mass loss and short-term rate of wood $C$ movement into soil will be significantly faster at sites with higher mean annual temperature and precipitation was supported by this research. However, an important caveat of this research is the short time scale relative to the long-term process of coarse wood decomposition. Coarse wood carbon transferred to the soil at year 6 may not be permanent as it is subject to further processing and loss. Future research should examine the proportions of this carbon existing soil fractions of differing stability. In cold climates for example, stand productivity correlated with lower SOC and shallower organic horizons, but a greater proportion of SOC was found in mineral-associated fractions, likely a result of more intensive microbial processing in more productive locations and suggesting a longer turnover time (Kane et al. 2005). The distinct mineral, climate, and primary productivity profiles of the focal sites will entail distinct below-ground communities forged of fungal, microbial, and animal associations unique to each site.

The long-term carbon storage potential of soils is largely a factor of soil clay content. Carbon that becomes mineral associated or occluded in soil structures is highly resistant to further decomposition and can have a turnover rate of up to several thousand years (Parton et al. 1987). The physical occlusion of $\mathrm{C}$ in aggregates in mineral soils inhibits microbial access and thus is likely a critical, abiotic rate-limiting step in carbon decomposition (Schimel and Schaeffer 2012). In contrast, free light soil fractions are more vulnerable to disturbance and further decompositon (Houghton 2003). While soil composition exerts strong influence on $\mathrm{C}$ holding capacity, the persistence of SOM and the $\mathrm{C}$ sequestration of capacity of soil is increasingly attributed to ecological processes (Schmidt et al. 2011). The influence of saproxylic community dynamics is now posited to 
be a major controlling force behind SOC cycling. While respiration of this community is the greatest source of $\mathrm{C}$ to the atmosphere, there is growing evidence that biologicallymoderated decay pathways can result in greater long-term stabilization of $\mathrm{C}$ in soils due to smaller particle sizes and lipid-rich necromass being conducive to stable bonding with soil particles (Malik et al. 2016; Lehmann and Kleber 2015).

The hypothesis that Pinus taeda logs will exhibit the slowest rate of decomposition, but greatest proportion of wood C in soil compared to Populus tremuloides or Betula Papyrifera was partially supported by this research. Pinus taeda was found to have a slower rate of decomposition than Populus tremuloides or Betula Papyrifera, but log to soil transfers of carbon were not measurably different across species. Differences between species may become more or less pronounced over time if saproxyllic communities respond measurably to differences in log chemistry, leading to different rot pathways. Fungi play a major role in forging decay pathways. White-rot decomposed organic matter, which unlike brown-rot produces lignin-decomposing enzymes, is then largely reduced to soluble sugars or other highly bioavailable compounds which are further metabolized by fast growing populations of bacteria. Subsequently, in white rot pathways, nitrogen is utilized and immobilized by white rot and associated bacteria community. In brown rot decay systems a majority of wood-sourced $\mathrm{N}$ is bound with degraded lignin structures, and thus unavailable to bacteria (Martínez et al. 2005). This results in brown-rot dominated systems typically having higher fungi to bacteria ratio, higher C:N ratios because of enrichment by lignin polymers, and greater SOM build-up (Bai et al. 2007; Malik et al. 2016).

This study found measurable differences in $\mathrm{C}$ transfers between coarse wood and soil among three National Forest study sites. Follow-up research to examine log carbon in soil $\mathrm{C}$ fractions of differing recalcitrance would help us understand the stability of carbon in soil derived from log decomposition. Sampling soils at greater depths and horizontal distances could provide insight into the leaching or lateral movement of wood $\mathrm{C}$ within soil matrices. Isotopic analysis of fungal necromass, bacterial cells, or arthropods may provide insight to the metabolic activity of different decomposer guilds and their involvement in sequestering wood $\mathrm{C}$ in forest soils. This research also opens the 
possibility of calculating landscape-scale coarse wood to soil carbon transfers based on established coarse wood volumes across forest habitat types to more accurately model the cycle of terrestrial C.

\subsection{References}

Bai, Z., Q. Ma, Y. Dai, H. Yuan, J. Ye, and W. Yu. 2017. Spatial heterogeneity of SOM concentrations associated with white-rot versus brown-rot wood decay. Nature Scientific Reports, 7(13758).

Butts, S., and W. Mccomb. 2000. Associations of forest-floor vertebrates with coarse Woody debris in managed forests of western oregon. The Journal of Wildlife Management, 64(1): 95-104.

Fry, B. 2006. Stable Isotope Ecology. Springer-Verlag New York.

Gough, C.M., C.S. Vogel, C. Kazanski, L. Nagel, C. E. Flower, and P.S. Curtis (2007), Coarse woody debris and the carbon balance of a north temperate forest, For. Ecol. Manage., 244, 60-67.

Heath, L.S., and J.E. Smith. 2000. An assessment of uncertainty in forest carbon budget projections. Environmental Science \& Policy, 3: 73-82.

Houghton R.A. 2003: revised estimates of the annual net flux of carbon to the atmosphere from changes in land use and land management 1850-2000. Tellus B: Chemical and Physical Meteorology, 55(2): 378-390.

Hu, Z., S.T. Michaletz, D.J. Johnson, N.G. Mcdowell, Z. Huang, X. Zhou, and C. Xu. 2018. Traits drive global wood decomposition rates more than climate. Glob Change Biol., 24(11): 5259:5269.

Huang C., S.N. Goward, J.G. Masek, N. Thomas, Z. Zhu, and J.E. Vogelmann. 2010. An automated approach for reconstructing recent forest disturbance history using dense Landsat time series stacks. Remote Sensing of Environment, 114, 183-198.

Jones, J.R. and N.V. Debyle. 1985. Fire, pages 77- 81. In: N. V. DeByle and R. P 
Winokur, (eds.). Aspen: ecology and management in the Western United States. USDA Forest Service Gen. Tech. Rep. RM-119.

Kappes, H., W. Topp, P. Zach, and J. Kulfan. 2006. Coarse woody debris, soil properties and snails in European primeval forests of different environmental conditions. European Journal of Soil Biology, 42 (3):139-146.

Kueppers, L.A., J. Southon, P. Baer, and J. Harte. 2004. Dead wood biomass and turnover time, measured by radiocarbon, along a subalpine elevation gradients. Oecologia, 141:641-651.

Kurz, W. A., G. Stinson, G. Rampley, C. Dymond, and E. Neilson. 2008. Risk of natural disturbances makes future contribution of canada's forests to the global carbon cycle highly uncertain. Proc. Natl. Acad. Sci. U.S.A., 105: 1551-1555.

Laiho, R. and C.E. Prescott. 1999. The contribution of coarse woody debris to carbon, nitrogen, and phosphorus cycles in three rocky mountain coniferous forests. Canadian Journal Of Forest Research, 29(10): 1592-1603.

Lehmann, J. and M. Kleber. 2015. The contentious nature of soil organic matter. Nature, 528: $60-68$.

Magnússon, R., Tietema, J. Cornelissen, M. Heftig, and K. Kalbitz. 2016. Sequestration of Carbon from coarse woody debris in forest soils. Ecology And Management, 377: 1-15.

Martínez, A., M. Speranza, F. Ruiz-Dueñas, P. Ferreira, S. Camarero, F. Guillén, A. Gutiérrez, and J. del Rio. 2005. Biodegradation of lignocellulosics: microbial, chemical, and enzymatic aspects of the fungal attack of lignin. Int. Microbiol., 8(3): 195-204.

Malik, A.M., S. Chowdhury, V. Schlager, A. Oliver, J. Puissant, P. Vazquez, N. Jehmlich, M. Von Bergen, R. Griffiths, and G. Gleixner. 2016. Soil fungal:bacterial ratios are linked to altered carbon cycling. Front Microbiol, 7(1247).

Manzoni, S., J. Trofymow, R. Jackson, and A. Porporato. 2010. Stoichiometric controls on carbon, nitrogen, and phosphorus dynamics in decomposing litter. Ecological Monographs, 80(1): 89-106.

Mosier, S. E.Kane, D. Richter, E. Lilleskov, M. Jurgensen, A. Burton, and S. Resh. 2017. Interactive effects of climate change and fungal communities on wood-derived carbon in forest soils. Soil Biology \& Biochemistry, 115: 297-309.

Pan, Y., R. Birdsey, J. Fang, R. Houghton, P. Kauppi, W. Kurz, O. Phillips, A. 
Shvidenko, S. Lewis, J. Canadell, A. Rautiainen, S. Sitch, and D. Hayes. 2011. A large and persistent carbon sink in the world's forests. Science, 333: 988-993.

Rabbinage, R., 1993. The ecological background of food production. In: Chadwick, D.J., Marsh, J. (Eds.), Crop Protection and Sustainable Agriculture. Ciba Foundation Symposium, Vol. 177. John \& Wiley and Sons, Chicester, Pp. 2-29.

Rayner, A.D., and L. Boddy. 1988. Fungal Decomposition of Wood: Its Biology And Ecology. John Wiley \& Sons.

Schmidt, M.W., M.S. Torn, S. Abiven, T. Dittmar, G.Guggenberger, I.A.. Janssens, M.Kleber, I. Kögel-K.J. Lehmann, D. Manning, P. Nannipieri, D.P. Rasse, S.Weiner, and S.E. Trumbore. 2011. Persistence of soil organic matter as an ecosystem property. Nature 478: 49-56.

Schimel, J.P. and S.M. Schafer. 2012. Microbial control over carbon cycling in soil. Frontiers In Microbiology, 3(348).

Sturtevant, B., J. Bissonette, J. Long, and D. Roberts. 1997. Coarse woody debris as a Function of age, stand structure, and disturbance in boreal Newfoundland. Ecological Applications, 7(2): 702-712.

Takahashi, M., Y. Sakai, R. Ootomo, and M. Shiozaki. 2000. Establishment of tree seedlings and water-soluble nutrients in coarse woody debris in an old-growth picea-abies forest in Hokkaido, Northern Japan. Canadian Journal of Forest Research, 30(7): 1148-1155.

Woodall, C.W., L.S. Heath, and J.E. Smith. 2008. National inventories of down and dead woody material forest carbon stocks in the United States: challenges and opportunities. Forest Ecology and Management, 256: 221-228.

Woodall, C.W., B.F. Walters, S.N. Oswalt, G.M. Domke, C. Toney, and A.N. Gray. 2013. Biomass and carbon attributes of downed woody materials in forests of the United States. Forest Ecology and Management, 305: 48-59.

Xiang, S., A. Doyle, P. Holden, and J. Schimel. 2008. Drying and rewetting effects on C and $\mathrm{N}$ mineralization and microbial activity in surface and subsurface California grassland soils. Soil Biol. Biochem., 40: 2281-2289.

Yoon, T., H. Chung, R. Kim, N. Noh, K. Seo, S. Lee, W. Jo, Y. Son. 2011. Coarse Woody Debris Mass Dynamics In Temperate Natural Forests Of Mt. Jumbong, Korea. J. Ecol. Field Biol. 34(1): 115-125. 


\section{Conclusion}

Observing northern forest responses to thunderstorm disturbance can inform ecosystem based management of mixed hardwoods by documenting natural processes of regeneration and reorganization in a changing environment. In this research, dense maple seedbanks beneath second growth sugar maple canopy created a highly competitive environment for other seedling species to recruit. Wind gaps up to $1100 \mathrm{~m}^{2}$ in both unmanaged forests as well as forests experiencing single tree selection failed to recruit diverse seedling regeneration. Greater gap frequency in stands with single tree selection led to more canopy openness and light availability than in unmanaged second growth forest or primary old growth. However, gap sizes were not much different in second growth forest than reference primary forest.

The lack of species diversity observed within mid-aged Acer stands, and the apparent resiliency of Acer in preventing other species from taking advantage of canopy gaps, suggests that forest managers attempting to increase species diversity within these stands face a challenging task. Prior to the lumber era, white pine (Pinus strobus) would have been present in sugar maple stands, creating a super canopy as can be observed in some mixed northern hardwood sites today, for example in northern Wisconsin. Pine and other evergreens invite wildlife into mixed hardwoods by providing food and thermal cover and are important to retain in the canopy. These animals in return, by caching or stratifying berries and acorns, play a critical role in the distribution and germination of wild tree seeds. Where absent, planting white pine may help to restore balance in second growth hardwoods, and storm gaps provide prime habitat to do so.

In harvesting sugar maple stands, retaining co-associate species in the canopy is key to maintain and restore diversity in second growth forests. Some species, such as basswood or yellow birch, are especially important in the forest's response to thunderstorm for their role in creating multi-tree gaps, or for regenerating post-storm. Retaining coarse woody debris deposited as windthrow for future 'nurse log' substrate would further facilitate these species' regeneration. Thunderstorms that create canopy gaps in the forest are responsible for depositing substantial volumes of coarse woody debris to the forest floor. We are still developing our understanding of where the carbon 
temporarily sequestered in tree logs is transferred. This study found that after six years of decomposition, $0-10 \%$ of the log's carbon could be traced to the soil. Much larger portions where unaccounted for. There are many unknowns regarding the below-ground carbon cycle in forests. In the sugar maple forest, large trees, known to exchange carbon with fungi in exchange for water and nutrients, may also exchange carbon with seedlings. Ongoing research with FWDE will provide important insight to ecosystem carbon.

In studying the response of sugar maple forests to intermediate storm disturbance, we elicit from wind gaps and the seedlings growing therein a forecast of future canopy composition. Yet, the canopy gap itself may be a poor indicator of future species composition of the forest, and even worse representative of the chronological and geographical scales of diversity that compose the northern hardwood forest. In healthy forests, gaps close swiftly as the newly released light, nutrients, water, and growing space are absorbed by the surrounding individuals. Seedlings have a narrow window of time to successfully recruit to the understory layer, where even then, their succession to the canopy is far from guaranteed. In the observed second growth forests, the seedlings of Acer may have already spent several decades in the deep shade of the presiding canopy. Due to few dominant stems reaching the overstory and subsequent mortality of suppressed individuals, early species composition may be a poor predictor of future canopy composition (Lutz and Halpern 2006).

Plant communities are rarely stable in time or place. A super-disturbance of the Great Lakes region was glaciation. Abrupt warming periods leading to glacial melting have been shown to be a greater disruptive force in vegetation stability than development of the glacier itself (Davis, 1981). The forest community of presettlement western Upper Peninsula was assembled by species favored in the warming climate driving the Wisconsin deglaciation. Sugar maple forest is further derived from this community for its positive response to human disturbances of clear cutting. The intense human intervention associated with the Acer forest type leads to distinguishing the community as an alternative stable state, one of multiple late-successional communities possible given the local climate, geology, and environmental history. 
Reproducing the frequency and intensity scales of natural disturbances is a key step in implementing ecologically-based management of timberlands to drive forward desired successional pathways, maintain niche or locally important wildlife habitat, and sustainably produce timber. Sugar maple decline or decay has been observed in patches across its northeastern and Great Lakes ranges due to various abiotic and biotic stress agents such as extreme weather events, defoliating insects and fungal disease, atmospheric pollutant deposition, and nutritional deficiencies (Horsely et al. 2002; Bal and Storer 2015; Bishop et al. 2015; Nordin 1954). Regeneration failure of sugar maple has also been observed regionally, both in managed and unmanaged stands. Heavy deer browse, replacement by beech in heavy shade, and competition with herbaceous vegetation are some contributing factors (Beaudet et al. 1998; Matonis et al. 2011). As a foundation tree species of northern hardwood forests and a timber economy mainspring, substantial declines would result in catastrophic ecological disturbance and wide scale forest conversion

Species diversity provides an important preemptive defense against the effects of climate change, and may improve net forest productivity and sequestration. A productive forest is more likely to be valued, managed, and protected. Davis (1981) argues that in light of the inherent instability of forest communities over the ages, more attention is due to species and community traits that facilitate rapid change and adaptation, rather than foster stability. Able to live 300 years or more on productive sites, large swaths of second growth Acer forests are nearing middle age. In unmanaged forests, the even-aged canopy will eventually begin to decline and die. The light patterns created by this cohort senescence will be unlike individual or multi tree mortality from storm gaps, and may result in new patters of regeneration. The potential for more frequent severe storms creates even more opportunity for the aging forest to usher in a new generation.

The succession of the second growth maple forest is yet to be witnessed. While new patterns of recruitment and species composition are likely to unfold in the next halfcentury to century given the age and demographic of second growth sugar maple forests, the health of northern ecosystems is less certain. From recent declines in global invertebrate abundance and diversity, to rapid warming of the Great Lakes, global and 
regional environmental change may devastate local ecological processes from pollination to decomposition. In light of pervasive loss of global forest cover, species shifts and declines, and the detrimental effects of these trends to food security, climate stability, and natural capital (Bradshaw et al. 2007; Runyan and D'Odorico 2016; McDowell et al. 2020), healthy sugar maple forests are a regionally significant asset worth protecting.

To adopt an ecosystem-based approach to management of mixed northern hardwoods is to strengthen the connections that weave together the web of life. Habitatconnectivity needs to be considered at the largest scales, such as migratory routes of beneficial insects such as hoverflies (Diptera: Syrphoidea), butterflies and moths (Lepidopteran), dragonflies (Odonates), and bumblebees (Bombus ssp.) from Midwestern prairies to Northwood forests. Wide riparian corridors need to be preserved or planted to protect downstream communities. Cultural connectivity supports this web, and can be strengthened by ecological restoration, equalizing access to nature, and consulting cultural leaders and indigenous ways of knowing. Ecosystem connections are chronological as well. In the forests of Upper Michigan, these connections reach into the ancient past and well beyond human foresight. Ecosystem-based management requires us to respect the time scale of trees.

\subsection{References}

BAL, T.L. AND A.J. STORER. 2015. Evaluation of sugar maple dieback trends in the upper Great Lakes region, p. 119-124. In: Potter, K.M. and B.L. Conkling (eds.). Forest health monitoring: national status, trends and analysis, 2014. General technical report SRS-209. U.S. Department of Agriculture, Forest Service, Southern Research Station, Asheville, North Carolina.

Beaudet, M., C. Messier, D. Paré, J. Brisson, and Y. Bergeron. 1999. Possible mechanisms of sugar maple regeneration failure and replacement by beech in the Boisé-des-Muir old-growth forest, Québec. Écoscience, (6)2: 264-271. 
Bishop, D.A., C.M. Beier, N. Pederson, G.B. Lawrence, J. C. Stella, And T. J. SULLIVAN. 2015. Regional growth decline of sugar maple (Acer saccharum) and its potential causes. Ecosphere, 6(10).

Bradshaw, C.J., N.S. Sodhi, K. PeH, AND B.W. BroOK. 2007. Global evidence that deforestation amplifies flood risk and severity in the developing world. Glob. Change Biol., 13: 2379-2395.

DAVIS M.B. 1981. Quaternary History and the Stability of Forest Communities. In: West D.C., Shugart H.H., Botkin D.B. (eds.). Forest Succession. Springer Advanced Texts in Life Sciences. Springer, New York, NY.

Horsley, S.B., R.P. Long, S.W. BAiley, R.A. Hallett, And P.M. WARgO. 2002. Health of eastern North American sugar maple forests and factors affecting decline. North. J. Appl. For., 19(1): 34-44.

LutZ, JAMES A. AND C.B. HALPERN. 2006. Tree mortality during early forest development: a long-term study of rates, causes, and consequences. Ecological Monographs. 76(2): 257-275.

Matonis, M.S., M.B. Walters, And J. Millington. 2011. Gap-, stand-, and landscapescale factors contribute to sugar maple regeneration after timber harvest. For. Ecol. Manag., 262(2): 286-298.

McDowell, N.G., C.D. Allen, K. Anderson-TeiXeira, B.H. Aukema, B. BondLamberty, L. Chini, J.S. Clark, M. Dietze, C. Grossiord, A. HanburyBrown, G.C. Hurtt, R.B. JACKSOn, D.J. Johnson, L. KuepPers, J.W. Lichstein, K. Ogle, B. Poulter, T. Pugh, R. Seidl, M.G. Turner, M. Uirarte, A.P. WALKer, AND C. XU. 2020. Pervasive shifts in forest dynamics in a changing world. Science, 368(6494).

Nordin, J.V. 1954. Studies in forest pathology: xiii. Decay in sugar maple in the OttawaHuron and Algoma extension forest region of Ontario. Canadian Journal of Botany, 32(1): 221-258.

Runyan, C. And P. D’Odorico. 2016. Global Deforestation. Cambridge University Press. 


\section{Appendix A}

Table 1.1. Stand characteristics of 46 mixed northern hardwood stands in central Houghton County managed by MI-DNR

\begin{tabular}{|c|c|c|c|c|c|c|c|c|}
\hline $\begin{array}{c}\text { Harvest } \\
\text { year }\end{array}$ & $\begin{array}{l}\text { unit } \\
\text { ID }\end{array}$ & ha & $\begin{array}{c}\text { mean } \\
\text { DBH (in.) }\end{array}$ & $\begin{array}{l}\text { species } \\
\text { richness }\end{array}$ & $\begin{array}{l}\text { R.A. Acer } \\
\text { saccharum }\end{array}$ & $\begin{array}{l}\text { slope } \\
\%\end{array}$ & $\begin{array}{l}\text { elevation } \\
\text { (m) }\end{array}$ & $\begin{array}{l}\text { AWS } \\
(\mathrm{cm})\end{array}$ \\
\hline 1988 & $31-04$ & 25 & 14 & 6 & 55 & 7 & 413 & 15 \\
\hline 1995 & $56-03$ & 59 & 14 & 7 & 65 & 13 & 323 & 12 \\
\hline 1997 & $51-06$ & 13 & 12 & 6 & 60 & 2 & 376 & 17 \\
\hline 1997 & $51-23$ & 114 & 12 & 4 & 70 & 3 & 373 & 14 \\
\hline 1997 & $51-29$ & 77 & 8 & 8 & 35 & 3 & 376 & 13 \\
\hline 1997 & 54-04 & 95 & 12 & 9 & 46 & 2 & 376 & 14 \\
\hline 1998 & $51-30$ & 37 & 10 & 6 & 60 & 13 & 395 & 12 \\
\hline 1998 & $53-23$ & 47 & 12 & 6 & 28 & 4 & 371 & 16 \\
\hline 1998 & $53-30$ & 24 & 12 & 6 & 28 & 3 & 370 & 20 \\
\hline 1998 & $55-03$ & 23 & 12 & 5 & 40 & 6 & 361 & 11 \\
\hline 1998 & $55-38$ & 9 & 10 & 7 & 38 & 6 & 373 & 18 \\
\hline 1999 & $55-45$ & 46 & 10 & 4 & 35 & 6 & 378 & 15 \\
\hline 1999 & $55-47$ & 20 & 10 & 4 & 55 & 9 & 375 & 13 \\
\hline 1999 & $55-49$ & 13 & 10 & 4 & 55 & 9 & 376 & 12 \\
\hline 2000 & $31-19$ & 43 & 12 & 9 & 70 & 7 & 392 & 12 \\
\hline 2000 & $55-13$ & 37 & 12 & 5 & 50 & 10 & 406 & 13 \\
\hline 2001 & $31-01$ & 108 & 14 & 6 & 55 & 8 & 426 & 12 \\
\hline 2002 & $31-07$ & 37 & 14 & 6 & 55 & 9 & 414 & 11 \\
\hline 2002 & $31-08$ & 16 & 14 & 6 & 55 & 13 & 398 & 12 \\
\hline 2002 & $32-07$ & 46 & 13 & 5 & 72 & 8 & 439 & 11 \\
\hline 2002 & $45-24$ & 33 & 14 & 6 & 60 & 8 & 351 & 15 \\
\hline 2002 & $45-25$ & 35 & 8 & 5 & 50 & 3 & 369 & 13 \\
\hline 2003 & $50-04$ & 26 & 9 & 5 & 50 & 1 & 369 & 12 \\
\hline
\end{tabular}




\begin{tabular}{|c|c|c|c|c|c|c|}
\hline 2004 & $52-02 \quad 57$ & 12 & 9 & 45 & 2 & 379 \\
\hline 2004 & $52-04 \quad 11$ & 10 & 7 & 45 & 2 & 382 \\
\hline 2004 & $56-31 \quad 11$ & 10 & 6 & 35 & 5 & 366 \\
\hline 2005 & $56-13 \quad 14$ & 10 & 7 & 60 & 11 & 345 \\
\hline 2006 & $50-19 \quad 13$ & 8 & 6 & 50 & 7 & 376 \\
\hline 2006 & $54-16 \quad 10$ & 12 & 5 & 50 & 2 & 382 \\
\hline 2007 & $49-51 \quad 15$ & 12 & 6 & 50 & 3 & 366 \\
\hline 2007 & $51-1227$ & 10 & 6 & 80 & 3 & 380 \\
\hline 2008 & $31-14 \quad 27$ & 12 & 9 & 55 & 6 & 392 \\
\hline 2008 & $51-0344$ & 14 & 3 & 70 & 2 & 374 \\
\hline 2008 & $51-21 \quad 50$ & 10 & 6 & 65 & 1 & 375 \\
\hline 2008 & $53-08 \quad 38$ & 10 & 4 & 40 & 2 & 376 \\
\hline 2008 & $53-20 \quad 52$ & 11 & 5 & 58 & 5 & 372 \\
\hline 2008 & $53-29 \quad 17$ & 14 & 6 & 60 & 6 & 374 \\
\hline 2011 & $32-14 \quad 17$ & 9 & 8 & 60 & 8 & 382 \\
\hline 2011 & $32-1631$ & 12 & 7 & 55 & 12 & 394 \\
\hline 2011 & $32-1933$ & 9 & 5 & 50 & 16 & 417 \\
\hline 2011 & $45-26 \quad 35$ & 14 & 5 & 50 & 7 & 360 \\
\hline 2011 & $55-25 \quad 53$ & 8 & 5 & 45 & 7 & 378 \\
\hline 2013 & $50-2360$ & 8 & 5 & 45 & 3 & 368 \\
\hline 2014 & $50-0645$ & 9 & 7 & 50 & 2 & 370 \\
\hline$<1960$ & $54-123$ & 12 & 6 & 55 & 0 & 380 \\
\hline$<1960$ & TLSP 50 & 18 & 3 & 84 & 7 & 363 \\
\hline
\end{tabular}




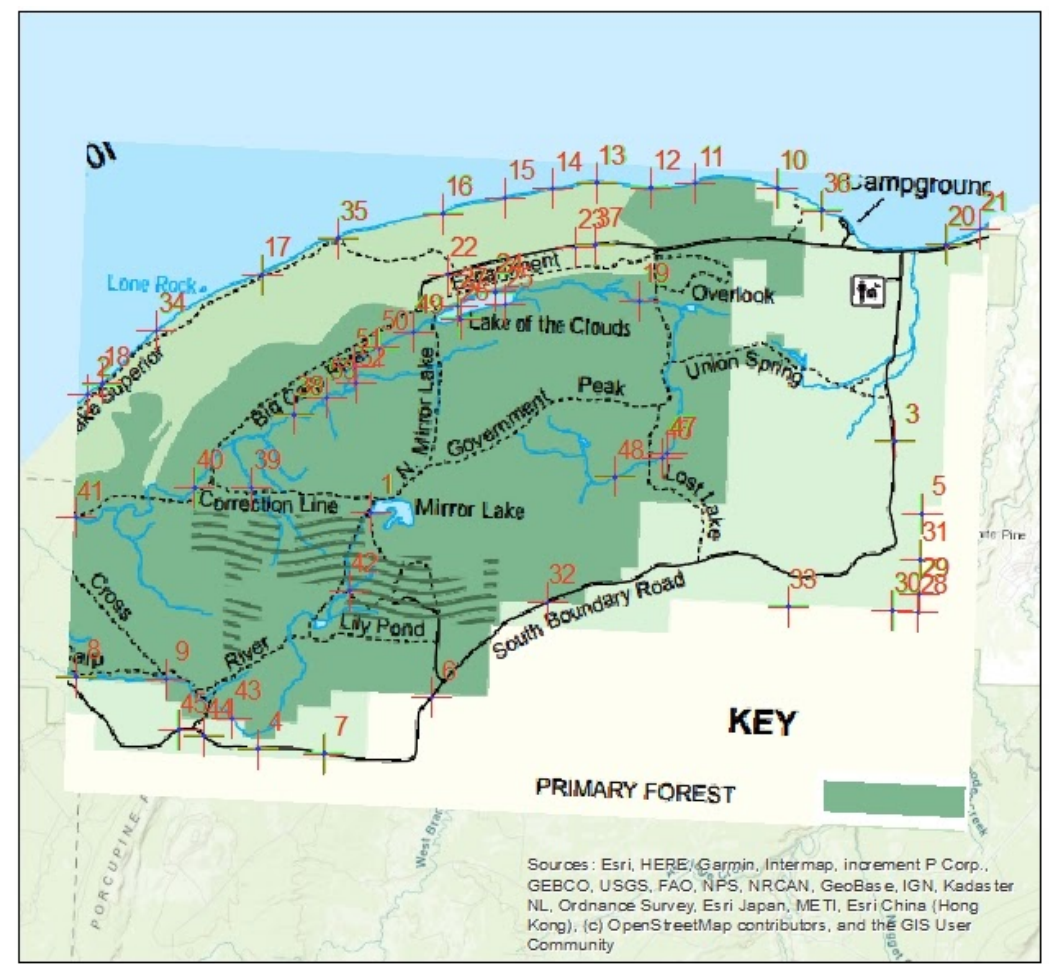

Figure 1.1 Georeferencing MI-DNR primary forest of the Porcupine Mountains Wilderness State Park to ESRI topographic base map. total of 53 tie points and root mean square error $<20 \mathrm{~m}$.

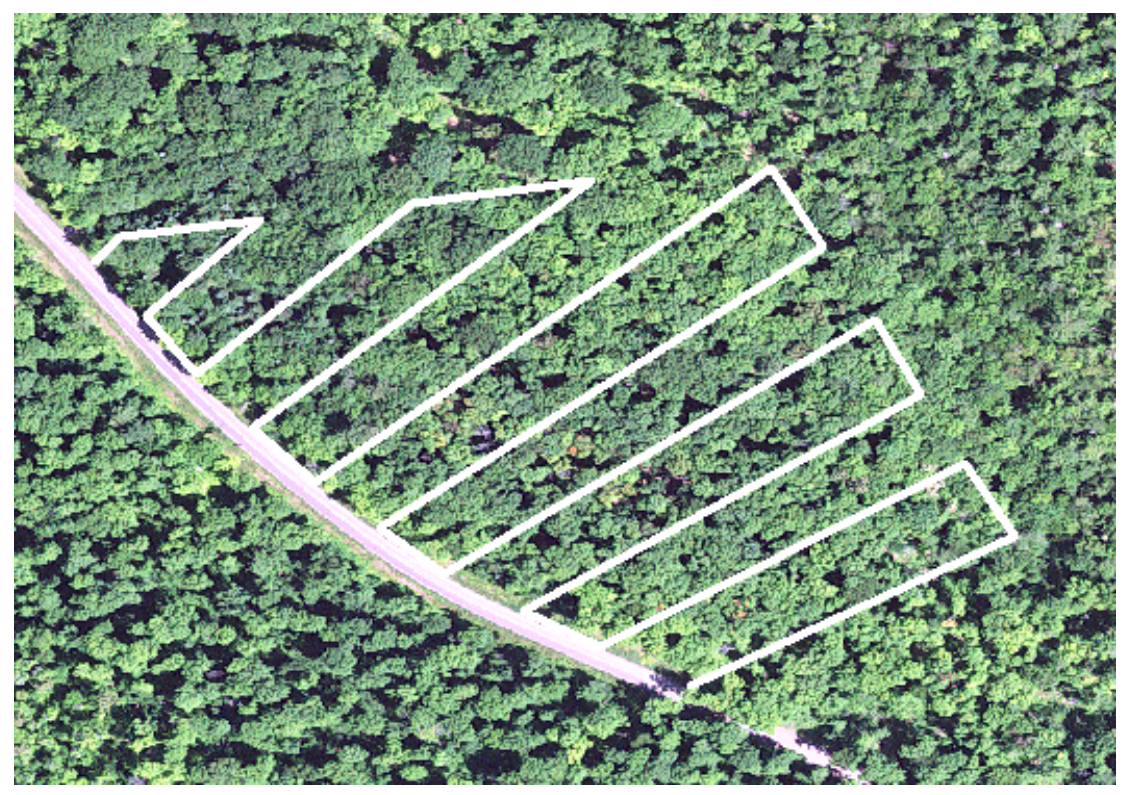

Figure 1.2 Ground-truthing forest canopy gaps along and between 30 meter line transects 


\section{Appendix B}

Table 1.1 Coarse woody debris raw data for unmanaged and managed forest interior (ID

$$
\left.=\mathrm{SC}^{\prime \prime}\right) \text { and wind gaps }
$$

\begin{tabular}{|c|c|c|c|c|c|c|c|}
\hline MI-DNR FCS & ID & $\begin{array}{l}\text { Diam. } \\
\text { eter } \\
(\mathrm{cm})\end{array}$ & $\begin{array}{c}\text { Decay } \\
\text { class }\end{array}$ & $\begin{array}{l}\text { Volume } \\
\left(\mathrm{m}^{3} / \mathrm{ha}\right)\end{array}$ & $\begin{array}{c}\text { Mass } \\
\text { (kg/ha) }\end{array}$ & $\begin{array}{c}\text { Total } \\
\text { Volume } \\
\left(\mathrm{m}^{3} / \mathrm{ha}\right)\end{array}$ & $\begin{array}{c}\text { Total } \\
\text { Mass } \\
(\mathrm{kg} / \mathrm{ha})\end{array}$ \\
\hline $11-54-04$ & $544 \mathrm{SC} 1$ & 6.10 & 2 & 0.76 & 259.86 & 0.13 & 43.31 \\
\hline $11-54-04$ & $544 \mathrm{SC} 1$ & 7.11 & 2 & 1.04 & 353.69 & 0.17 & 58.95 \\
\hline $11-54-04$ & $544 \mathrm{SC} 1$ & 6.35 & 2 & 0.83 & 281.96 & 0.14 & 46.99 \\
\hline $11-54-04$ & $544 \mathrm{SC} 1$ & 11.94 & 2 & 2.93 & 996.57 & 0.49 & 166.09 \\
\hline $11-54-04$ & $544 \mathrm{SC} 1$ & 13.72 & 3 & 3.87 & 580.38 & 0.64 & 96.73 \\
\hline $11-54-04$ & $544 \mathrm{SC} 1$ & 14.99 & 3 & 4.62 & 692.83 & 0.77 & 115.47 \\
\hline $11-54-04$ & $544 \mathrm{SC} 1$ & 9.40 & 3 & 1.82 & 272.47 & 0.30 & 45.41 \\
\hline $11-54-04$ & $544 \mathrm{SC} 1$ & 7.87 & 3 & 1.28 & 191.27 & 0.21 & 31.88 \\
\hline $11-54-04$ & $544 \mathrm{SC} 1$ & 9.65 & 4 & 1.92 & 191.60 & 0.32 & 31.93 \\
\hline $11-54-04$ & $544 \mathrm{SC} 1$ & 20.07 & 4 & 8.28 & 828.11 & 1.38 & 138.02 \\
\hline $11-54-04$ & $544 \mathrm{SC} 1$ & 17.78 & 4 & 6.50 & 650.17 & 1.08 & 108.36 \\
\hline $11-54-04$ & $544 \mathrm{SC} 1$ & 33.53 & 4 & 23.12 & 2311.95 & 3.85 & 385.33 \\
\hline $11-54-04$ & $544 \mathrm{SC} 1$ & 15.24 & 4 & 4.78 & 477.68 & 0.80 & 79.61 \\
\hline $11-54-04$ & $544 \mathrm{SC} 1$ & 8.64 & 4 & 1.53 & 153.39 & 0.26 & 25.56 \\
\hline $11-54-04$ & $544 \mathrm{SC} 2$ & 10.16 & 3 & 2.12 & 318.45 & 0.35 & 53.08 \\
\hline $11-54-04$ & $544 \mathrm{SC} 2$ & 10.16 & 3 & 2.12 & 318.45 & 0.35 & 53.08 \\
\hline $11-54-04$ & $544 \mathrm{SC} 2$ & 6.10 & 3 & 0.76 & 114.64 & 0.13 & 19.11 \\
\hline $11-54-04$ & $544 \mathrm{SC} 2$ & 6.10 & 3 & 0.76 & 114.64 & 0.13 & 19.11 \\
\hline $11-54-04$ & $544 \mathrm{SC} 2$ & 5.33 & 4 & 0.59 & 58.52 & 0.10 & 9.75 \\
\hline $11-54-04$ & $544 \mathrm{SC} 2$ & 8.64 & 4 & 1.53 & 153.39 & 0.26 & 25.56 \\
\hline $11-54-04$ & $544 \mathrm{SC} 2$ & 7.62 & 4 & 1.19 & 119.42 & 0.20 & 19.90 \\
\hline $11-54-04$ & $544 \mathrm{SC} 2$ & 5.08 & 4 & 0.53 & 53.08 & 0.09 & 8.85 \\
\hline $11-55-25$ & $5525 \mathrm{SC} 1$ & 5.59 & 2 & 0.64 & 218.35 & 0.11 & 36.39 \\
\hline $11-55-25$ & $5525 \mathrm{SC} 1$ & 5.33 & 2 & 0.59 & 198.95 & 0.10 & 33.16 \\
\hline $11-55-25$ & $5525 \mathrm{SC} 1$ & 8.64 & 3 & 1.53 & 230.08 & 0.26 & 38.35 \\
\hline $11-55-25$ & $5525 \mathrm{SC} 1$ & 5.08 & 3 & 0.53 & 79.61 & 0.09 & 13.27 \\
\hline $11-55-25$ & $5525 \mathrm{SC} 1$ & 8.38 & 3 & 1.44 & 216.75 & 0.24 & 36.12 \\
\hline $11-55-25$ & $5525 \mathrm{SC} 1$ & 5.08 & 3 & 0.53 & 79.61 & 0.09 & 13.27 \\
\hline $11-55-25$ & $5525 \mathrm{SC} 1$ & 13.21 & 4 & 3.59 & 358.79 & 0.60 & 59.80 \\
\hline $11-55-25$ & $5525 \mathrm{SC} 1$ & 10.16 & 4 & 2.12 & 212.30 & 0.35 & 35.38 \\
\hline $11-55-25$ & $5525 \mathrm{SC} 1$ & 8.64 & 4 & 1.53 & 153.39 & 0.26 & 25.56 \\
\hline $11-55-25$ & $5525 \mathrm{SC} 1$ & 5.33 & 4 & 0.59 & 58.52 & 0.10 & 9.75 \\
\hline $11-55-25$ & $5525 \mathrm{SC} 1$ & 6.10 & 4 & 0.76 & 76.43 & 0.13 & 12.74 \\
\hline $11-55-25$ & $5525 \mathrm{SC} 1$ & 16.76 & 4 & 5.78 & 577.99 & 0.96 & 96.33 \\
\hline $11-55-25$ & $5525 \mathrm{SC} 1$ & 9.91 & 4 & 2.02 & 201.82 & 0.34 & 33.64 \\
\hline $11-55-25$ & $5525 \mathrm{SC} 1$ & 10.16 & 4 & 2.12 & 212.30 & 0.35 & 35.38 \\
\hline $11-55-25$ & $5525 \mathrm{SC} 1$ & 30.48 & 4 & 19.11 & 1910.71 & 3.18 & 318.45 \\
\hline $11-55-25$ & $5525 \mathrm{SC} 1$ & 11.68 & 4 & 2.81 & 280.77 & 0.47 & 46.79 \\
\hline $11-55-25$ & $5525 \mathrm{SC} 1$ & 8.89 & 4 & 1.63 & 162.54 & 0.27 & 27.09 \\
\hline $11-55-25$ & $5525 \mathrm{SC} 1$ & 10.16 & 4 & 2.12 & 212.30 & 0.35 & 35.38 \\
\hline $11-55-25$ & $5525 \mathrm{SC} 1$ & 9.65 & 4 & 1.92 & 191.60 & 0.32 & 31.93 \\
\hline $11-55-25$ & $5525 \mathrm{SC} 2$ & 8.89 & 2 & 1.63 & 552.65 & 0.27 & 92.11 \\
\hline $11-55-25$ & $5525 \mathrm{SC} 2$ & 31.24 & 2 & 20.07 & 6825.28 & 3.35 & 1137.55 \\
\hline $11-55-25$ & $5525 \mathrm{SC} 2$ & 8.64 & 3 & 1.53 & 230.08 & 0.26 & 38.35 \\
\hline $11-55-25$ & $5525 \mathrm{SC} 2$ & 9.65 & 3 & 1.92 & 287.40 & 0.32 & 47.90 \\
\hline $11-55-25$ & $5525 \mathrm{SC} 2$ & 6.35 & 3 & 0.83 & 124.39 & 0.14 & 20.73 \\
\hline $11-55-25$ & $5525 \mathrm{SC} 2$ & 8.89 & 3 & 1.63 & 243.81 & 0.27 & 40.64 \\
\hline $11-55-25$ & $5525 \mathrm{SC} 2$ & 10.16 & 3 & 2.12 & 318.45 & 0.35 & 53.08 \\
\hline $11-55-25$ & $5525 \mathrm{SC} 2$ & 8.64 & 3 & 1.53 & 230.08 & 0.26 & 38.35 \\
\hline $11-55-25$ & $5525 \mathrm{SC} 2$ & 5.59 & 3 & 0.64 & 96.33 & 0.11 & 16.06 \\
\hline $11-55-25$ & $5525 \mathrm{SC} 2$ & 6.10 & 3 & 0.76 & 114.64 & 0.13 & 19.11 \\
\hline $11-55-25$ & $5525 \mathrm{SC} 2$ & 5.59 & 3 & 0.64 & 96.33 & 0.11 & 16.06 \\
\hline $11-55-25$ & $5525 \mathrm{SC} 2$ & 32.26 & 3 & 21.40 & 3210.18 & 3.57 & 535.03 \\
\hline $11-55-25$ & $5525 \mathrm{SC} 2$ & 20.83 & 3 & 8.92 & 1338.29 & 1.49 & 223.05 \\
\hline $11-55-25$ & $5525 \mathrm{SC} 2$ & 5.33 & 3 & 0.59 & 87.77 & 0.10 & 14.63 \\
\hline
\end{tabular}




\begin{tabular}{|c|c|c|c|c|c|c|c|}
\hline $11-55-25$ & $5525 \mathrm{SC} 2$ & 12.45 & 3 & 3.19 & 477.88 & 0.53 & 79.65 \\
\hline $11-55-25$ & $5525 \mathrm{SC} 2$ & 10.67 & 4 & 2.34 & 234.06 & 0.39 & 39.01 \\
\hline $11-55-25$ & $5525 \mathrm{SC} 2$ & 9.91 & 4 & 2.02 & 201.82 & 0.34 & 33.64 \\
\hline $11-55-25$ & $5525 \mathrm{SC} 2$ & 8.38 & 4 & 1.44 & 144.50 & 0.24 & 24.08 \\
\hline $11-55-25$ & $5525 \mathrm{SC} 2$ & 6.86 & 4 & 0.97 & 96.73 & 0.16 & 16.12 \\
\hline $11-55-25$ & $5525 \mathrm{SC} 2$ & 21.08 & 4 & 9.14 & 914.09 & 1.52 & 152.35 \\
\hline $11-55-25$ & $5525 \mathrm{SC} 2$ & 5.84 & 4 & 0.70 & 70.19 & 0.12 & 11.70 \\
\hline $11-55-25$ & $5525 \mathrm{SC} 2$ & 5.59 & 4 & 0.64 & 64.22 & 0.11 & 10.70 \\
\hline $11-55-25$ & $5525 \mathrm{SC} 2$ & 8.38 & 4 & 1.44 & 144.50 & 0.24 & 24.08 \\
\hline $11-55-25$ & $5525 \mathrm{SC} 2$ & 8.38 & 4 & 1.44 & 144.50 & 0.24 & 24.08 \\
\hline $11-55-25$ & $5525 \mathrm{SC} 2$ & 17.78 & 4 & 6.50 & 650.17 & 1.08 & 108.36 \\
\hline $11-55-25$ & $5525 \mathrm{SC} 2$ & 12.45 & 4 & 3.19 & 318.58 & 0.53 & 53.10 \\
\hline $11-55-25$ & Back Interior' & 7.62 & 1 & 1.19 & 585.15 & 0.24 & 117.03 \\
\hline $11-55-25$ & Back Interior' & 8.89 & 1 & 1.63 & 796.46 & 0.33 & 159.29 \\
\hline $11-55-25$ & Back Interior' & 4.57 & 1 & 0.43 & 210.66 & 0.09 & 42.13 \\
\hline $11-55-25$ & Back Interior' & 3.05 & 3 & 0.19 & 28.66 & 0.04 & 5.73 \\
\hline $11-55-25$ & Back Interior' & 6.86 & 3 & 0.97 & 145.09 & 0.19 & 29.02 \\
\hline $11-55-25$ & Back Interior' & 12.70 & 4 & 3.32 & 331.72 & 0.66 & 66.34 \\
\hline $11-55-25$ & Back Interior' & 9.14 & 4 & 1.72 & 171.96 & 0.34 & 34.39 \\
\hline $11-55-25$ & Back Interior' & 8.89 & 4 & 1.63 & 162.54 & 0.33 & 32.51 \\
\hline $11-55-25$ & Back Interior' & 10.16 & 4 & 2.12 & 212.30 & 0.42 & 42.46 \\
\hline $11-55-25$ & Back Interior' & 10.16 & 4 & 2.12 & 212.30 & 0.42 & 42.46 \\
\hline $11-55-25$ & Back Interior' & 9.14 & 4 & 1.72 & 171.96 & 0.34 & 34.39 \\
\hline $11-55-25$ & Back Interior' & 8.13 & 4 & 1.36 & 135.87 & 0.27 & 27.17 \\
\hline $11-55-25$ & $\begin{array}{l}\text { Back Interior' } \\
\text { Branch }\end{array}$ & 17.78 & 4 & 6.50 & 650.17 & 1.30 & 130.03 \\
\hline $11-55-25$ & $\begin{array}{l}\text { Interior } \\
\text { Branch }\end{array}$ & 6.10 & 3 & 0.76 & 114.64 & 0.15 & 22.93 \\
\hline $11-55-25$ & $\begin{array}{l}\text { Interior } \\
\text { Branch }\end{array}$ & 11.18 & 3 & 2.57 & 385.33 & 0.51 & 77.07 \\
\hline $11-55-25$ & $\begin{array}{l}\text { Interior } \\
\text { Branch }\end{array}$ & 12.19 & 4 & 3.06 & 305.71 & 0.61 & 61.14 \\
\hline $11-55-25$ & $\begin{array}{l}\text { Interior } \\
\text { Branch }\end{array}$ & 3.81 & 4 & 0.30 & 29.85 & 0.06 & 5.97 \\
\hline $11-55-25$ & $\begin{array}{l}\text { Interior } \\
\text { Branch }\end{array}$ & 19.30 & 4 & 7.66 & 766.41 & 1.53 & 153.28 \\
\hline $11-55-25$ & $\begin{array}{l}\text { Interior } \\
\text { Branch }\end{array}$ & 4.83 & 4 & 0.48 & 47.90 & 0.10 & 9.58 \\
\hline $11-55-25$ & $\begin{array}{l}\text { Interior } \\
\text { Branch }\end{array}$ & 6.60 & 4 & 0.90 & 89.70 & 0.18 & 17.94 \\
\hline $11-55-25$ & $\begin{array}{l}\text { Interior } \\
\text { Branch }\end{array}$ & 3.81 & 4 & 0.30 & 29.85 & 0.06 & 5.97 \\
\hline $11-55-25$ & $\begin{array}{l}\text { Interior } \\
\text { Branch }\end{array}$ & 5.59 & 4 & 0.64 & 64.22 & 0.13 & 12.84 \\
\hline $11-55-25$ & $\begin{array}{l}\text { Interior } \\
\text { Branch }\end{array}$ & 3.81 & 4 & 0.30 & 29.85 & 0.06 & 5.97 \\
\hline $11-55-25$ & $\begin{array}{l}\text { Interior } \\
\text { Branch }\end{array}$ & 5.59 & 4 & 0.64 & 64.22 & 0.13 & 12.84 \\
\hline $11-55-25$ & $\begin{array}{l}\text { Interior } \\
\text { Branch }\end{array}$ & 9.65 & 4 & 1.92 & 191.60 & 0.38 & 38.32 \\
\hline $11-55-25$ & $\begin{array}{l}\text { Interior } \\
\text { Branch }\end{array}$ & 13.21 & 4 & 3.59 & 358.79 & 0.72 & 71.76 \\
\hline $11-55-25$ & $\begin{array}{l}\text { Interior } \\
\text { Branch }\end{array}$ & 6.35 & 4 & 0.83 & 82.93 & 0.17 & 16.59 \\
\hline $\begin{array}{l}11-55-25 \\
\text { Twin Lakes }\end{array}$ & Interior & 4.57 & 4 & 0.43 & 42.99 & 0.09 & 8.60 \\
\hline $\begin{array}{l}\text { State Park } \\
\text { Twin Lakes }\end{array}$ & TLSC1 & 4.83 & 1 & 0.48 & 234.71 & 0.10 & 46.94 \\
\hline $\begin{array}{l}\text { State Park } \\
\text { Twin Lakes }\end{array}$ & TLSC1 & 5.08 & 1 & 0.53 & 260.07 & 0.11 & 52.01 \\
\hline $\begin{array}{l}\text { State Park } \\
\text { Twin Lakes }\end{array}$ & TLSC1 & 4.83 & 1 & 0.48 & 234.71 & 0.10 & 46.94 \\
\hline $\begin{array}{l}\text { State Park } \\
\text { Twin Lakes }\end{array}$ & TLSC1 & 7.37 & 1 & 1.12 & 546.79 & 0.22 & 109.36 \\
\hline $\begin{array}{l}\text { State Park } \\
\text { Twin Lakes }\end{array}$ & TLSC1 & 6.35 & 1 & 0.83 & 406.36 & 0.17 & 81.27 \\
\hline State Park & TLSC1 & 35.31 & 1 & 25.64 & 12561.95 & 5.13 & 2512.39 \\
\hline
\end{tabular}




\begin{tabular}{|c|c|c|c|c|c|c|c|}
\hline \multicolumn{8}{|l|}{ Twin Lakes } \\
\hline $\begin{array}{l}\text { State Park } \\
\text { Twin Lakes }\end{array}$ & TLSC1 & 35.31 & 1 & 25.64 & 12561.95 & 5.13 & 2512.39 \\
\hline $\begin{array}{l}\text { State Park } \\
\text { Twin Lakes }\end{array}$ & TLSC1 & 7.37 & 2 & 1.12 & 379.41 & 0.22 & 75.88 \\
\hline $\begin{array}{l}\text { State Park } \\
\text { Twin Lakes }\end{array}$ & TLSC1 & 8.64 & 2 & 1.53 & 521.52 & 0.31 & 104.30 \\
\hline $\begin{array}{l}\text { State Park } \\
\text { Twin Lakes }\end{array}$ & TLSC1 & 9.40 & 2 & 1.82 & 617.61 & 0.36 & 123.52 \\
\hline $\begin{array}{l}\text { State Park } \\
\text { Twin Lakes }\end{array}$ & TLSC1 & 3.56 & 2 & 0.26 & 88.42 & 0.05 & 17.68 \\
\hline $\begin{array}{l}\text { State Park } \\
\text { Twin Lakes }\end{array}$ & TLSC1 & 3.81 & 2 & 0.30 & 101.51 & 0.06 & 20.30 \\
\hline $\begin{array}{l}\text { State Park } \\
\text { Twin Lakes }\end{array}$ & TLSC1 & 6.35 & 2 & 0.83 & 281.96 & 0.17 & 56.39 \\
\hline $\begin{array}{l}\text { State Park } \\
\text { Twin Lakes }\end{array}$ & TLSC1 & 18.80 & 2 & 7.27 & 2470.44 & 1.45 & 494.09 \\
\hline $\begin{array}{l}\text { State Park } \\
\text { Twin Lakes }\end{array}$ & TLSC1 & 10.41 & 2 & 2.23 & 758.36 & 0.45 & 151.67 \\
\hline $\begin{array}{l}\text { State Park } \\
\text { Twin Lakes }\end{array}$ & TLSC1 & 6.86 & 2 & 0.97 & 328.88 & 0.19 & 65.78 \\
\hline $\begin{array}{l}\text { State Park } \\
\text { Twin Lakes }\end{array}$ & TLSC1 & 6.86 & 2 & 0.97 & 328.88 & 0.19 & 65.78 \\
\hline $\begin{array}{l}\text { State Park } \\
\text { Twin Lakes }\end{array}$ & TLSC1 & 6.60 & 3 & 0.90 & 134.55 & 0.18 & 26.91 \\
\hline $\begin{array}{l}\text { State Park } \\
\text { Twin Lakes }\end{array}$ & TLSC1 & 24.13 & 3 & 11.98 & 1796.26 & 2.40 & 359.25 \\
\hline $\begin{array}{l}\text { State Park } \\
\text { Twin Lakes }\end{array}$ & TLSC1 & 7.62 & 3 & 1.19 & 179.13 & 0.24 & 35.83 \\
\hline $\begin{array}{l}\text { State Park } \\
\text { Twin Lakes }\end{array}$ & TLSC1 & 7.62 & 3 & 1.19 & 179.13 & 0.24 & 35.83 \\
\hline $\begin{array}{l}\text { State Park } \\
\text { Twin Lakes }\end{array}$ & TLSC1 & 6.60 & 4 & 0.90 & 89.70 & 0.18 & 17.94 \\
\hline $\begin{array}{l}\text { State Park } \\
\text { Twin Lakes }\end{array}$ & TLSC1 & 4.83 & 4 & 0.48 & 47.90 & 0.10 & 9.58 \\
\hline $\begin{array}{l}\text { State Park } \\
\text { Twin Lakes }\end{array}$ & TLSC1 & 11.94 & 4 & 2.93 & 293.11 & 0.59 & 58.62 \\
\hline $\begin{array}{l}\text { State Park } \\
\text { Twin Lakes }\end{array}$ & TLSC2 & 16.26 & 1 & 5.43 & 2663.10 & 1.09 & 532.62 \\
\hline $\begin{array}{l}\text { State Park } \\
\text { Twin Lakes }\end{array}$ & TLSC2 & 6.10 & 1 & 0.76 & 374.50 & 0.15 & 74.90 \\
\hline $\begin{array}{l}\text { State Park } \\
\text { Twin Lakes }\end{array}$ & TLSC2 & 6.86 & 1 & 0.97 & 473.97 & 0.19 & 94.79 \\
\hline $\begin{array}{l}\text { State Park } \\
\text { Twin Lakes }\end{array}$ & TLSC2 & 5.84 & 1 & 0.70 & 343.94 & 0.14 & 68.79 \\
\hline $\begin{array}{l}\text { State Park } \\
\text { Twin Lakes }\end{array}$ & TLSC2 & 6.60 & 1 & 0.90 & 439.52 & 0.18 & 87.90 \\
\hline $\begin{array}{l}\text { State Park } \\
\text { Twin Lakes }\end{array}$ & TLSC2 & 3.56 & 1 & 0.26 & 127.43 & 0.05 & 25.49 \\
\hline $\begin{array}{l}\text { State Park } \\
\text { Twin Lakes }\end{array}$ & TLSC2 & 3.56 & 1 & 0.26 & 127.43 & 0.05 & 25.49 \\
\hline $\begin{array}{l}\text { State Park } \\
\text { Twin Lakes }\end{array}$ & TLSC2 & 5.33 & 1 & 0.59 & 286.73 & 0.12 & 57.35 \\
\hline $\begin{array}{l}\text { State Park } \\
\text { Twin Lakes }\end{array}$ & TLSC2 & 9.14 & 2 & 1.72 & 584.68 & 0.34 & 116.94 \\
\hline $\begin{array}{l}\text { State Park } \\
\text { Twin Lakes }\end{array}$ & TLSC2 & 8.89 & 2 & 1.63 & 552.65 & 0.33 & 110.53 \\
\hline $\begin{array}{l}\text { State Park } \\
\text { Twin Lakes }\end{array}$ & TLSC2 & 4.32 & 3 & 0.38 & 57.52 & 0.08 & 11.50 \\
\hline $\begin{array}{l}\text { State Park } \\
\text { Twin Lakes }\end{array}$ & TLSC2 & 15.24 & 4 & 4.78 & 477.68 & 0.96 & 95.54 \\
\hline $\begin{array}{l}\text { State Park } \\
\text { Twin Lakes }\end{array}$ & TLSC2 & 27.94 & 4 & 16.06 & 1605.52 & 3.21 & 321.10 \\
\hline $\begin{array}{l}\text { State Park } \\
\text { Twin Lakes }\end{array}$ & TLSC3 & 5.33 & 1 & 0.59 & 286.73 & 0.12 & 57.35 \\
\hline State Park & TLSC3 & 6.35 & 1 & 0.83 & 406.36 & 0.17 & 81.27 \\
\hline
\end{tabular}




\begin{tabular}{|c|c|c|c|c|c|c|c|}
\hline $\begin{array}{l}\text { Twin Lakes } \\
\text { State Park } \\
\text { Twin Lakes }\end{array}$ & TLSC3 & 12.19 & 1 & 3.06 & 1497.99 & 0.61 & 299.60 \\
\hline $\begin{array}{l}\text { State Park } \\
\text { Twin Lakes }\end{array}$ & TLSC3 & 12.95 & 1 & 3.45 & 1691.09 & 0.69 & 338.22 \\
\hline $\begin{array}{l}\text { State Park } \\
\text { Twin Lakes }\end{array}$ & TLSC3 & 25.91 & 1 & 13.80 & 6764.38 & 2.76 & 1352.88 \\
\hline $\begin{array}{l}\text { State Park } \\
\text { Twin Lakes }\end{array}$ & TLSC3 & 8.38 & 1 & 1.44 & 708.04 & 0.29 & 141.61 \\
\hline $\begin{array}{l}\text { State Park } \\
\text { Twin Lakes }\end{array}$ & TLSC3 & 13.46 & 3 & 3.73 & 559.08 & 0.75 & 111.82 \\
\hline $\begin{array}{l}\text { State Park } \\
\text { Twin Lakes }\end{array}$ & TLSC3 & 6.35 & 3 & 0.83 & 124.39 & 0.17 & 24.88 \\
\hline State Park & $\begin{array}{l}\text { TLSC3 } \\
\text { Chickaree }\end{array}$ & 10.67 & 4 & 2.34 & 234.06 & 0.47 & 46.81 \\
\hline $11-54-13$ & $\begin{array}{l}\text { Interior } \\
\text { Chickaree }\end{array}$ & 2.79 & 1 & 0.16 & 78.67 & 0.03 & 13.11 \\
\hline $11-54-13$ & $\begin{array}{l}\text { Interior } \\
\text { Chickaree }\end{array}$ & 3.81 & 1 & 0.30 & 146.29 & 0.05 & 24.38 \\
\hline $11-54-13$ & $\begin{array}{l}\text { Interior } \\
\text { Chickaree }\end{array}$ & 3.56 & 1 & 0.26 & 127.43 & 0.04 & 21.24 \\
\hline $11-54-13$ & $\begin{array}{l}\text { Interior } \\
\text { Chickaree }\end{array}$ & 23.88 & 1 & 11.72 & 5744.91 & 1.95 & 957.48 \\
\hline $11-54-13$ & $\begin{array}{l}\text { Interior } \\
\text { Chickaree }\end{array}$ & 11.68 & 1 & 2.81 & 1375.76 & 0.47 & 229.29 \\
\hline $11-54-13$ & $\begin{array}{l}\text { Interior } \\
\text { Chickaree }\end{array}$ & 3.05 & 1 & 0.19 & 93.62 & 0.03 & 15.60 \\
\hline $11-54-13$ & $\begin{array}{l}\text { Interior } \\
\text { Chickaree }\end{array}$ & 3.81 & 1 & 0.30 & 146.29 & 0.05 & 24.38 \\
\hline $11-54-13$ & $\begin{array}{l}\text { Interior } \\
\text { Chickaree }\end{array}$ & 4.57 & 3 & 0.43 & 64.49 & 0.07 & 10.75 \\
\hline $11-54-13$ & $\begin{array}{l}\text { Interior } \\
\text { Chickaree }\end{array}$ & 4.06 & 3 & 0.34 & 50.95 & 0.06 & 8.49 \\
\hline $11-54-13$ & $\begin{array}{l}\text { Interior } \\
\text { Chickaree }\end{array}$ & 4.32 & 3 & 0.38 & 57.52 & 0.06 & 9.59 \\
\hline $11-54-13$ & $\begin{array}{l}\text { Interior } \\
\text { Chickaree }\end{array}$ & 2.79 & 3 & 0.16 & 24.08 & 0.03 & 4.01 \\
\hline $11-54-13$ & $\begin{array}{l}\text { Interior } \\
\text { Chickaree }\end{array}$ & 5.59 & 3 & 0.64 & 96.33 & 0.11 & 16.06 \\
\hline $11-54-13$ & $\begin{array}{l}\text { Interior } \\
\text { Chickaree }\end{array}$ & 3.81 & 3 & 0.30 & 44.78 & 0.05 & 7.46 \\
\hline $11-54-13$ & $\begin{array}{l}\text { Interior } \\
\text { Chickaree }\end{array}$ & 2.79 & 3 & 0.16 & 24.08 & 0.03 & 4.01 \\
\hline $11-54-13$ & $\begin{array}{l}\text { Interior } \\
\text { Chickaree }\end{array}$ & 34.54 & 4 & 24.54 & 2454.20 & 4.09 & 409.03 \\
\hline $11-54-13$ & $\begin{array}{l}\text { Interior } \\
\text { Chickaree }\end{array}$ & 17.78 & 4 & 6.50 & 650.17 & 1.08 & 108.36 \\
\hline $11-54-13$ & $\begin{array}{l}\text { Interior } \\
\text { Chickaree }\end{array}$ & 15.24 & 4 & 4.78 & 477.68 & 0.80 & 79.61 \\
\hline $11-54-13$ & $\begin{array}{l}\text { Interior } \\
\text { Chickaree }\end{array}$ & 3.05 & 4 & 0.19 & 19.11 & 0.03 & 3.18 \\
\hline $11-54-13$ & $\begin{array}{l}\text { Interior } \\
\text { Chickaree }\end{array}$ & 5.59 & 4 & 0.64 & 64.22 & 0.11 & 10.70 \\
\hline $11-54-13$ & $\begin{array}{l}\text { Interior } \\
\text { Chickaree }\end{array}$ & 5.33 & 4 & 0.59 & 58.52 & 0.10 & 9.75 \\
\hline $11-54-13$ & $\begin{array}{l}\text { Interior } \\
\text { Chickaree }\end{array}$ & 3.81 & 4 & 0.30 & 29.85 & 0.05 & 4.98 \\
\hline $11-54-13$ & $\begin{array}{l}\text { Interior } \\
\text { Chickaree }\end{array}$ & 10.16 & 4 & 2.12 & 212.30 & 0.35 & 35.38 \\
\hline $11-54-13$ & Interior & 9.40 & 4 & 1.82 & 181.65 & 0.30 & 30.27 \\
\hline $11-54-13$ & Conus Interior & 3.30 & 1 & 0.22 & 109.88 & 0.04 & 18.31 \\
\hline $11-54-13$ & Conus Interior & 4.32 & 1 & 0.38 & 187.90 & 0.06 & 31.32 \\
\hline $11-54-13$ & Conus Interior & 4.83 & 2 & 0.48 & 162.86 & 0.08 & 27.14 \\
\hline $11-54-13$ & Conus Interior & 5.08 & 2 & 0.53 & 180.46 & 0.09 & 30.08 \\
\hline $11-54-13$ & Conus Interior & 5.08 & 2 & 0.53 & 180.46 & 0.09 & 30.08 \\
\hline $11-54-13$ & Conus Interior & 13.72 & 2 & 3.87 & 1315.52 & 0.64 & 219.25 \\
\hline $11-54-13$ & Conus Interior & 14.22 & 2 & 4.16 & 1414.77 & 0.69 & 235.80 \\
\hline
\end{tabular}




\begin{tabular}{|c|c|c|c|c|c|c|c|}
\hline $11-54-13$ & Conus Interior & 20.07 & 2 & 8.28 & 2815.56 & 1.38 & 469.26 \\
\hline $11-54-13$ & Conus Interior & 7.11 & 2 & 1.04 & 353.69 & 0.17 & 58.95 \\
\hline $11-54-13$ & Conus Interior & 5.33 & 3 & 0.59 & 87.77 & 0.10 & 14.63 \\
\hline $11-54-13$ & Conus Interior & 6.35 & 3 & 0.83 & 124.39 & 0.14 & 20.73 \\
\hline $11-54-13$ & Conus Interior & 10.16 & 4 & 2.12 & 212.30 & 0.35 & 35.38 \\
\hline $11-54-13$ & Conus Interior & 7.37 & 4 & 1.12 & 111.59 & 0.19 & 18.60 \\
\hline $11-54-13$ & $5413 \mathrm{G} 1$ & 5.33 & 1 & 0.59 & 286.73 & 0.12 & 57.35 \\
\hline $11-54-13$ & $5413 \mathrm{G} 1$ & 39.12 & 1 & 31.47 & 15419.45 & 6.29 & 3083.89 \\
\hline $11-54-13$ & $5413 \mathrm{G} 1$ & 6.35 & 1 & 0.83 & 406.36 & 0.17 & 81.27 \\
\hline $11-54-13$ & $5413 \mathrm{G} 1$ & 5.08 & 1 & 0.53 & 260.07 & 0.11 & 52.01 \\
\hline $11-54-13$ & 5413G1 & 5.08 & 1 & 0.53 & 260.07 & 0.11 & 52.01 \\
\hline $11-54-13$ & 5413G1 & 25.91 & 1 & 13.80 & 6764.38 & 2.76 & 1352.88 \\
\hline $11-54-13$ & 5413G1 & 20.32 & 1 & 8.49 & 4161.09 & 1.70 & 832.22 \\
\hline $11-54-13$ & 5413G1 & 12.45 & 1 & 3.19 & 1561.06 & 0.64 & 312.21 \\
\hline $11-54-13$ & $5413 \mathrm{G} 1$ & 15.24 & 1 & 4.78 & 2340.61 & 0.96 & 468.12 \\
\hline $11-54-13$ & 5413G1 & 37.08 & 1 & 28.28 & 13859.04 & 5.66 & 2771.81 \\
\hline $11-54-13$ & $5413 \mathrm{G} 1$ & 34.29 & 1 & 24.18 & 11849.36 & 4.84 & 2369.87 \\
\hline $11-54-13$ & 5413G1 & 11.18 & 2 & 2.57 & 873.40 & 0.51 & 174.68 \\
\hline $11-54-13$ & $5413 \mathrm{G} 1$ & 7.11 & 2 & 1.04 & 353.69 & 0.21 & 70.74 \\
\hline $11-54-13$ & 5413G1 & 7.62 & 3 & 1.19 & 179.13 & 0.24 & 35.83 \\
\hline $11-54-13$ & $5413 \mathrm{G} 1$ & 10.16 & 3 & 2.12 & 318.45 & 0.42 & 63.69 \\
\hline $11-54-13$ & $5413 \mathrm{G} 1$ & 6.60 & 3 & 0.90 & 134.55 & 0.18 & 26.91 \\
\hline $11-54-13$ & $5413 \mathrm{G} 1$ & 5.59 & 3 & 0.64 & 96.33 & 0.13 & 19.27 \\
\hline $11-54-13$ & $5413 \mathrm{G} 1$ & 5.08 & 3 & 0.53 & 79.61 & 0.11 & 15.92 \\
\hline $11-54-13$ & $5413 \mathrm{G} 1$ & 16.51 & 4 & 5.61 & 560.61 & 1.12 & 112.12 \\
\hline $11-54-13$ & 5413G1 & 8.89 & 4 & 1.63 & 162.54 & 0.33 & 32.51 \\
\hline $11-54-13$ & $5413 \mathrm{G} 1$ & 5.08 & 4 & 0.53 & 53.08 & 0.11 & 10.62 \\
\hline $11-54-13$ & $5413 \mathrm{G} 1$ & 9.65 & 4 & 1.92 & 191.60 & 0.38 & 38.32 \\
\hline $11-54-13$ & $5413 \mathrm{G} 2$ & 13.97 & 1 & 4.01 & 1966.77 & 0.80 & 393.35 \\
\hline $11-54-13$ & Cherry Gap & 6.35 & 1 & 0.83 & 406.36 & 0.17 & 81.27 \\
\hline $11-54-13$ & Cherry Gap & 12.45 & 2 & 3.19 & 1083.18 & 0.64 & 216.64 \\
\hline $11-54-13$ & Cherry Gap & 12.70 & 2 & 3.32 & 1127.85 & 0.66 & 225.57 \\
\hline $11-54-13$ & Cherry Gap & 10.67 & 2 & 2.34 & 795.81 & 0.47 & 159.16 \\
\hline $11-54-13$ & Cherry Gap & 18.29 & 2 & 6.88 & 2338.70 & 1.38 & 467.74 \\
\hline $11-54-13$ & Cherry Gap & 25.65 & 2 & 13.54 & 4602.07 & 2.71 & 920.41 \\
\hline $11-54-13$ & Cherry Gap & 30.23 & 2 & 18.79 & 6388.58 & 3.76 & 1277.72 \\
\hline $11-54-13$ & Cherry Gap & 3.56 & 2 & 0.26 & 88.42 & 0.05 & 17.68 \\
\hline $11-54-13$ & Cherry Gap & 3.05 & 2 & 0.19 & 64.96 & 0.04 & 12.99 \\
\hline $11-54-13$ & Cherry Gap & 4.57 & 2 & 0.43 & 146.17 & 0.09 & 29.23 \\
\hline $11-54-13$ & Cherry Gap & 4.32 & 2 & 0.38 & 130.38 & 0.08 & 26.08 \\
\hline $11-54-13$ & Cherry Gap & 7.11 & 2 & 1.04 & 353.69 & 0.21 & 70.74 \\
\hline $11-54-13$ & Cherry Gap & 5.08 & 2 & 0.53 & 180.46 & 0.11 & 36.09 \\
\hline $11-54-13$ & Cherry Gap & 5.08 & 2 & 0.53 & 180.46 & 0.11 & 36.09 \\
\hline $11-54-13$ & Cherry Gap & 5.33 & 2 & 0.59 & 198.95 & 0.12 & 39.79 \\
\hline $11-54-13$ & Cherry Gap & 4.32 & 2 & 0.38 & 130.38 & 0.08 & 26.08 \\
\hline $11-54-13$ & Cherry Gap & 8.13 & 3 & 1.36 & 203.81 & 0.27 & 40.76 \\
\hline $11-54-13$ & Cherry Gap & 9.14 & 3 & 1.72 & 257.95 & 0.34 & 51.59 \\
\hline $11-54-13$ & Cherry Gap & 15.49 & 3 & 4.94 & 740.60 & 0.99 & 148.12 \\
\hline $11-54-13$ & Cherry Gap & 12.95 & 3 & 3.45 & 517.68 & 0.69 & 103.54 \\
\hline $11-54-13$ & Cherry Gap & 7.62 & 3 & 1.19 & 179.13 & 0.24 & 35.83 \\
\hline $11-54-13$ & Cherry Gap & 9.91 & 3 & 2.02 & 302.73 & 0.40 & 60.55 \\
\hline $11-54-13$ & Cherry Gap & 5.84 & 3 & 0.70 & 105.29 & 0.14 & 21.06 \\
\hline $11-54-13$ & Cherry Gap & 6.10 & 3 & 0.76 & 114.64 & 0.15 & 22.93 \\
\hline $11-54-13$ & Cherry Gap & 4.06 & 3 & 0.34 & 50.95 & 0.07 & 10.19 \\
\hline $11-54-13$ & Cherry Gap & 4.32 & 3 & 0.38 & 57.52 & 0.08 & 11.50 \\
\hline $11-54-13$ & Cherry Gap & 4.06 & 3 & 0.34 & 50.95 & 0.07 & 10.19 \\
\hline $11-54-13$ & Cherry Gap & 4.06 & 3 & 0.34 & 50.95 & 0.07 & 10.19 \\
\hline $11-54-13$ & Cherry Gap & 7.11 & 3 & 1.04 & 156.04 & 0.21 & 31.21 \\
\hline $11-54-13$ & Cherry Gap & 8.38 & 3 & 1.44 & 216.75 & 0.29 & 43.35 \\
\hline $11-54-13$ & Cherry Gap & 8.89 & 3 & 1.63 & 243.81 & 0.33 & 48.76 \\
\hline $11-54-13$ & Cherry Gap & 4.32 & 3 & 0.38 & 57.52 & 0.08 & 11.50 \\
\hline $11-54-13$ & Cherry Gap & 4.57 & 3 & 0.43 & 64.49 & 0.09 & 12.90 \\
\hline $11-54-13$ & Cherry Gap & 5.33 & 3 & 0.59 & 87.77 & 0.12 & 17.55 \\
\hline $11-54-13$ & Cherry Gap & 5.33 & 3 & 0.59 & 87.77 & 0.12 & 17.55 \\
\hline $11-54-13$ & Cherry Gap & 12.70 & 4 & 3.32 & 331.72 & 0.66 & 66.34 \\
\hline $11-54-13$ & Cherry Gap & 13.46 & 4 & 3.73 & 372.72 & 0.75 & 74.54 \\
\hline $11-54-13$ & Cherry Gap & 5.08 & 4 & 0.53 & 53.08 & 0.11 & 10.62 \\
\hline
\end{tabular}




\begin{tabular}{|c|c|c|c|c|c|c|c|}
\hline $11-54-12$ & Big Pine Gap & 52.07 & 1 & 55.76 & 27323.43 & 11.15 & 5464.69 \\
\hline $11-54-12$ & Big Pine Gap & 30.73 & 1 & 19.43 & 9519.15 & 3.89 & 1903.83 \\
\hline $11-54-12$ & Big Pine Gap & 29.21 & 1 & 17.55 & 8598.51 & 3.51 & 1719.70 \\
\hline $11-54-12$ & Big Pine Gap & 41.15 & 1 & 34.82 & 17063.08 & 6.96 & 3412.62 \\
\hline $11-54-12$ & Big Pine Gap & 43.18 & 1 & 38.35 & 18789.93 & 7.67 & 3757.99 \\
\hline $11-54-12$ & Big Pine Gap & 5.08 & 1 & 0.53 & 260.07 & 0.11 & 52.01 \\
\hline $11-54-12$ & Big Pine Gap & 2.79 & 1 & 0.16 & 78.67 & 0.03 & 15.73 \\
\hline $11-54-12$ & Big Pine Gap & 3.81 & 3 & 0.30 & 44.78 & 0.06 & 8.96 \\
\hline $11-54-12$ & Big Pine Gap & 5.08 & 4 & 0.53 & 53.08 & 0.11 & 10.62 \\
\hline $11-54-12$ & Big Pine Gap & 6.35 & 4 & 0.83 & 82.93 & 0.17 & 16.59 \\
\hline $11-54-12$ & Big Pine Gap & 15.24 & 4 & 4.78 & 477.68 & 0.96 & 95.54 \\
\hline $11-54-12$ & Big Pine Gap & 10.67 & 4 & 2.34 & 234.06 & 0.47 & 46.81 \\
\hline $11-54-12$ & Big Pine Gap & 3.30 & 4 & 0.22 & 22.42 & 0.04 & 4.48 \\
\hline $11-54-12$ & Big Pine Gap & 9.65 & 4 & 1.92 & 191.60 & 0.38 & 38.32 \\
\hline $11-54-12$ & Big Pine Gap & 9.65 & 4 & 1.92 & 191.60 & 0.38 & 38.32 \\
\hline $11-54-12$ & Big Pine Gap & 6.10 & 4 & 0.76 & 76.43 & 0.15 & 15.29 \\
\hline $11-54-12$ & Big Pine Gap & 15.24 & 4 & 4.78 & 477.68 & 0.96 & 95.54 \\
\hline $11-54-12$ & Belle Gap & 3.81 & 1 & 0.30 & 146.29 & 0.06 & 29.26 \\
\hline $11-54-12$ & Belle Gap & 4.06 & 1 & 0.34 & 166.44 & 0.07 & 33.29 \\
\hline $11-54-12$ & Belle Gap & 10.67 & 1 & 2.34 & 1146.90 & 0.47 & 229.38 \\
\hline $11-54-12$ & Belle Gap & 6.35 & 2 & 0.83 & 281.96 & 0.17 & 56.39 \\
\hline $11-54-12$ & Belle Gap & 3.30 & 2 & 0.22 & 76.24 & 0.04 & 15.25 \\
\hline $11-54-12$ & Belle Gap & 4.57 & 2 & 0.43 & 146.17 & 0.09 & 29.23 \\
\hline $11-54-12$ & Belle Gap & 4.32 & 3 & 0.38 & 57.52 & 0.08 & 11.50 \\
\hline $11-54-12$ & Belle Gap & 4.06 & 3 & 0.34 & 50.95 & 0.07 & 10.19 \\
\hline $11-54-12$ & Belle Gap & 4.32 & 3 & 0.38 & 57.52 & 0.08 & 11.50 \\
\hline $11-54-12$ & Belle Gap & 12.19 & 3 & 3.06 & 458.57 & 0.61 & 91.71 \\
\hline $11-54-12$ & Belle Gap & 5.59 & 3 & 0.64 & 96.33 & 0.13 & 19.27 \\
\hline $\begin{array}{l}\text { 11-54-12 } \\
\text { Twin Lakes }\end{array}$ & Belle Gap & 14.73 & 3 & 4.46 & 669.54 & 0.89 & 133.91 \\
\hline $\begin{array}{l}\text { State Park } \\
\text { Twin Lakes }\end{array}$ & TLG1 & 26.42 & 1 & 14.35 & 7032.25 & 2.87 & 1406.45 \\
\hline $\begin{array}{l}\text { State Park } \\
\text { Twin Lakes }\end{array}$ & TLG1 & 42.67 & 1 & 37.45 & 18350.42 & 7.49 & 3670.08 \\
\hline $\begin{array}{l}\text { State Park } \\
\text { Twin Lakes }\end{array}$ & TLG1 & 37.59 & 1 & 29.06 & 14241.34 & 5.81 & 2848.27 \\
\hline $\begin{array}{l}\text { State Park } \\
\text { Twin Lakes }\end{array}$ & TLG1 & 15.24 & 1 & 4.78 & 2340.61 & 0.96 & 468.12 \\
\hline $\begin{array}{l}\text { State Park } \\
\text { Twin Lakes }\end{array}$ & TLG1 & 10.16 & 1 & 2.12 & 1040.27 & 0.42 & 208.05 \\
\hline $\begin{array}{l}\text { State Park } \\
\text { Twin Lakes }\end{array}$ & TLG1 & 9.14 & 1 & 1.72 & 842.62 & 0.34 & 168.52 \\
\hline $\begin{array}{l}\text { State Park } \\
\text { Twin Lakes }\end{array}$ & TLG1 & 6.10 & 1 & 0.76 & 374.50 & 0.15 & 74.90 \\
\hline $\begin{array}{l}\text { State Park } \\
\text { Twin Lakes }\end{array}$ & TLG1 & 5.33 & 1 & 0.59 & 286.73 & 0.12 & 57.35 \\
\hline $\begin{array}{l}\text { State Park } \\
\text { Twin Lakes }\end{array}$ & TLG1 & 42.67 & 1 & 37.45 & 18350.42 & 7.49 & 3670.08 \\
\hline $\begin{array}{l}\text { State Park } \\
\text { Twin Lakes }\end{array}$ & TLG1 & 9.91 & 1 & 2.02 & 988.91 & 0.40 & 197.78 \\
\hline $\begin{array}{l}\text { State Park } \\
\text { Twin Lakes }\end{array}$ & TLG1 & 4.83 & 2 & 0.48 & 162.86 & 0.10 & 32.57 \\
\hline $\begin{array}{l}\text { State Park } \\
\text { Twin Lakes }\end{array}$ & TLG1 & 5.08 & 2 & 0.53 & 180.46 & 0.11 & 36.09 \\
\hline $\begin{array}{l}\text { State Park } \\
\text { Twin Lakes }\end{array}$ & TLG1 & 20.57 & 3 & 8.71 & 1305.85 & 1.74 & 261.17 \\
\hline $\begin{array}{l}\text { State Park } \\
\text { Twin Lakes }\end{array}$ & TLG1 & 12.19 & 3 & 3.06 & 458.57 & 0.61 & 91.71 \\
\hline $\begin{array}{l}\text { State Park } \\
\text { Twin Lakes }\end{array}$ & TLG1 & 24.38 & 4 & 12.23 & 1222.85 & 2.45 & 244.57 \\
\hline $\begin{array}{l}\text { State Park } \\
\text { Twin Lakes }\end{array}$ & TLG1 & 25.40 & 4 & 13.27 & 1326.88 & 2.65 & 265.38 \\
\hline $\begin{array}{l}\text { State Park } \\
\text { Twin Lakes }\end{array}$ & TLG1 & 5.59 & 4 & 0.64 & 64.22 & 0.13 & 12.84 \\
\hline $\begin{array}{l}\text { State Park } \\
\text { Twin Lakes }\end{array}$ & TLG1 & 10.67 & 4 & 2.34 & 234.06 & 0.47 & 46.81 \\
\hline State Park & TLG1 & 7.11 & 4 & 1.04 & 104.03 & 0.21 & 20.81 \\
\hline
\end{tabular}




\begin{tabular}{|c|c|c|c|c|c|c|c|}
\hline $\begin{array}{l}\text { Twin Lakes } \\
\text { State Park }\end{array}$ & TLG1 & 25.40 & 4 & 13.27 & 1326.88 & 2.65 & 265.38 \\
\hline $\begin{array}{l}\text { Twin Lakes } \\
\text { State Park }\end{array}$ & TLG2 & 11.43 & 1 & 2.69 & 1316.60 & 0.54 & 263.32 \\
\hline $\begin{array}{l}\text { Twin Lakes } \\
\text { State Park } \\
\text { Twin Lakes }\end{array}$ & TLG2 & 36.07 & 1 & 26.76 & 13110.04 & 5.35 & 2622.01 \\
\hline $\begin{array}{l}\text { State Park } \\
\text { Twin Lakes }\end{array}$ & TLG2 & 23.88 & 1 & 11.72 & 5744.91 & 2.34 & 1148.98 \\
\hline $\begin{array}{l}\text { State Park } \\
\text { Twin Lakes }\end{array}$ & TLG2 & 21.84 & 1 & 9.81 & 4808.66 & 1.96 & 961.73 \\
\hline $\begin{array}{l}\text { State Park } \\
\text { Twin Lakes }\end{array}$ & TLG2 & 6.60 & 1 & 0.90 & 439.52 & 0.18 & 87.90 \\
\hline $\begin{array}{l}\text { State Park } \\
\text { Twin Lakes }\end{array}$ & TLG2 & 54.36 & 1 & 60.77 & 29775.22 & 12.15 & 5955.04 \\
\hline $\begin{array}{l}\text { State Park } \\
\text { Twin Lakes }\end{array}$ & TLG2 & 8.13 & 2 & 1.36 & 461.97 & 0.27 & 92.39 \\
\hline $\begin{array}{l}\text { State Park } \\
\text { Twin Lakes }\end{array}$ & TLG2 & 8.38 & 2 & 1.44 & 491.29 & 0.29 & 98.26 \\
\hline $\begin{array}{l}\text { State Park } \\
\text { Twin Lakes }\end{array}$ & TLG2 & 10.92 & 2 & 2.45 & 834.16 & 0.49 & 166.83 \\
\hline $\begin{array}{l}\text { State Park } \\
\text { Twin Lakes }\end{array}$ & TLG2 & 13.46 & 2 & 3.73 & 1267.25 & 0.75 & 253.45 \\
\hline $\begin{array}{l}\text { State Park } \\
\text { Twin Lakes }\end{array}$ & TLG2 & 8.13 & 2 & 1.36 & 461.97 & 0.27 & 92.39 \\
\hline $\begin{array}{l}\text { State Park } \\
\text { Twin Lakes }\end{array}$ & TLG2 & 8.38 & 2 & 1.44 & 491.29 & 0.29 & 98.26 \\
\hline $\begin{array}{l}\text { State Park } \\
\text { Twin Lakes }\end{array}$ & TLG2 & 16.00 & 2 & 5.27 & 1790.57 & 1.05 & 358.11 \\
\hline $\begin{array}{l}\text { State Park } \\
\text { Twin Lakes }\end{array}$ & TLG2 & 16.51 & 2 & 5.61 & 1906.06 & 1.12 & 381.21 \\
\hline $\begin{array}{l}\text { State Park } \\
\text { Twin Lakes }\end{array}$ & TLG2 & 10.16 & 3 & 2.12 & 318.45 & 0.42 & 63.69 \\
\hline $\begin{array}{l}\text { State Park } \\
\text { Twin Lakes }\end{array}$ & TLG3 & 7.62 & 1 & 1.19 & 585.15 & 0.24 & 117.03 \\
\hline $\begin{array}{l}\text { State Park } \\
\text { Twin Lakes }\end{array}$ & TLG3 & 5.08 & 1 & 0.53 & 260.07 & 0.11 & 52.01 \\
\hline $\begin{array}{l}\text { State Park } \\
\text { Twin Lakes }\end{array}$ & TLG3 & 17.02 & 1 & 5.96 & 2918.62 & 1.19 & 583.72 \\
\hline $\begin{array}{l}\text { State Park } \\
\text { Twin Lakes }\end{array}$ & TLG3 & 10.41 & 1 & 2.23 & 1092.94 & 0.45 & 218.59 \\
\hline $\begin{array}{l}\text { State Park } \\
\text { Twin Lakes }\end{array}$ & TLG3 & 8.13 & 1 & 1.36 & 665.77 & 0.27 & 133.15 \\
\hline $\begin{array}{l}\text { State Park } \\
\text { Twin Lakes }\end{array}$ & TLG3 & 8.13 & 2 & 1.36 & 461.97 & 0.27 & 92.39 \\
\hline $\begin{array}{l}\text { State Park } \\
\text { Twin Lakes }\end{array}$ & TLG3 & 27.18 & 3 & 15.19 & 2278.72 & 3.04 & 455.74 \\
\hline $\begin{array}{l}\text { State Park } \\
\text { Twin Lakes }\end{array}$ & TLG3 & 27.18 & 3 & 15.19 & 2278.72 & 3.04 & 455.74 \\
\hline $\begin{array}{l}\text { State Park } \\
\text { Twin Lakes }\end{array}$ & TLG3 & 10.41 & 3 & 2.23 & 334.57 & 0.45 & 66.91 \\
\hline State Park & TLG3 & 21.34 & 4 & 9.36 & 936.25 & 1.87 & 187.25 \\
\hline 11-54-04 & $544 \mathrm{G} 2$ & 6.86 & 1 & 0.97 & 473.97 & 0.19 & 94.79 \\
\hline 11-54-04 & $544 \mathrm{G} 2$ & 39.37 & 1 & 31.88 & 15620.35 & 6.38 & 3124.07 \\
\hline $11-54-04$ & $544 \mathrm{G} 2$ & 16.51 & 1 & 5.61 & 2746.97 & 1.12 & 549.39 \\
\hline $11-54-04$ & $544 \mathrm{G} 2$ & 30.48 & 1 & 19.11 & 9362.46 & 3.82 & 1872.49 \\
\hline $11-54-04$ & $544 \mathrm{G} 2$ & 30.48 & 1 & 19.11 & 9362.46 & 3.82 & 1872.49 \\
\hline $11-54-04$ & 544G2 & 24.13 & 1 & 11.98 & 5867.79 & 2.40 & 1173.56 \\
\hline $11-54-04$ & $544 \mathrm{G} 2$ & 24.13 & 1 & 11.98 & 5867.79 & 2.40 & 1173.56 \\
\hline $11-54-04$ & $544 \mathrm{G} 2$ & 19.56 & 1 & 7.87 & 3854.86 & 1.57 & 770.97 \\
\hline 11-54-04 & $544 \mathrm{G} 2$ & 5.59 & 1 & 0.64 & 314.68 & 0.13 & 62.94 \\
\hline $11-54-04$ & $544 \mathrm{G} 2$ & 5.33 & 1 & 0.59 & 286.73 & 0.12 & 57.35 \\
\hline $11-54-04$ & $544 \mathrm{G} 2$ & 7.62 & 1 & 1.19 & 585.15 & 0.24 & 117.03 \\
\hline $11-54-04$ & $544 \mathrm{G} 2$ & 22.35 & 1 & 10.28 & 5034.92 & 2.06 & 1006.98 \\
\hline $11-54-04$ & $544 \mathrm{G} 2$ & 20.32 & 1 & 8.49 & 4161.09 & 1.70 & 832.22 \\
\hline $11-54-04$ & $544 \mathrm{G} 2$ & 5.33 & 1 & 0.59 & 286.73 & 0.12 & 57.35 \\
\hline $11-54-04$ & $544 \mathrm{G} 2$ & 5.59 & 1 & 0.64 & 314.68 & 0.13 & 62.94 \\
\hline
\end{tabular}




\begin{tabular}{|c|c|c|c|c|c|c|c|}
\hline $11-54-04$ & $544 \mathrm{G} 2$ & 5.08 & 2 & 0.53 & 180.46 & 0.11 & 36.09 \\
\hline $11-54-04$ & $544 \mathrm{G} 2$ & 5.84 & 2 & 0.70 & 238.65 & 0.14 & 47.73 \\
\hline $11-54-04$ & $544 \mathrm{G} 2$ & 5.08 & 2 & 0.53 & 180.46 & 0.11 & 36.09 \\
\hline $11-54-04$ & $544 \mathrm{G} 2$ & 18.29 & 3 & 6.88 & 1031.78 & 1.38 & 206.36 \\
\hline $11-54-04$ & $544 \mathrm{G} 2$ & 9.65 & 4 & 1.92 & 191.60 & 0.38 & 38.32 \\
\hline $11-55-25$ & $5525 \mathrm{G} 1$ & 15.49 & 1 & 4.94 & 2419.29 & 0.99 & 483.86 \\
\hline $11-55-25$ & $5525 \mathrm{G} 1$ & 9.65 & 1 & 1.92 & 938.85 & 0.38 & 187.77 \\
\hline $11-55-25$ & $5525 \mathrm{G} 1$ & 32.51 & 1 & 21.74 & 10652.40 & 4.35 & 2130.48 \\
\hline $11-55-25$ & $5525 \mathrm{G} 1$ & 15.75 & 1 & 5.10 & 2499.26 & 1.02 & 499.85 \\
\hline $11-55-25$ & $5525 \mathrm{G} 1$ & 16.51 & 1 & 5.61 & 2746.97 & 1.12 & 549.39 \\
\hline $11-55-25$ & $5525 \mathrm{G} 1$ & 5.33 & 1 & 0.59 & 286.73 & 0.12 & 57.35 \\
\hline $11-55-25$ & $5525 \mathrm{G} 1$ & 11.43 & 1 & 2.69 & 1316.60 & 0.54 & 263.32 \\
\hline $11-55-25$ & $5525 \mathrm{G} 1$ & 24.13 & 1 & 11.98 & 5867.79 & 2.40 & 1173.56 \\
\hline $11-55-25$ & $5525 \mathrm{G} 1$ & 6.35 & 1 & 0.83 & 406.36 & 0.17 & 81.27 \\
\hline $11-55-25$ & $5525 \mathrm{G} 1$ & 10.92 & 1 & 2.45 & 1202.17 & 0.49 & 240.43 \\
\hline $11-55-25$ & $5525 \mathrm{G} 1$ & 31.50 & 1 & 20.40 & 9997.03 & 4.08 & 1999.41 \\
\hline $11-55-25$ & $5525 \mathrm{G} 1$ & 9.65 & 1 & 1.92 & 938.85 & 0.38 & 187.77 \\
\hline $11-55-25$ & $5525 \mathrm{G} 1$ & 5.59 & 1 & 0.64 & 314.68 & 0.13 & 62.94 \\
\hline $11-55-25$ & $5525 \mathrm{G} 1$ & 15.75 & 1 & 5.10 & 2499.26 & 1.02 & 499.85 \\
\hline $11-55-25$ & $5525 \mathrm{G} 1$ & 25.91 & 1 & 13.80 & 6764.38 & 2.76 & 1352.88 \\
\hline $11-55-25$ & $5525 \mathrm{G} 1$ & 21.08 & 1 & 9.14 & 4479.03 & 1.83 & 895.81 \\
\hline $11-55-25$ & $5525 \mathrm{G} 1$ & 28.19 & 1 & 16.35 & 8010.75 & 3.27 & 1602.15 \\
\hline $11-55-25$ & $5525 \mathrm{G} 1$ & 31.75 & 1 & 20.73 & 10158.92 & 4.15 & 2031.78 \\
\hline $11-55-25$ & $5525 \mathrm{G} 1$ & 5.84 & 2 & 0.70 & 238.65 & 0.14 & 47.73 \\
\hline $11-55-25$ & $5525 \mathrm{G} 1$ & 12.19 & 2 & 3.06 & 1039.42 & 0.61 & 207.88 \\
\hline $11-55-25$ & $5525 \mathrm{G} 1$ & 7.62 & 2 & 1.19 & 406.02 & 0.24 & 81.20 \\
\hline $11-55-25$ & $5525 \mathrm{G} 1$ & 12.19 & 2 & 3.06 & 1039.42 & 0.61 & 207.88 \\
\hline $11-55-25$ & $5525 \mathrm{G} 1$ & 5.59 & 2 & 0.64 & 218.35 & 0.13 & 43.67 \\
\hline $11-55-25$ & $5525 \mathrm{G} 1$ & 5.59 & 2 & 0.64 & 218.35 & 0.13 & 43.67 \\
\hline $11-55-25$ & $5525 \mathrm{G} 1$ & 14.33 & 3 & 4.22 & 633.11 & 0.84 & 126.62 \\
\hline $11-55-25$ & $5525 \mathrm{G} 1$ & 21.34 & 3 & 9.36 & 1404.37 & 1.87 & 280.87 \\
\hline $11-55-25$ & $5525 \mathrm{G} 1$ & 9.65 & 3 & 1.92 & 287.40 & 0.38 & 57.48 \\
\hline $11-55-25$ & $5525 \mathrm{G} 1$ & 10.41 & 3 & 2.23 & 334.57 & 0.45 & 66.91 \\
\hline $11-55-25$ & $5525 \mathrm{G} 1$ & 8.89 & 3 & 1.63 & 243.81 & 0.33 & 48.76 \\
\hline $11-55-25$ & $5525 \mathrm{G} 1$ & 5.08 & 3 & 0.53 & 79.61 & 0.11 & 15.92 \\
\hline $11-55-25$ & $5525 \mathrm{G} 1$ & 18.29 & 4 & 6.88 & 687.85 & 1.38 & 137.57 \\
\hline $11-55-25$ & $5525 \mathrm{G} 1$ & 8.13 & 4 & 1.36 & 135.87 & 0.27 & 27.17 \\
\hline $11-55-25$ & $5525 \mathrm{G} 2$ & 9.65 & 1 & 1.92 & 938.85 & 0.38 & 187.77 \\
\hline $11-55-25$ & $5525 \mathrm{G} 2$ & 15.75 & 1 & 5.10 & 2499.26 & 1.02 & 499.85 \\
\hline $11-55-25$ & $5525 \mathrm{G} 2$ & 16.51 & 1 & 5.61 & 2746.97 & 1.12 & 549.39 \\
\hline $11-55-25$ & $5525 \mathrm{G} 2$ & 5.33 & 1 & 0.59 & 286.73 & 0.12 & 57.35 \\
\hline $11-55-25$ & $5525 \mathrm{G} 2$ & 11.43 & 1 & 2.69 & 1316.60 & 0.54 & 263.32 \\
\hline $11-55-25$ & $5525 \mathrm{G} 2$ & 6.35 & 1 & 0.83 & 406.36 & 0.17 & 81.27 \\
\hline $11-55-25$ & $5525 \mathrm{G} 2$ & 10.92 & 1 & 2.45 & 1202.17 & 0.49 & 240.43 \\
\hline $11-55-25$ & $5525 \mathrm{G} 2$ & 9.65 & 1 & 1.92 & 938.85 & 0.38 & 187.77 \\
\hline $11-55-25$ & $5525 \mathrm{G} 2$ & 5.59 & 1 & 0.64 & 314.68 & 0.13 & 62.94 \\
\hline $11-55-25$ & $5525 \mathrm{G} 2$ & 15.75 & 1 & 5.10 & 2499.26 & 1.02 & 499.85 \\
\hline $11-55-25$ & $5525 \mathrm{G} 2$ & 25.91 & 1 & 13.80 & 6764.38 & 2.76 & 1352.88 \\
\hline $11-55-25$ & $5525 \mathrm{G} 2$ & 21.08 & 1 & 9.14 & 4479.03 & 1.83 & 895.81 \\
\hline $11-55-25$ & $5525 \mathrm{G} 2$ & 28.19 & 1 & 16.35 & 8010.75 & 3.27 & 1602.15 \\
\hline $11-55-25$ & $5525 \mathrm{G} 2$ & 31.75 & 1 & 20.73 & 10158.92 & 4.15 & 2031.78 \\
\hline $11-55-25$ & $5525 \mathrm{G} 2$ & 12.19 & 2 & 3.06 & 1039.42 & 0.61 & 207.88 \\
\hline $11-55-25$ & $5525 \mathrm{G} 2$ & 7.62 & 2 & 1.19 & 406.02 & 0.24 & 81.20 \\
\hline $11-55-25$ & $5525 \mathrm{G} 2$ & 12.19 & 2 & 3.06 & 1039.42 & 0.61 & 207.88 \\
\hline $11-55-25$ & $5525 \mathrm{G} 2$ & 5.59 & 2 & 0.64 & 218.35 & 0.13 & 43.67 \\
\hline $11-55-25$ & $5525 \mathrm{G} 2$ & 5.59 & 2 & 0.64 & 218.35 & 0.13 & 43.67 \\
\hline $11-55-25$ & $5525 \mathrm{G} 2$ & 8.89 & 3 & 1.63 & 243.81 & 0.33 & 48.76 \\
\hline $11-55-25$ & $5525 \mathrm{G} 2$ & 5.08 & 3 & 0.53 & 79.61 & 0.11 & 15.92 \\
\hline $11-55-25$ & $5525 \mathrm{G} 2$ & 18.29 & 4 & 6.88 & 687.85 & 1.38 & 137.57 \\
\hline $11-55-25$ & $5525 \mathrm{G} 2$ & 8.13 & 4 & 1.36 & 135.87 & 0.27 & 27.17 \\
\hline
\end{tabular}

